\title{
UNIVERSITYOF
}

FORWARD

THINKING

WESTMINSTER用

WestminsterResearch

http://www.westminster.ac.uk/westminsterresearch

Communication in the Gig Economy: Buying and Selling in

Online Freelance Marketplaces

Urwin, P. and Ludwig, S.

This is a copy of the accepted author manuscript of the following article: Urwin, P. and Ludwig, S. 2021. Communication in the Gig Economy: Buying and Selling in Online Freelance Marketplaces. Journal of Marketing. The final definitive version will be available from the publisher Sage at:

https://journals.sagepub.com/home/imx

(C) The Author(s) 2021

The WestminsterResearch online digital archive at the University of Westminster aims to make the research output of the University available to a wider audience. Copyright and Moral Rights remain with the authors and/or copyright owners. 


\section{JOURNAL of Marketing}

Communication in the Gig Economy: Buying and Selling in Online Freelance Marketplaces

\begin{tabular}{|r|l|}
\hline Journal: & Journal of Marketing \\
\hline Manuscript ID & JM.19.0542.R4 \\
\hline Manuscript Type: & Revised Submission \\
\hline Research Topics: & B2B Marketing, Marketing Communications, Digital Marketing - Firms \\
\hline Methods: & Panel Data Models, Regression Models, Text Mining \\
\hline \multicolumn{2}{|l}{} \\
\end{tabular}

\section{SCHOLARONE \\ Manuscripts}




\title{
Communication in the Gig Economy: Buying and Selling in Online Freelance Marketplaces
}

\author{
Abstract \\ The proliferating gig economy relies on online freelance marketplaces, which support relatively \\ anonymous interactions by text-based messages. Informational asymmetries thus arise that can \\ lead to exchange uncertainties between buyers and freelancers. Conventional marketing thought \\ recommends reducing such uncertainty. However, uncertainty reduction and uncertainty \\ management theories indicate that buyers and freelancers might benefit more from balancing, \\ rather than reducing, uncertainty, such as by strategically adhering to or deviating from common \\ communication principles. With dyadic analyses of calls for bids and bids from a leading online \\ freelance marketplace, this study reveals that buyers attract more bids from freelancers when \\ they provide moderate degrees of task information and concreteness, avoid sharing personal \\ information, and limit the affective intensity of their communication. Freelancers' bid success \\ and price premiums increase when they mimic the degree of task information and affective \\ intensity exhibited by buyers. However, mimicking a lack of personal information and \\ concreteness reduces freelancers' success, so freelancers should always be more concrete and \\ offer more personal information than buyers do. These contingent perspectives offer insights into \\ buyer-seller communication in two-sided online marketplaces; they clarify that despite, or \\ sometimes due to, communication uncertainty, both sides can achieve success in the online gig \\ economy. \\ Keywords: online freelance marketplaces, gig economy, multi-sided platforms, business-to- \\ business exchange, uncertainty management, text analysis
}


Online freelance marketplaces, such as Upwork, Fiverr, and PeoplePerHour, have already prompted massive transformations in business-to-business (B2B) markets (Constantinides, Henfridsson, and Parker 2018; Zhou et al. 2021). In particular, they allow buyers to post gigs, or short-term service projects, which initiate reverse auctions in which interested freelance workers submit bids to offer their services (Jap 2007). In these digital environments, buyers and freelancers often devote rather limited time and attention to detailed assessments and instead make choices on the basis of rational value expectations or prices (Ba and Pavlou 2002; Rajdeep et al. 2015). In addition, online freelance marketplaces suffer information asymmetries, because they rely on text-based messages, which can create uncertainty and hinder the exchange (Hong, Wang, and Pavlou 2016; Srivastava and Chandra 2018). Imagine a buyer wants to hire a freelancer to optimize its pet website's search rankings, so it posts a call for bids, requesting "someone for an SEO job." In response, Freelancer A might vaguely promise, "I have plenty of experience writing content that users find interesting to improve the quality and quantity of your traffic," whereas Freelancer B more concretely states, "I have four years of experience writing articles and blogs that engage users and are SEO friendly. For example, I could focus on interest pieces like the everyday lives of pets." The buyer and the freelancers' communication create different degrees of uncertainty; likely impacting who applies and who gets hired.

Uncertainty regarding communication can lead to various negative outcomes on both sides, including high rates (more than 50\%) of service gigs that go unfulfilled (Horton 2019), diminished bid success, or less-than-optimal pricing for freelancers (Ba and Pavlou 2002). Yet in general, parties to B2B exchanges also leverage uncertainty in their communication strategically to achieve more effective outcomes, such as when negotiators conceal information (Putman and Jones 1982) or ambiguous contracts help reduce litigation concerns and increase cooperation 
(Zheng et al. 2020). Buyers and freelancers on online freelance marketplaces engage in a form of B2B exchange, so we propose that they similarly might balance their communication efforts by reducing and increasing uncertainty strategically to maximize their exchange success. In our previous example, by staying vague and without any specific direction from the buyer, Freelancer A might be trying to keep multiple options open and avoid overpromising outcomes.

In addition to fundamental questions regarding how to manage uncertainty in B2B exchanges (Lawrence et al. 2019; Palmatier, Dant, and Grewal 2007), we seek to address the role of communication in such exchanges (Berger et al. 2020; Rajdeep et al. 2015; see also Web Appendices A and B). We integrate uncertainty reduction theory (Berger and Calabrese 1975) and uncertainty management theory (Brashers 2001) to predict that, in online freelance markets, various strategies for reducing and increasing the ability of message recipients to anticipate message senders' meaning and actions can benefit the exchange (Bradac 2001). Using Grice's (1975) communication principles, we argue that greater provision of task and personal information might reduce uncertainty in service exchanges (Ma and Dubé 2011) but also could relate to information overload or disagreements (Eisenberg and Witten 1987; Jones, Ravid, and Rafaeli 2004). Presenting information in a more concrete (cf. abstract) manner or with greater affective intensity also can reduce uncertainty (Grice 1975; Hamilton and Hunter 1998; Packard and Berger 2020). But again, too much concreteness or affective intensity might lead to restrictive communication that hinders exchanges (Eisenberg and Witten 1987; Hosman 2002).

We apply this theoretical reasoning to exchanges in online freelance marketplaces, in which buyers post calls for bids to attract as many freelancers as possible to apply (Horton 2019). These buyers face a trade-off, between reducing uncertainty for freelancers (e.g., provide more information, use less ambiguity) and still efficiently granting them sufficient interpretative 
freedom. Theorists concur that principles for using relevant information or unambiguously often get deliberately flouted in conversation, such as to save face (Goffman 2008) or please a counterpart (Khosarvizadeh and Sadehvandi 2011). If different communication strategies might entice more freelancers to bid, we could establish optimal designs for the calls for bids.

In response to those calls for bids, freelancers write and submit their bids. In doing so, these freelancers also must manage uncertainty. Thus, they might benefit from matching or mimicking the communication approach adopted by the prospective buyer that issued the call (Verbeke, Dietz, and Verwaal 2011). Communicative mimicry can evoke similarity perceptions, which tend to increase receivers' sense of rapport and reduce their uncertainty (Soliz and Giles 2014). Research on adaptive selling recommends matching the buyer's communication (e.g., McFarland, Challagalla, and Shervani 2006; Singh, Marinova, and Singh 2020). Yet in some situations, deviations also may be beneficial (Afifi and Burgoon 2000), so we consider a more nuanced distinction, related to the level at which the similarity occurs. Furthermore, if freelancers compete on price, they may become enmeshed in a self-defeating value trap (Hong, Wang, and Pavlou 2016; Sridhar and Mittal 2020): They win more bids but earn less revenue. Strategically mimicking or deviating from a buyer's communication might provide a viable means to win more gigs without being trapped. We accordingly suggest how freelancers should calibrate their bid formulations to improve their bid success and achieve a price premium.

Using a unique, large-scale data set of calls for bids and bids, obtained from a leading online freelance marketplace, along with a series of multilevel models that account for endogeneity, we establish three main contributions. First, we determine the effects of buyers' strategic communication in two-sided online marketplaces (Berger et al. 2020). Rather than uncritically recommending that communication should always be informative and unambiguous, 
we specify the diminishing, even adverse consequences that can result if buyers relay too much task or personal information in a very concrete, intense manner. Second, in an extension of research into adaptive selling (McFarland, Challagalla, and Shervani 2006; Verbeke, Dietz, and Verwaal 2011), we reveal how freelancers' dyadic communicative mimicry affects bid success. Mimicry effects are contingent on the communicative aspect and the buyer's relative uses of each aspect. As we show, mimicking buyers in terms of the provision of task information and use of affective intensity increases bid success. In contrast, we find that freelancers should always offer more personal information and be more concrete in their bid formulations than buyers' calls for bids are. Third, we offer insights into how freelancers can avoid predatory pricing (Constantinides, Henfridsson, and Parker 2018) and escape a value trap (Sridhar and Mittal 2020). By strategically managing uncertainty according to the information communicated, and the manner they use to do so, they can earn price premiums.

\section{Online Freelance Marketplace Exchanges}

Online freelance marketplaces that feature reverse auctions rely on a three-stage process (Hong, Wang, and Pavlou 2016; Jap 2007). First, in seeking a suitable freelancer, a buyer describes a gig or short-term service project in a call for bids. Second, multiple freelancers apply, by formulating and submitting bids that describe themselves, the service offering, and the price requested. Third, the buyer compares the bids and selects a freelancer to complete the gig. The outcome of each stage defines exchange success. That is, buyers' success results from a large pool of viable freelance offers; a higher number of bids increase the chances of finding a suitable freelancer for the gig (Horton 2017, 2019). Freelancers' success depends on whether their bids are chosen, preferably at a price premium (Hong and Pavlou 2017; Constantinides, Henfridsson, and Parker 2018). In this context, a price premium is the monetary amount in excess of the 
buyer's original payment offer (i.e., expected price; Grewal, Monroe, and Krishnan 1998; Singh and Sirdeshmukh 2000). Buyers might pay a premium beyond their original payment offer for various reasons, including their willingness or "need to compensate the seller for reducing transaction risks" (Ba and Pavlou 2002, p. 248). In competitive online markets, freelancers also might encounter value traps, such that they wind up selling more of their services at a lower price (Ba and Pavlou 2002; Sridhar and Mittal 2020). In this sense, freelancers' success depends on winning the bid but also earning price premiums (or avoiding discounts). Unlike traditional B2B exchanges, buyers' and freelancers' success hinge on textual communication (Constantinides, Henfridsson, and Parker 2018; Horton 2019). Comparing theories on uncertainty and the role of communication in producing or reducing it, we delineate how both buyers and freelancers may best strike a balance between providing more information and reducing ambiguity versus preserving some uncertainty and maintaining interpretative flexibility.

\section{Conceptual Background}

Uncertainty reduction theory (Berger and Calabrese 1975) and uncertainty management theory (Brashers 2001) draw on a central tenet of information theory (Shannon and Weaver 1949), namely, that communication, information, and uncertainty are inextricably linked. Thus, uncertainty is inherent to any interaction. Goffman (1959) suggests uncertainty depends on the ability to draw inferences from provided information content and the manner in which it is provided. Whereas uncertainty reduction theory predicts how communication can reduce uncertainty, uncertainty management theory examines how people cope with uncertainty, which may include efforts to increase uncertainty to attain beneficial outcomes (Bradac 2001). Our conceptual development relies on these fundamental principles. 


\section{Communication Principles in Online Freelance Marketplaces}

In online freelance marketplaces, buyers and freelancers depend on one another; all else being equal, they want their mutual exchange to succeed. In such interactions, Grice (1975) suggests that four generalized cooperative communication principles (or maxims) apply. Three principles refer to what should be said: the quantity of information ("give as much information as is required, and no more than is required"), its quality ("do not say what is false or that for which you lack adequate evidence"), and its relevance. Then the fourth principle, manner (be clear and avoid ambiguity), pertains to "how what is said is to be said" (Grice 1975, p. 46). In our study context, neither a buyer nor a freelancer can know upfront whether the other party might be lying, so truthfulness would have to be assumed prior to the exchange. We also highlight that information does not have to be "correct" to influence uncertainty perceptions (Brashers 2001). Therefore, among the four maxims, we focus on the quantity of relevant information that buyers and freelancers offer and the manner in which they present it.

\section{Uncertainty Implications of Communication Principles}

Communication outcomes are fundamentally uncertain (Berger and Calabrese 1975). When people vary their use of communication principles (Grice 1975), they create conversational implications, such that message recipients must infer what speakers are trying to imply with their wording. Accordingly, the (un)certainty that buyers and freelancers encounter while making inferences should depend on the degree to which call for bids and bids provide relevant information in an unambiguous manner, though the meaning of relevant information varies by context. In line with prior research (e.g., Berger et al. 2020), we define this degree as the proportion of specific lexical terms used, relative to the total number of words in a message. 
More information reduces uncertainty (Berger and Calabrese 1975) and increases receivers' perceptions of its value (Weiss, Lurie, and MacInnis 2008). In service exchanges, the parties seek information about the task and the person who will complete it (Ma and Dubé 2011). A greater degree of task information should reduce uncertainty about functional service aspects (Ma and Dubé 2011). By self-disclosing greater degrees of personal information, a sender also provides a receiver with more information about the self (Derlega, Harris, and Chaikin 1973). In line with the quantity principle (Grice 1975), sparse provision of relevant task and personal information would make it difficult for the receiver to anticipate outcomes or distinguish among options, thus creating uncertainty (Engelhardt, Bailey, and Ferreira 2006).

Regarding the principle of manner (Grice 1975), greater degrees of concreteness and affective intensity should reduce ambiguity and enhance clarity. Concrete terms describe something in a perceptible, precise, specific, or clear manner (Brysbaert, Warriner, and Kuperman 2014; Larrimore et al. 2011; Packard and Berger 2020). A greater degree of concreteness reduces ambiguity because it makes it easier for receivers to perceive or recognize what it is that the message sender is implying (Brysbaert, Warriner, and Kuperman 2014; Hamilton and Hunter 1998; Packard and Berger 2020). Affective intensity instead reflects the proportion of affective terms included in a message (Hamilton, Hunter, and Burgoon 1990). More affective terms, as a proportion of the total word count, produces a greater degree of affective intensity, which increases receivers' ability to make evaluative judgments (Hamilton and Hunter 1998; Hosman 2002). ${ }^{1}$ We provide examples of these principles in table 1.

\footnotetext{
${ }^{1}$ Task and personal information, concreteness, and affective intensity do not comprise an exhaustive list of all the lexical elements that might define relevant information content and communication manners. Various extensions are thus available for further research. However, we note the primacy of these elements in previous research and therefore prioritize them for this initial effort to establish how the communication principles relate to uncertainty perceptions and exchange outcomes in online freelance marketplaces.
} 
[please insert Table 1 here]

\section{Reducing and Maintaining Uncertainty in Communication Exchanges}

Cross-disciplinary research provides ample evidence that conversational partners generally prefer to reduce uncertainty (Berger 2011). In B2B relationships, reducing uncertainty increases exchange effectiveness (Heide and Weiss 1995; Lawrence et al. 2019; Palmatier, Dant, and Grewal 2007). In online, freelance, relatively anonymous marketplaces specifically, the required coordination and dependence by rational buyers and freelancers may increase their need for information and clarity (Constantinides, Henfridsson, and Parker 2018; Hong, Wang, and Pavlou 2016). Thus for example, reputation cues commonly appear in online freelance markets, as a way to reduce uncertainty and facilitate exchanges (Hong, Wang, and Pavlou 2016). More broadly, reducing uncertainty by adhering to Grice's (1975) principles in dyadic, buyer-freelancer communications may boost exchange success.

However, people experience uncertainty differently and do not always prefer to reduce it (Bradac 2001). Instead, according to uncertainty management theory (Brasher 2001), strategic communication choices that might not minimize uncertainty, and even cultivate it, can be effective and lead to better outcomes for consumers (Humphreys, Isaac, and Wang 2020), organizations (Eisenberg and Witten 1987; Homburg, Klarmann, and Staritz 2012), and interorganizational governance (Zheng et al. 2020). For example, Humphreys et al. (2020) find that a lack of concreteness aids consumers' initial online searches, because such vague queries return a greater variety of search results. In collective bargaining settings, seasoned negotiators use concealment and ambiguity to enhance the likelihood of agreement (Putnam and Jones 1982). In B2B exchanges, parties can use less information and more ambiguity strategically to accomplish specific goals (Bayer, Tuli, and Skiera 2017; Zheng et al. 2020). Even if such efforts 
are not universally favored, uncertainty-cultivating communication provides benefits by allowing for multiple, simultaneous meanings, as understood by different receivers (Eisenberg and Witten 1987). Moreover, communication theorists concur that people sometimes deliberately flout or violate Grice's (1975) conversation principles, such as when they intentionally maintain uncertainty to save face (Goffman 2008) or please a counterpart (Khosarvizadeh and Sadehvandi 2011). Subverting the principles is not necessarily less cooperative; furthermore, the purpose of communication is not always to be as informative and clear as possible. Arguably, cooperative principles encourage reasonable adherence, not compulsion. Thus, strategically allowing recipients to develop a broader range of possible interpretations, by maintaining some level of uncertainty, might facilitate buyer-freelancer exchanges.

\section{Research Propositions}

\section{Managing Freelancers' Uncertainty in Calls for Bids}

Freelancers choose whether to offer their services in response to a buyer's call for bids. The number of freelancers who choose to do so is consequential for the buyer, because more bids implies a greater likelihood of finding a suitable service provider (Horton 2019). Managing freelancers' uncertainty through relevant information provision and the manner of communication in the calls for bids should influence freelancers' decisions to apply.

Relevant information. In calls for bids, buyers can vary the degree of task and personal information included in the description of the gig. If freelancers evaluate this information favorably, they develop more positive dispositions and are more likely to apply (Singh, Marinova, and Singh 2020). As prior research establishes, more information enhances communication outcomes in business settings, by reducing uncertainty. For example, studying web forums, Weiss, Lurie, and MacInnis (2008) indicate that the breadth of information provided 
by a sender affects receivers' objective judgments of the value of that information. Larrimore et al. (2011) find that greater degrees of monetary information increase peer-to-peer lending, and Joshi (2009) shows that more task information increases the time and commitment sellers allocate to a buyer. Greater degrees of personal information also reduce uncertainty, increase trust (Ma et al. 2017), and enhance performance on crowdsourcing platforms (Pollock, Luttgens, and Pillar 2019). Such self-disclosure can strengthen ongoing buyer-seller relations too (Crosby, Evans, and Cowles 1990). In contrast, a greater proportion of non-relevant information (i.e., lesser degree of relevant information) increases uncertainty (Brashers 2001). Because greater degrees of task and personal information in calls for bids help reduce freelancers' uncertainty, freelancers who believe they qualify should be more willing to submit bids.

Excessive relevant information may be ineffective however, even if it reduces freelancers' uncertainty. That is, if buyers provide excessive details about the task, the gig may appear too restrictive or prescriptive (Eisenberg and Witten 1987), which might not appeal to freelancers. For example, leaving detailed information out of contracts (Ghosh and John 2005) or negotiations (Putman and Jones 1982) represents a tactic to improve exchange performance. In a downsizing context, a greater degree of information provision can increase uncertainty and negative reactions (Homburg, Klarmann, and Staritz 2012). For freelancers, excessive information can feel overwhelming and limit their motivation, opportunity, or ability to process the information and submit bids (Jones, Ravid, and Rafaeli 2004). A buyer that self-discloses a lot of personal information also might appear less attractive as a prospective business contact (Collins and Miller 1994). Because extensive self-disclosures are unusual in initial B2B online exchanges (Koponen and Rytsy 2020), they might be perceived as inappropriate (Moon 2000). 
In summary, we argue that moderate degrees of task and personal information in calls for bids relate to more bids by freelancers. Buyers who provide greater degrees of task and personal information should attract more bids, but beyond a moderate degree (i.e., very dense provision of relevant information), providing still greater degrees of task and personal information may decrease the number of bids. We thus propose a curvilinear relationship.

$\mathbf{P}_{\mathbf{1}}$ : Extremely sparse and extremely dense degrees of (a) task and (b) personal information in calls for bids yield fewer freelance bids than do moderate degrees.

Communication manner. In calls for bids, buyers can vary the concreteness and affective intensity with which they describe the gig. Researchers disagree about whether more or less ambiguous communication leads to more efficacious speech (Bradac 2001; Eisenberg and Witten 1987; Hosman 2002), but in an online freelance marketplace, we posit that buyers must reduce ambiguity to at least some extent, by being more concrete and intense. Greater concreteness and affective intensity can be more efficient, because recipients can process the information with less time and effort (Hosman 2002, Packard and Berger 2020). Their use also tend to be more persuasive, memorable, and accessible than communication that uses predominantly abstract or unemotional wording (Hosman 2002; Hamilton and Hunter 1998). In other settings, greater concreteness increases consumer satisfaction with employee interactions and purchase likelihood (Packard and Berger 2020). Greater degrees of intensity, achieved through proportionally more affective words, provide accessible, diagnostic signals to customers (Ludwig et al. 2013). As a form of inspirational appeals, they can sway business partners' decisions too (Singh, Marinova, and Singh 2020). Finally, greater concreteness and affective intensity provide heuristic cues, so freelancers can take mental shortcuts, which makes them more likely to bid (Hosman 2002).

However, if the calls for bids appear too concrete or too intense, the task might appear narrow which reduces the appeal of performing the gig (Hosman 2002). Williams (1980) finds 
that greater vagueness (cf. less concreteness) can enhance judgments of a speaker's character, message acceptance, and recall. Moreover, some research asserts that reducing uncertainty with more concrete formulations is ineffective (Brashers 2001; Eisenberg and Witten 1987), so managers instead should embrace strategic ambiguity to allow for interpretative freedom (Keleman 2000). In contracts, unexpected specificity even increases ex ante costs (Mooi and Ghosh 2010). Greater task ambiguity instead can lower costs, as well as reduce the risk of litigation and enhance cooperation in B2B exchanges (Zheng et al. 2020). Greater degrees of concrete terms in communications with investors also can have adverse effects (Pan et al. 2018), and excessive degrees of positive affective words diminish the impact of customer reviews (Ludwig et al. 2013). Thus, we predict a stylistic trade-off: Overly ambiguous calls for bids, lacking any concreteness or affective intensity, may undercut buyers' success in attracting freelancers, but some degree of ambiguity (i.e., avoiding overly concrete, affectively intense communication) can allow for divergent interpretations to coexist. Thus, moderate degrees of concreteness and affective intensity may be most effective in encouraging freelancers to bid.

$\mathbf{P}_{2}$ : Extremely sparse and extremely dense degrees of (a) concreteness and (b) affective intensity in calls for bids yield fewer freelance bids than do moderate degrees.

\section{Managing Buyers' Uncertainty in Bids}

Buyers also face uncertainty when deciding whom to hire and how much to pay (Ba and Pavlou 2002; Constantinides, Henfridsson, and Parker 2018). By managing these uncertainties through their bids, freelancers can affect their chances of winning bids and their price premiums. To establish relevant predictions, we integrate Grice's (1975) communication principles with uncertainty research, such that we anticipate that a greater provision of relevant information, communicated with greater concreteness and affective intensity, allows buyers to draw inferences from freelancers' bids with more certainty. Beyond these communication principles, 
Berger and Calabrese (1975) suggest that perceived similarity to a message sender reduces receivers' uncertainty. Thus, both purchase likelihood and buyers' willingness to pay a price premium might be influenced by freelancers' adherence to certain communication principles, as well as by their communicative similarity to the buyer.

Winning bids. In other exchange contexts, research has established that greater degrees of service or personal information (Liu et al. 2015, Packard, Moore, and McFarran 2018) that service employees relay, improve customers' intentions to purchase. Willingness to purchase also increases if employees use greater concreteness in online service chats (Packard and Berger 2020) or greater degrees of affective words in their emails (Singh, Marinova, and Singh 2020).

However, the dense provision of relevant information in a bid risks information overload (Jones, Ravid, and Rafaeli 2004), and being overly concrete or intense might signal a restrictive, narrow approach to the gig (Hosman 2002). Our reasoning here parallels that for the buyers' call for bids formulations. We thus similarly predict that moderate degrees of task and personal information, provided in a moderately unambiguous manner (i.e., moderate degrees of concreteness and affective intensity), enhance freelancers' chances of winning the gig.

Yet preferences for uncertainty also might be situational and dispositional (Brashers 2001), as reflected in buyers' own communicative choices (Holtgraves 1997). Specifically, calls for bids can reveal buyers' expectations and preferences for communication behaviors. For example, buyers might like to get to know freelancers or prefer to keep their business relationships impersonal. The extent to which they disclose their own personal information in calls for bids should signal these preferences. An ambiguous bid offered in response to an ambiguous call for bids might lead the buyer to conclude that the freelancer is tactful, sensitive, and non-coercive (Brown and Levinson 1987). Adaptive communications also raise perceptions of credibility, 
common social identity, approval, and trust (Ludwig et al. 2013; Soliz and Giles 2014), as well as similarity perceptions, which in turn reduce uncertainty (Berger and Calabrese 1975). Crafting responses that mimic the buyer's communication is a common personal selling recommendation (Verbeke, Dietz and Verwaal 2011). As Singh, Marinova, and Singh (2020) show, when sellers mimic buyers' communicative manner, it increases buyers' attention. Accordingly, freelancers who mimic a buyer's communication content and manner might improve their exchange success.

In some situations, though, deviating from buyers' communication may be more beneficial (Afifi and Burgoon 2000). Even in studies that note the performance benefits of adaption, researchers highlight the importance of the degree of adaptivity (e.g., degree to which sales behaviors adjust for each customer during the interaction; Verbeke, Dietz, and Verwaal 2011). Similarly, studies of communication accommodation investigate the degree of accommodation used (Soliz and Giles 2014). Extending these insights, the outcomes of adaptation likely depend on communication levels (e.g., very informative vs. not informative); in keeping with uncertainty reduction theory, we expect that buyers are less likely to hire freelancers whose bids offer sparse information and are very ambiguous, even if the call for bids has these characteristics.

$\mathbf{P}_{\mathbf{3}}$ : When the degrees of (a) task and (b) personal information, (c) concreteness, and (d) affective intensity provided by the buyer are at least moderate (sparse), freelancers can increase (decrease) their chances of bid success by mimicking buyers' communication.

Achieving price premiums. Buyers' uncertainty about a freelancer should influence their willingness to pay a price premium (Ba and Pavlou 2002). Although there are many reasons for price variations (Grewal, Monroe, and Krishnan 1998), in online freelance marketplaces, buyers compensate (penalize) freelancers for reducing (increasing) their transaction uncertainty by deciding to accept a price above (below) their original payment offer (Ba and Pavlou 2002). In line with Rao and Monroe (1996), freelancers' greater provision of relevant task and personal 
information in a more concrete and intense manner in bids likely reduces buyers' information asymmetry and exchange-specific risks. Therefore, buyers who want to transact with high certainty may render a price premium for such bids (Liu et al. 2015).

The degree to which freelancers mimic buyers' communication also may influence the price premium. For example, Mullins, Agnihotri, and Hall (2020) find that adaptive approaches for different customers help salespeople increase those customers' willingness to pay a price premium. However, in line with our arguments regarding bid success, we expect that the positive influence of mimicry depends on the specific level of the communication element that the buyer uses. This reasoning aligns conceptually with the communication principles (Grice 1975), the recommendation that uncertainty should be carefully managed (Bradac 2001), and the benefits of mimicry identified in studies of communication accommodation (Soliz and Giles 2014) and adaptive selling (Verbeke, Dietz, and Verwaal 2011). However, we know of no studies that consider price premium implications of communicative trade-offs between reducing buyers' uncertainty and adapting to buyers' communication. In addition, we are not aware of any research that considers the possible negative effects when sellers mimic buyers who provide lesser task and personal information, are less concrete, or sparsely use affective intensity. Buyers who want to transact with high certainty might render a price premium to freelancers who reduce their uncertainty by providing greater degrees of relevant information, in a more concrete and intense manner. But if buyers perceive that these provisions of relevant information, degrees of concreteness, and intensity surpass their own reasonable level, they might feel overloaded or restricted and thus be unwilling to pay a premium. We thus predict that buyers offer a price premium to freelancers who provide degrees of relevant information, 
concreteness, and affective intensity similar (but never too sparse) to their own communication manner, because only these bids help reduce buyers' exchange risks.

$\mathbf{P}_{4}$ : When the degrees of (a) task and (b) personal information, (c) concreteness, and (d) affective intensity provided by the buyer are at least moderate (sparse), freelancers can increase (decrease) their chances of earning a price premium by mimicking the communication of the buyer.

Figure 1 presents the propositions, including predictions about the success of buyers' calls for bids (i.e., number of freelancers attracted, at Stage 2 of the biding process) and the success of freelancers' bids (i.e., chances of winning and obtaining a price premium, Stage 3).

[please insert Figure 1 here]

\section{Field Study of an Online Freelance Marketplace}

\section{Setting and Sample}

We conducted a large-scale field study with a proprietary data set of calls for bids and corresponding bids, posted on a leading, global online freelance marketplace. The hosts seven freelance service submarkets: (1) design, (2) writing \& translation, (3) video, photo, \& audio, (4) business support, (5) social media, sales, \& marketing, (6) software \& mobile development, and (7) web development. As Figure 1 illustrates, the bidding process follows a sequential, sealed-bid reverse auction format, and it concludes when the buyer chooses one winning bid (Hong, Wang, and Pavlou 2016; Jap 2007). We use text data from 343,796 calls for bids issued by 49,081 buyers (restricted to those who posted at least two gigs) to predict buyers' call for bids success, 2,327,216 bids submitted by 34,851 freelancers (restricted to those who submitted at least two bids) to predict freelancers' bid success, and 148,158 bids submitted by 30,851 freelancers (restricted to those who won and for which the payment was disclosed) to predict freelancers' price premium. Our multilevel approach requires more than one observation (call for bid or bid) in each level 2 unit (buyer or freelancer); otherwise, level 2 and level 1 variance might be 
confounded (Snijders and Bosker 2011). Web Appendix C summarizes the definitions and operationalizations and Web Appendix $\mathrm{J}$ the descriptive statistics and correlations.

\section{Measurement of Constructs}

The number of freelancers who submit bids to offer their services provides the measure of the success of buyers' call for bids. More submitted bids increase the probability that buyers can find an appropriate freelancer, whereas failing to find a suitable match is time consuming and costly, because it requires further searches and delays the project (Horton 2017, 2019). We measure freelancers' bid success as a binary indicator of whether (1) or not (0) the freelancer is chosen by the buyer and wins the bid (Hong and Pavlou 2017). For freelancers' price premium, we gauge the percentage by which the accepted bid price for the project exceeds (or falls short of) the buyer's original payment offered (i.e., benchmark price; Farris et al. 2010). This operationalization accounts for the difference between the final price a buyer pays and the original price she offered (i.e. what the buyer expected to pay) (Singh and Sirdeshmukh 2000).

To capture the independent communication variables, we mined the text of each call for bid and each bid. For the preprocessing and extraction steps, we used the R package Quanteda (Benoit et al. 2018), as well as a combination of newly developed and prevalidated text mining dictionaries. For the degree of task information in each text, we inductively sourced a list of context-specific task descriptor words. To start, we acquired all 34,851 freelancers' service skill tags (Berger et al. 2020; for an illustration, see Web Appendix D), which freelancers list in their profiles to describe the service tasks they offer (e.g., "developer," "illustrator"). After removing stop words and duplicates, two coders reviewed the remaining word list, deleted any misspelled words, and removed terms that did not describe a service (e.g., "great," "reliable"). Using Quanteda (Benoit et al. 2108), we stemmed the remaining words, leaving 1,912 unique word 
stems that describe service tasks. We mined each call for bids and bid and summed word occurrences reflecting the new task dictionary. By dividing this sum by total words, we obtain a measure of the degree (ratio) of task information in each text. When people self-disclose personal information, they use singular, first-person pronouns. In line with previous research (e.g., Pennebaker and Stone 2003), we measure the degree of personal information as the ratio of first-person singular pronoun words (e.g., "I," "me") to the total words in each text. To determine the degree of communication concreteness, we mined each text for Brysbaert, Warriner, and Kuperman's (2014) list of generally known English lemmas that indicate whether a concept denoted by a term refers to a perceptible entity. Following their operationalization, we include all terms that receive a rating of 3 or greater on their bipolar, 5-point abstract-to-concrete rating scale. ${ }^{2}$ That is, terms that score 3 or higher refer to relatively more specific objects, materials, people, processes, or relationships. We again divide the sum of the concrete terms by the total words in each text. Finally, the ratio of emotion-laden words (e.g., "problematic," "easy"; Hamilton and Hunter 1998; Hosman 2002) determines affective intensity. From the LIWC affect dictionary, we obtain a list of affect words, which we sum for each text (Pennebaker et al. 2015), then divide by the total word count to obtain the degree of affective intensity.

\section{Pilot Studies}

Validity of text-mined measures. To ensure the validity of our text-mined communication measures, we asked two coders to classify the texts of a random subsample of 100 calls for bids $\left(\mathrm{M}_{\text {length }}=129\right.$ words $)$ and 100 bids $\left(\mathrm{M}_{\text {length }}=102\right.$ words $)$. The coders indicated if considerable task information, personal information, concreteness, and affective intensity were present in each

\footnotetext{
${ }^{2}$ More stringent term lists, using cut-off levels at 3.5 or 4 , strongly correlate $(\mathrm{r}>.60, p<.01)$ with the list that uses 3 as a cut-off.
} 
text(1); or not (0). Comparing the coders' classifications with our text-mined classification revealed substantial agreement, for both calls for bids (.73 to .94$)$ and bids (.66 to .88) (Krippendorff 2013). The average F1 measure is sufficiently high for both bids (.79 to .95) and calls for bids (.80 to .95), as we detail in Web Appendix F.

Experimental evidence of uncertainty reduction. To establish the internal validity of the chosen communication aspects on receivers' uncertainty perceptions, we conducted a series of experimental pilot studies. We use single-factor, within-subject designs for (1) task information, (2) personal information, (3) concreteness, and (4) affective intensity. For each pilot study, between 50 and 53 U.S. consumers, with a mean age of 37.6 years (50\% women), were recruited from Amazon MTurk (for details, see Web Appendix G). In line with previous research (e.g., Hamilton and Hunter 1998; Larrimore et al. 2011; Ma et al. 2017; Packard and Berger 2020), we find that greater use of all four communication aspects in bids significantly reduces buyers' uncertainty perceptions and affects their hiring intentions.

\section{Predicting the Success of Buyers' Calls for Bids}

Model-free evidence. In Web Appendix H, we summarize the model-free findings. The mean-level comparison indicates that calls for bids with significantly greater degrees of task information and concreteness, as well as significantly lower degrees of personal information and affective intensity, receive more freelance bids than does an average call for bids $(\mathrm{M}=5)$.

Econometric model and identification. The success of calls for bids reflects a count variable. Noting the overdispersion in the data $(p<.001)$, we use a negative binomial model instead of a Poisson model. Furthermore, calls for bids are nested within buyers, and thus the call for bids and number of freelancers who offer their service might be interdependent. The significant between-group variance $(p<.001)$ and $\mathrm{ICC}_{(1)}$ of .27 suggests a multilevel structure. 
We thus specify a multilevel model with a random intercept to control for time-invariant unobserved differences between buyers (e.g., education, country, gender) that could relate to differences in their success, using the following base equation:

$$
\begin{aligned}
\left(1 \text { CALSUC }_{i j}\right. & \\
& =y_{00}+y_{01} B T A S K_{i j}+y_{02} B P E R S_{i j}+y_{03} B C O N C_{i j}+y_{04} B I N T E_{i j}+y_{05} B T A S I \\
& +y_{06} B P E R S_{-} S Q_{i j}+y_{07} B C O N C \_S Q_{i j}+y_{08} B I N T E_{-} S Q_{i j}+\mu_{0 j}+\varepsilon_{i j},
\end{aligned}
$$

where $C A L S U C_{i j}$ is the success of a call for bids $\mathrm{i}(\mathrm{i}=1, \ldots, 343,796)$ issued by buyer $\mathrm{j}(\mathrm{j}=1, \ldots$, 49,081), BT ASK $K_{i j}$ is buyer task information, $B P E R S_{i j}$ indicates buyer personal information, $B C O N C_{i j}$ is buyer concreteness, and $B I N T E_{i j}$ refers to buyer affective intensity in the call for bids. In turn, $B T A S K_{-} S Q_{i j}$ is buyer task information squared, $B P E R S_{-} S Q_{i j}$ is buyer personal information squared, $B C O N C_{-} S Q_{i j}$ is buyer concreteness squared, and $B I N T E_{-} S Q_{i j}$ is buyer affective intensity squared. Finally, $\mu_{0 j}$ is the random intercept, and $\varepsilon_{i j}$ is the error term.

Some empirical challenges inhibit a robust model identification, which we address in several ways. To account for observed heterogeneity, we incorporate covariates that might influence how many freelancers respond to a particular call for bids. First, in line with extant text mining studies (Berger et al. 2020), we control for the word count in each call for bids. Second, as a reputation cue, we measure buyer experience as the number of projects a buyer has commissioned previously on the platform, prior to posting the focal call for bids (Hong and Pavlou 2017). Third, a higher payment offer may attract more freelancers (Horton 2019), so we determine the payment offered by the buyer in U.S. dollars, multiplied by an undisclosed index for anonymity. For non-disclosed payments, we use a dummy, but we replace missing values with a grand mean to retain the observations. Fourth, we measure project duration; longer projects attract more freelancers (Horton 2019). A dummy variable indicates if the project is slated to last more (1) or less than a month (0). Fifth, more buyers demanding freelance services 
at the same time creates a relative shortage of freelancers (Horton 2019). To account for an excess supply of freelancers, we take the sum of all active freelancers in the specific submarket of the call for bids, divided by the sum of all calls for bids posted around the same time $( \pm 31$ days) in the same submarket. Sixth, the marketplace grew over time, so we included fixed effects for the year of the call for bids. Seventh, we include fixed effects for the seven submarkets, since submarkets that feature more complex projects have fewer qualified freelancers.

Beyond these observed covariates, buyers' bid formulations might vary by project characteristics unobservable to us. To the extent that these unobserved project characteristics influence both the buyers' communication strategies and buyer outcomes, the estimated parameters might be biased. Therefore, we concatenated all service skill tags from the service profile of each freelancer who submitted a bid in response to a specific call. Then, to uncover the latent mixture of project types, we applied a latent dirichlet allocation model to the projectspecific skill tags (e.g., Berger et al. 2020; see Web Appendix I). We include the resulting 12 latent project characteristics as fixed effects to account for unobserved heterogeneity.

Buyers also make their communication decisions strategically, in learned anticipation of a larger number of bids or other factors, potentially unobservable to us. This strategic behavior could make communication approaches endogenous (Kanuri, Chen, and Sridhar 2018). Because our data do not contain valid, strong instruments for buyers' communication, we adopt Park and Gupta's (2012) approach and use Gaussian copulas to model the correlation between each buyer communication $B C O M_{i j}^{1-4}$ and the error term. We add regressors to Equation 1, such that

$$
\widetilde{B C O M_{i j}^{1}}-4=\Phi^{-1}\left[H\left(B C O M_{i j}^{1-4}\right)\right]
$$

where $\Phi^{-1}$ is the inverse of the normal cumulative distribution function, and $\left[H\left(B C O M_{i j}^{1-4}\right)\right]$ represents the empirical distribution functions of the four buyer communication approaches. The 
endogenous regressors must be non-normally distributed for identification (Park and Gupta 2012), which Shapiro-Wilks tests confirm (all $p<.001$ ). The updated equation to predict buyers' call for bids success, after correcting for endogeneity, thus is:

$$
\begin{aligned}
& \text { (3 } \text { CALSUC }_{i j} \\
& \text { ) } \quad=y_{00}+y_{01} B_{T A S K_{i j}}+y_{02} B P_{E R S_{i j}}+y_{03} B_{C O N C_{i j}}+y_{04} B_{I N T E}+y_{05} B T A S I \\
& +y_{06} B P E R S_{-} S Q_{i j}+y_{07} B C O N C_{-} S Q_{i j}+y_{08} B I N T E_{-} S Q_{i j}+y_{09-14} C O N_{i j}^{1-6} \\
& +y_{15-20} Y_{E A R_{i j}^{1}-6}+y_{21-26} S U B M_{i j}^{1-6}+y_{27-37} \text { PROJ }_{i j}^{1-11}+y_{38-41} B \widetilde{C O M} \\
& { }_{i j}^{1-4}+\mu_{0 j}+\varepsilon_{i j} \text {, }
\end{aligned}
$$

where $C O N_{i j}^{1-5}$ is the vector of control variables, $Y E A R_{i j}^{1-6}$ are year effects, $S U B M_{i j}^{1-6}$ are submarket effects, $P R O J_{i j}^{1-11}$ are latent project clusters, and $B \widetilde{C O} M_{i j}^{1-4}$ are Gaussian copulas.

We used a robust estimator to account for correlated and clustered standard errors.

Results and discussion. The maximum variance inflation factor is 2.11 , indicating no potential threat of multicollinearity. Table 2 contains the results of a main-effects model and the full model, and Figure 2 displays the curvilinear effects from the full model. We have proposed that extremely sparse and extremely dense degrees of relevant information, concreteness, and affective intensity in calls for bids yield fewer freelance bids than moderate degrees of these communication elements. In line with our expectations, we find a positive linear effect $(.152, p<$ $.01)$ and negative squared effect for task information $(-.026, p<.01)$, as displayed in Figure 2, Panel A. Moderate levels of the use of task information $(50 \%: .222, p<.01)$ yield better results than sparse $(10 \%:-.426, p<.01)$ and dense $(90 \%:-.495, p<.01)$ uses. Furthermore, we find a positive linear effect $(.052, p<.01)$ and negative squared effect for concreteness $(-.080, p<.01)$ (Figure 2, Panel C). Moderate use (50\%: .078, $p<.01)$ yields better results than sparse use $(10 \%$ : $-.092, p<.01)$ or dense use $(90 \%:-.251, p<.01)$ of concreteness. Contrary to our expectation, we find a negative linear effect $(-.190, p<.01)$ and a positive squared effect $(.032, p<.01)$ of personal information (Figure 2, Panel B). We also find a negative linear effect $(-.084, p<.01)$ 
and a non-significant squared effect $(.001, n s)$ of affective intensity (Figure 2, Panel D). Thus, it appears that any provision of personal information or greater use of affective intensity by the buyer is always ineffective. As a possible explanation, we note that in B2B online conversations, self-disclosure and emotions may be valued only after business relations have been established, not at the moment they form (Koponen and Rytsy 2020). Most of the exchanges in our data are between strangers, rather than repeat exchanges, so buyers may more appropriately avoid personal details and appear rational rather than emotive.

To entice more freelancers to bid, buyers should keep their calls for bids brief $(-.027, p<$ .01 for word count), which emphasizes the need for careful formulations. Higher payment offers $(.168, p<.01)$, longer project durations $(.117, p<.01)$, and an excess supply of freelancers $(.606$, $p<.01)$ all increase the number of bids. Notably, the number of projects a buyer previously has commissioned relates negatively to the number of freelance who bid $(-.033, p<.01)$. These experienced buyers might have established relations with specific freelancers, which reduces other freelancers' chances, so they refrain from bidding (Lanzolla and Frankort 2016).

[please insert Table 2 and Figure 2 here]

\section{Predicting Freelancers' Bid Success}

Model-free evidence. Bids that offer greater task information, concreteness, and affective intensity and less personal information are more successful in winning projects. Among bids that won, the mean-level comparisons indicate nonlinear effects of mimicry. That is, successful freelancers mimic buyers' use of task information, personal information, and concreteness closely. If a buyer uses very sparse or very dense degrees of these communication aspects, the winning freelancers deviate more, indicating a nonlinear impact of mimicry. We do not find evidence of this mimicry relationship for affective intensity (see Web Appendix H). 
Measurement of similarity. Previous studies often operationalize communication similarity as the absolute difference between two measures (e.g., Ludwig et al. 2013; Soliz and Giles 2014), but this approach suffers some implicit constraints (Edwards and Parry 1993). In particular, difference scores suggest that one party's communication increases at the same magnitude as the other's decreases; they also ignore the level of communication at which relative mimicry occurs. As a preferable alternative, we use polynomial regression, which allows for simultaneous testing of similarity and dissimilarity effects on bid success, at different levels of freelancers' and buyers' uses of the four communication aspects. In their study of positive and negative emotional tone convergence, Gooty et al. (2019) also use polynomial regression to explore the nuanced effects of convergence in leader-follower relationships on leader-member exchange quality. A simple regression model, capturing absolute deviation, cannot simultaneously assess the degree of task information by the buyer and the potential nonlinear effects of task information mimicry by the freelancer. So, we undertake polynomial regression with response surface analyses for each communication aspect to capture the extent to which freelancers mimic a prospective buyer's provision of relevant information and communication manner. We detail this polynomial modeling approach that lead to Equation 4 and the calculation of all polynomial terms, using task information as an example, in Web Appendix E.

Econometric model and identification. We test freelancers' trade-off between adding more uncertainty-reducing communication versus mimicking the buyer's communication in a polynomial regression model that includes linear terms, quadratic terms, and interactions. In the multilevel base equation to predict freelancers' bid success $\left(\operatorname{ICC}_{(1)}=.09, p<.001\right)$, (4) BIDSUC $k$ l ) $\quad=y_{00}+y_{01-04} F_{C O M}^{1-4}+y_{05-}{ }_{08} B_{C O M}{ }_{k l}^{1-4}+y_{09-12} F_{C O M} S Q_{k l}^{1-4}+y_{1:}$ FCOM $_{k l}^{1-4} \times$ BCOM $\left._{k l}^{1}{ }^{4}\right)+y_{17-20} B C O M_{-} S Q_{k l}^{1-4}+\mu_{0 l}+\varepsilon_{k l}$, 
BIDSUC $_{k l}$ is the success of bid $\mathrm{k}(\mathrm{k}=1, \ldots, 2,327,216)$ by freelancer $\mathrm{l}(\mathrm{l}=1, \ldots, 34,851)$, $\mathrm{FCOM}_{k l}^{1-4}$ are the four freelancer communication aspects, $B C O \mathrm{M}_{k l}^{1-4}$ indicate the four buyer communication aspects, $F C O M_{-} S Q_{k l}^{1-4}$ are freelancer communication squared, $\left(F C O M_{k l}^{1-4} \times\right.$ $B C O M_{k l}^{1}{ }^{4}$ ) are interactions of freelancer and buyer communication aspects, $B C O M_{-} S Q_{k l}^{1}-4$ are buyer communication squared, $\mu_{0 l}$ is the random intercept, and $\varepsilon_{k l}$ is the error term.

We incorporate several covariates that might influence freelancers' bid success. As in the buyer model, we control for word count, project payment, project duration, and excess supply of active freelancers. We also include fixed effects for years, submarkets, and latent project characteristics. We account for the number of projects the freelancer completed prior to submitting the focal bid as a reputation cue that might determine bid success (Hong and Pavlou 2017). Freelancer rating is an average five-point satisfaction rating that a freelancer has received for all completed projects. To retain observations of unrated freelancers, we include a dummy for observations without star ratings and replace the missing values with a grand mean rating.

Several additional controls relate to whether a bid is successful. First, following prior research, we assess linguistic style matching (LSM), or the similarity between each bid and the respective call for bids, across nine function word categories (Ludwig et al. 2013). Second, we account for any previous relationship, such that the freelancer completed at least one project for the same buyer prior to the specific call for bids (Hong and Pavlou 2017). Third, freelancers submit a bid price that may differ from the payment offered by the buyer; a higher bid price may reduce the likelihood of bid success (Hong and Pavlou 2017). We measure each bid price as a ratio, between the asking price and the average indexed bid price requested by all competing freelancers for the same call for bids. Fourth, the longer it takes freelancers to submit a bid, the lower their chances of success (Hong, Wang, and Pavlou 2016). We measure time-to-bid as the 
number of days between the posting of the call for bids and the bid submission. A dummy variable also indicates if the bid was submitted late (1) or on time (0); though some buyers might accept bids submitted after the auction expiration date, late bids are less likely to succeed (Horton 2019). Fifth, competition for a specific call for bid should impact each bid's success chances, so we control for the number of bids for the same call (Hong, Wang, and Pavlou 2016).

Similar to buyers, freelancers make communication decisions strategically in anticipation of higher bid success or other, unobservable factors. Thus, freelancer communication is potentially endogenous, and we again use Gaussian copulas (Shapiro-Wilks tests: all $p<.001$ ). The updated equation to predict freelancers' bid success is as follows:

$$
\begin{aligned}
& \text { (5 } B I D S U C_{k l} \\
& \text { ) } \quad=y_{00}+y_{01-04}{ }_{F C O M}^{1-4}+y_{05-08} B C O M_{k l}^{1-4}+y_{09-12} F_{C O M} S Q_{k l}^{1-4}+y_{1} \text { : }
\end{aligned}
$$

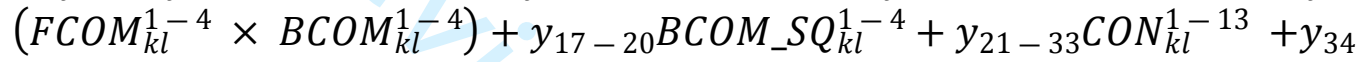

$$
\begin{aligned}
& Y E A R_{k l}^{1-6}+y_{40-45} S U B M_{k l}^{1-6}+y_{46-56}{ }^{P R O J} J_{k l}^{1-11}+y_{57-60} F \widetilde{C O M} M_{k l}^{1-4} \\
& +y_{61-64} B \widehat{C O} M_{k l}^{1-4}+\mu_{0 l}+\varepsilon_{k l} \text {, }
\end{aligned}
$$

where $C O N_{k l}^{1-14}$ is the vector of control variables, $Y E A R_{k l}^{1-6}$ are year effects, $S U B M_{k l}^{1-6}$ are submarket effects, $P R O J_{k l}^{1-11}$ are latent project clusters, $F \widetilde{C O} M_{k l}^{1-4}$ are Gaussian copulas for bid text, and $\overparen{B C O} M_{k l}^{1-4}$ are Gaussian copulas for calls for bids text.

Results and discussion. The maximum variance inflation factor is 3.86 , indicating no threat of multicollinearity. Table 3 contains the results of the freelancer bid success models, Web Appendix K summarizes the response surface coefficients, and Figure 3 displays these coefficients on three-dimensional surfaces, reflecting relationships among freelancer communication, buyer communication, and bid success. We also highlight the misfit line used to explore the trade-off between exceeding and falling short of buyers' communication levels.

We have proposed that when the degree of relevant information, concreteness, and affective intensity provided by the buyer is at least moderately dense (sparse), freelancers can 
increase (decrease) their chances of bid success by mimicking the buyer's communication. The surface-level tests along the plotted misfit line (Web Appendix K) display negative curvatures for task information $(-.020, p<.01)$, personal information $(-.007, p<.01)$, concreteness $(-.011, p$ $<.01)$, and affective intensity $(-.020, p<.01)$. These results indicate that mimicking the buyer's communication increases bid success (see Web Appendix L for further clarification).

In line with our proposition, we qualify this effect for sparse degrees of task and personal information, concreteness, and affective intensity provided by the buyer in Web Appendix M. If we were to find positive slope coefficients at lower levels, it would suggest that freelancers can increase their chances of bid success by exceeding, rather than mimicking the buyer's communication. This prediction holds for personal information $(.020, p<.01)$ and concreteness $(.024, p<.01)$, according to the slopes at low levels of buyer communication. But contrary to our expectations, we find negative effects for the slopes of task information $(-.008, p<.01)$ and affective intensity $(-.030, p<.01)$ at low levels of buyer communication. Therefore, freelancers should always mimic the degree of task information and affective intensity provided by the buyer. For these two communication aspects, the tenets of communication accommodation theory (Soliz and Giles 2014) and adaptive selling (Verbecke et al. 2011) hold: Mimicking the buyer is always better. To increase their chances of bid success further, freelancers also must keep their bids concise $(-.021, p<.01$ for word count). Reputation cues (experience: .002, $p<$ .01 ; rating: .010, $p .01$ ) increase freelancers' chances of bid success, as do linguistic style matching $(.051, p<.01)$, previous business relations with the buyer $(.078, p<.01)$, lower bid prices (-.006, $p<.01)$, timely (cf. late) bid submissions (-.004, $p<.01)$, lack of competition ($.251, p<.01)$, and reduced supply of freelancers $(-.042, p<.01)$.

[please insert Table 3 and Figure 3 here] 


\section{Predicting Freelancers' Price Premium}

Model-free evidence. Bids with significantly more task information, personal information, and concreteness and significantly less affective intensity achieve greater price premiums than an average bid ( $\mathrm{M}=14 \%$ discount $)$. Moreover, $96 \%$ of freelancers completed projects without any price premium, indicating the prevalence of value traps. The bids that achieved price premiums mimicked those buyers that made moderate use of task information, concreteness, and affective intensity closely, yet they deviated from buyers that made very sparse or very dense use of them. For personal information, we find a distinctive, positive, linear relationship for mimicry; successful freelancers mimicked buyers that supplied a lot of personal details but deviated if buyers supplied very little or moderate degrees of personal information (Web Appendix H).

Econometric model and identification. The price premium analysis is restricted to bids that win and buyers that disclose their payment offer upfront. Thus, our estimates may be biased by self-selection by buyers, in terms of which bid they choose and whether they disclose payments. Therefore, we employ a two-stage selection model. In the first stage, we estimate a choice model, with the availability of the necessary data as a binary dependent variable (i.e., bid was won, and payment was disclosed). From this model, we compute the inverse Mills ratio to account for the potential selection bias (probit model in Web Appendix N) and include this correction term in the final model estimation. To identify second-stage parameters, there needs to be one term in first-stage equation that is unrelated to the error term in the freelance price premium equation. We thus included the dummy that indicates if the bid was submitted late only in the first-stage equation because this term explains buyers' choice of the bid but we do not expect it to be conceptually related with the eventual price premium. Thus, we believe that this term satisfies both relevance and exogeneity requirements. The updated equation of our 
multilevel model $\left(\mathrm{ICC}_{(1)}=.13, p<.001\right)$ is as follows:

$$
\begin{aligned}
& \text { (6 PREMIUM } M_{k l}=y_{00}+y_{01-04} \text { FCOM }_{k l}^{1-4}+y_{05-08} \text { BCOM }{ }_{k l}^{1-4}+y_{09-12} \text { FCOM_SQ }_{k l}^{1-4} \\
& \text { ) } \quad+y_{13-16}\left(\text { FCOM }_{k l}^{1-4} \times \text { BCOM }_{k l}^{1-4}\right)+y_{17-20} \text { BCOM_SQ }_{k l}^{1-4}+y_{21-31} \text { CON }_{k}^{1} \\
& +y_{32-37} Y E A R_{k l}^{1-6}+y_{39-43} S U B M_{k l}^{1-6}+y_{44-54} P_{R O J}^{1-11}+y_{55-58}{ }^{1-} \widetilde{C O M} \\
& { }_{k l}^{1-4}+y_{59-62} B \widetilde{C O} M_{k l}^{1-4}+y_{63} I M R_{k l}+\mu_{0 l}+\varepsilon_{k l} \text {, }
\end{aligned}
$$

where $P R E M I U M_{k l}$ is the price premium of bid $\mathrm{k}(\mathrm{k}=1, \ldots, 148,158)$ offered by freelancer $\mathrm{l}(\mathrm{l}=$ $1, \ldots, 30,851)$, and $I M R_{k l}$ is the correction term.

Results and discussion. The maximum variance inflation factor is 2.74 , indicating no threat of multicollinearity. Table 4 contains the results of the freelancer price premium models, Web Appendix K details the response surface coefficients, and Figure 3 displays the surfaces.

We have proposed that when the degree of relevant information and communication manner provided by the buyer is at least moderately high (low), freelancers can increase (decrease) their chances of earning a price premium by mimicking this communication. Web Appendix $\mathrm{O}$ displays the misfit lines on two-dimensional planes. In line with our expectations, the surface-level tests along the plotted misfit line show a negative curvature for task information $(-.023, p<.01)$, concreteness $(-.007, p<.01)$, and affective intensity $(-.008, p<.01)$, such that mimicking the buyer's communication increases bid success. Yet for personal information, we find a positive curvature $(.003, p<.05)$, which implies freelancers should always offer more personal information than the buyer. For these B2B services, the provider and the service are inseparable, which may lead buyers to place more value on personal information about freelancers, even if their own provision of personal details in the calls for bids is sparse.

At low levels of relevant information and communication manner established by the buyer (Web Appendix P), a positive slope would suggest that freelancers can increase their chances of earning a price premium by exceeding rather than mimicking the buyer. We find support for this 
prediction in the slope of personal information $(.027, p<.01)$ at low levels of buyer personal information. However, negative effects emerge from the slopes of task information $(-.016, p<$ $.01)$ and affective intensity $(-.012, p<.01)$, and we find a non-significant effect for concreteness $(.002, n s)$. Mimicking the buyer's task information and affective intensity is always better, in line with accommodation theory and adaptive selling (Soliz and Giles 2014; Verbecke et al. 2011).

Freelancers also increase their price premiums by avoiding lengthy bids $(-.014, p<.01)$. Although platform reputation cues (experience and rating) can boost freelancers' chances of bid success, they do not determine the final price buyers pay. The skew in the ratings, toward very high scores, may limit their ability to help prospective buyers determine an appropriate price (Kokkodis and Iperirotis 2016). Linguistic style matching $(.023, p<.01)$, a previous relationship with the prospective buyer $(.056, p<.01)$, submitting early in the bid process $(.009, p<.01)$, and reduced competition $(-.015, p<.01)$ all increase buyers' acceptance of a price premium.

[please insert Table 4 here]

\section{General Discussion}

Across disciplines, substantial research has tried to identify success determinants in online freelance marketplaces (e.g., Horton 2019; Srivastava and Chandra 2018). For example, studies of B2B exchanges and two-sided marketplaces emphasize communication (see Web Appendix
A). But at the specific word level, we lack insights into the optimal information or manner of
communication (Berger et al. 2020). With this initial investigation of how buyers' and
freelancers' success might be enhanced by appropriately managing the other party's uncertainty, we postulate, in line with uncertainty reduction (Berger and Calabrese 1975) and uncertainty management (Brashers 2001) theories, that communication that is not completely informative and clear still may be effective. Accordingly, we investigate how buyers' communication can 
attract freelance bids and freelancers' communication can determine their bid success and price most effectively, and the results offer both theoretical and practical implications.

\section{Theoretical Contributions}

First, we advance research on how buyers' communication determines their ability to attract freelancers. Drawing on prior communication research, we identify communication principles that critically relate to receivers' uncertainty, such as relevant task and personal information and the relative concreteness and affective intensity with which this information is communicated (Giles 1975; Bradac 2001). To entice more freelancers to bid, buyers should carefully formulate their calls for bids to keep them brief. Freelancers' information processing motivation, time, skills, and proficiency likely are limited, so buyers must choose their wording carefully and select among different effective communicative aspects. They can attract a larger pool of bids if they provide moderate degrees of task information in a moderately concrete manner. Offering too little of these features leaves freelancers with too much uncertainty; dense information provision or being very concrete is too restrictive. If buyers provide greater degrees of personal information or express greater affective intensity in their calls for bids, it reduces the number of service offers they receive. This finding contrasts with uncertainty reduction theory (Berger and Calabrese 1975) and B2B research that suggests self-disclosure strengthens buyerseller cooperativeness (Joshi 2009). However, instead of ongoing B2B relationships, our study refers mostly to initial interactions between strangers (in $98 \%$ of cases, the freelancer had never worked for the prospective buyer). Evidence obtained from buyer-seller online chats similarly suggests that self-disclosure and emotive expressions are valued only in existing B2B relationships, not in new ones (Koponen and Rytsy 2020). Overall, we offer empirical support for communication theorists' suggestions that common communication principles can be 
purposefully flouted to achieve better conversation outcomes (Goffman 2008).

Second, freelancers must keep their bids concise. They too face a trade-off between reducing the buyer's uncertainty and offering overly dense information. In line with research on communication accommodation (Soliz and Giles 2014) and adaptive selling (Verbeke, Dietz and Verwaal 2011), we show that freelancers can improve their bid success by mimicking the prospective buyer's communication. Adding to these research streams, we introduce a contingency perspective that reveals that the efficacy of mimicry depends on the degree to which buyers use specific communication elements. In line with accommodation theory and adaptive selling, bid success always improves when freelancers mimic buyers' provision of task information and use of affective intensity. But in line with uncertainty reduction theory (Berger and Calabrese 1975) and expectancy violations (Afifi and Burgoon 2000), when buyers supply little personal information and are less concrete, freelancers can increase their chances of bid success by diverging and providing more personal information and concreteness.

Third, freelancers often struggle to avoid value traps, in which they sell more of their services for less (Sridhar and Mittal 2020). Rational buyer expectations should allow highquality freelancers to charge price premiums (Rao and Monroe 1996), but the quality of freelance services is unobservable prior to purchase, and rational buyers might refuse to pay any price premium if they are uncertain and suspect hidden information (Dimoka et al. 2012). Therefore, to achieve premiums, freelancers should offer short, appropriately formulated bids. Buyers are more willing to pay a premium to freelancers who mimic their provision of task information, concreteness, and affective intensity, in line with communication accommodation theory (Soliz and Giles 2014) and adaptive selling research (Verbeke, Dietz, and Verwaal 2011). However, similar to the findings for bid success, freelancers should offer more, rather than 
mimic, buyers' provision of personal information. In most service settings, a "bad" seller might provide a great product by chance; almost by definition though, a bad freelancer produces bad service (Horton 2019). This tight coupling between the freelancer and service quality represents a conceptual distinction of our study, which accordingly shows that buyers' willingness to pay a premium increases with more personal information issued by the freelancer.

\section{Practical Implications}

The findings offer actionable insights for the millions of buyers and freelancers working in online freelance marketplaces, the value of which are predicted to reach $\$ 2.7$ trillion by 2025 (Manyika et al. 2015). In detail, being informative and unambiguous may be a common assumption, but it is not an imperative, nor does it always lead to success.

Implications for buyers. Although 59\% of U.S. companies use a flexible workforce to some degree, more than one-third of contracted projects are never completed (Hong and Shao 2021). To attract freelancers, buyers should keep their calls for bids succinct. Beyond that recommendation, we offer several tips for formulating calls for bids in Table 5. In detail, a task description with a moderate amount of information helps freelancers anticipate the task, without overloading them with details. Due to the relative anonymity of online freelance marketplaces, buyers might assume that freelancers will need to know who they are, but instead, we find that the less buyers describe themselves (to focus on describing the task), the better the outcomes. Relatable and imaginable, rather than abstract, descriptions of the project help freelancers grasp the requirements. However, being excessively concrete becomes prescriptive, which deters freelancers. Using emotion words makes the content of a call for bids relatively more intense. Such intensity can remove ambiguity and make opinions quickly accessible, but we find that calls for bids are more effective if they are formulated relatively impassively; enthusiastic project 
descriptions seemingly might raise freelancers' suspicion that the project is too good to be true. Offering a higher payment might attract a larger pool of freelance bids, as do long- rather than short-term gigs. Finally, more freelancers bid when there are less calls for bids in the subsector.

Implications for freelancers. Freelancers are not necessarily natural marketers, but their bid formulations determine their marketability. Existing online reputation systems provide some assistance, but they also create entry barriers to new freelancers who first must earn good overall ratings (Constantinides, Henfridsson, and Parker 2018). Fortunately, winning gigs and achieving price premiums also depends on freelancers' communication. Table 5 includes advice to help freelancers formulate more successful bids and avoid the value trap. In line with the mantra of adaptive selling, the call for bids provides a starting point, such that mimicking the buyer's task information and affective intensity increases freelancers' success - even if they provide few task details or seem very impassive. But freelancers should always offer personal information and be concrete. Even if a buyer does not provide personal information or the call is relatively abstract, freelancers' chances of success and price premiums increase if their bids contain more personal information and are at least somewhat concrete. The strongest predictor of bid success is a preexisting buyer relationship, so more broadly, freelancers should grow their buyer relations.

[please insert Table 5 here]

\section{Limitations and Directions for Further Research}

In examining theoretically grounded communicative aspects, we offer novel insights into how to manage uncertainty in buyer-freelancer exchanges. Intriguingly, we find that communication approaches that do not aim to minimize uncertainty can be effective. Continued research should investigate this notion further and develop additional insights into the exchange implications of linguistic choices in B2B but also business-to-consumer and consumer-to- 
consumer communication on multi-sided platforms (Luo et al. 2021). For example, affiliative (Pennebaker et al. 2015) or collaborative terms might affect uncertainty and influence exchanges too. Arguably, the personal characteristics of buyers and freelancers (e.g., gender, education, experience), channel choices (Lawrence et al. 2019), different sources of uncertainty (Heide and Weiss 1995), perceived risks (Grewal, Gotlieb, and Marmorstein 1994), and spatial distances between buyers and freelancers also might moderate the efficacy of communication aspects, so additional research should specify their influences. For example, if buyers lack the expertise to specify what they want, they might benefit from more ambiguous calls for bids (Humphreys et al. 2020). Perhaps buyers' communication or alternative factors which we cannot account for (e.g. underestimation of the amount of work required to fulfil the task), influence the final price they pay too. Efforts to specify these additional effects also might address some of our more controversial findings, such as the evidence that the number of previously commissioned projects by a buyer relates negatively to the number of freelancers who bid. We posit that experienced buyers might prefer freelancers whom they have hired in the past (Lanzolla and Frankort 2016), but they also might have incurred switching costs or dependencies (Heide and Weiss 1995). Methodologically, we estimated all the models sequentially; buyers' calls for bids and their success occur prior to freelancers' bids and their success. But an equilibrium approach that estimates these models simultaneously at the bid level could reflect an alternative way to think about the data structure. The concreteness word list we use (Brysbaert et al. 2014) may require further refinement too, to differentiate specific concreteness levels among the set of concrete words. Finally, the anonymity and speed of exchanges in online freelance marketplaces may make communication particularly important; a comparative analysis of the influence of uncertainty management efforts across different B2B contexts, beyond these marketplaces, could 
offer interesting insights, especially if uncertainty avoidance is a central goal.

1
2
3
4
5
6
7
8
9

3
4
5
6
7
8
9
10

10

12

13

14

15

16

17

18

19

20

21

22

24

25

26

27

28

29

30

31

32

33

34

35

36

37

38

39

40

41

42

43

44

45

46

47

48

49

50

51

52

53

54

55

56

57

58

59

60

Journal of Marketing 


\section{References}

Afifi, Walid A. and Judee K. Burgoon (2000), "The Impact of Violations on Uncertainty and the Consequences for Attractiveness," Human Communication Research, 26 (2), 203-233.

Albers, Sönke, Murali K. Mantrala, and Shrihari Sridhar (2010), "Personal Selling Elasticities: A Meta-Analysis," Journal of Marketing Research, 47 (5), 840-853.

Ba, Sulin and Paul A. Pavlou (2002), "Evidence of the Effect of Trust Building Technology in Electronic Markets: Price Premiums and Buyer Behavior," MIS Quarterly, 26 (3) 243-268.

Bayer, Emanuel, Kapil R. Tuli, and Bernd Skiera (2017), "Do Disclosures of Customer Metrics Lower Investors' and Analysts' Uncertainty but Hurt Firm Performance?" Journal of Marketing Research, 54 (2), 239-259.

Benoit, Kenneth, Paul Nulty, Pablo Barber, Kohei Watanabe, and Benjamin Lauderdale (2018), Quantitative Analysis of Textual Data, https://cran.r-project.org/web/packages/quanteda/.

Berger, Charles R. (2011), "From Explanation to Application,” Journal of Applied Communication Research, 39 (2), 214-222.

Berger, Charles R., and Richard J. Calabrese (1975), "Some Explorations in Initial Interaction and Beyond: Toward a Developmental Theory of Interpersonal Communication," Human Communication Research, 1 (2), 99-112.

Berger, Jonah, Ashlee Humphreys, Stephan Ludwig, Wendy W. Moe, Oded Netzer, and David A. Schweidel (2020), "Uniting the Tribes: Using Text for Marketing Insight," Journal of Marketing, 84 (1), 1-25.

Bradac, James J. (2001), “Theory Comparison: Uncertainty Reduction, Problematic Integration, Uncertainty Management, and Other Curious Constructs," Journal of Communication, 51 (3), 456-476.

Brashers, Dale E. (2001), "Communication and Uncertainty Management," Journal of Communication, 51(3), 477-497.

Brown, Penelope and Stephen C. Levinson (1987), Politeness: Some Universals in Language Usage, Cambridge: Cambridge University Press.

Brysbaert, Marc, Amy Beth Warriner, and Victor Kuperman (2014), "Concreteness Ratings for 40 Thousand Generally Known English Word Lemmas," Behavior Research Methods, 46(3), 904- 911.

Collins, Nancy L. and Lynn C. Miller (1994), "Self-Disclosure and Liking: A Meta-Analytic Review," Psychological Bulletin, 116 (3), 457-475.

Constantinides, Panos, Ola Henfridsson, and Geoffrey G. Parker (2018), "IntroductionPlatforms and Infrastructures in the Digital Age," Information Systems Research, 29 (2), 381-400. 
Crosby, Lawrence A., Kenneth R. Evans, and Deborah Cowles (1990), "Relationship Quality in Services Selling: An Interpersonal Influence Perspective," Journal of Marketing, 54 (3), 68-81.

Derlega, Valerian J., Marian Sue Harris, and Alan L Chaikin (1973), "Self-Disclosure Reciprocity, Liking and the Deviant," Journal of Experimental Social Psychology, 9 (4), 277-284.

Dimoka, Angelika, Yili Hong, and Paul A. Pavlou (2012), "On Product Uncertainty in Online Markets: Theory and Evidence,” MIS Quarterly, 36 (2), 395-426.

Edwards, Jeffrey R. and Mark E. Parry (1993), "On the Use of Polynomial Regression Equations as an Alternative to Difference Scores in Organizational Research," Academy of Management Journal, 36 (6), 1577-1613.

Eisenberg, Eric M., and Marsha G. Witten (1987), "Reconsidering Openness in Organizational Communication," Academy of Management Review, 12 (3), 418-426.

Engelhardt, Paul E., Karl Bailey, and Fernanda Ferreira (2006), “Do Speakers and Listeners Observe the Gricean Maxim of Quantity?" Journal of Memory and Language, 54 (4), 554573.

Farris, Paul W., Neil Bendle, Phillip E. Pfeifer, and David Reibstein (2010), Marketing Metrics: The Definitive Guide to Measuring Marketing Performance. London: Pearson Education.

Ghosh, Mrinal and George John (2005), "Strategic Fit in Industrial Alliances: An Empirical Test of Governance Value Analysis," Journal of Marketing Research, 42 (3), 346-57.

Goffman, Erving (1959), The Presentation of Self in Everyday Life. New York: Doubleday.

Goffman, Erving (2008). Interaction Ritual: Essays on Face-to-Face Behavior. New York: Pantheon Books.

Gooty, Janaki, Jane S. Thomas, Francis J. Yammarino, Jayoung Kim, and Melissa Medaugh (2019), "Positive and Negative Emotional Tone Convergence: An Empirical Examination of Associations with Leader and Follower LMX," The Leadership Quarterly, 30 (4), 427 439.

Grewal, Dhruv, Jerry Gotlieb, and Howard Marmorstein (1994), "The Moderating Effects of Message Framing and Source Credibility on the Price-Perceived Risk Relationship," Journal of Consumer Research, 21 (1), 145-153.

Grewal, Dhruv, Kent B. Monroe, and Ramayya Krishnan (1998), “The Effects of PriceComparison Advertising on Buyers' Perceptions of Acquisition Value, Transaction Value, and Behavioral Intentions," Journal of Marketing, 62 (2), 46-59.

Grice, Herbert P. (1975), "Logic and Conversation," in Syntax and Semantics: Speech Acts, Vol. 3, Peter Cole and Jerry Morgan, eds. New York: Academic Press, 41-58. 
Hamilton, Mark A. and John E. Hunter (1998), "The Effect of Language Intensity on Receiver Evaluations of Message, Source, and Topic," in Persuasion: Advances through MetaAnalysis, Mike Allen and Raymond W. Priess, eds. Cresskill, NJ: Hampton Press, 99-138.

Heide, Jan B., and Allen M. Weiss (1995), "Vendor Consideration and Switching Behavior for Buyers in High-Technology," Journal of Marketing, 59 (3), 30-43.

Holtgraves, T. (1997), "Styles of Language Use: Individual and Cultural Variability in Conversational Indirectness," Journal of Personality and Social Psychology, 73 (3), 624637.

Homburg, Christian, Martin Klarmann, and Sabine Staritz (2012), "Customer Uncertainty Following Downsizing: The Effects of Extent of Downsizing and Open Communication," Journal of Marketing, 76(3), 112-129.

Hong, Yili, and Paul A. Pavlou (2017), "On Buyer Selection of Service Providers in Online Outsourcing Platforms for IT Services,” Information Systems Research, 28 (3), 547-562.

Hong, Yili, Chong Wang, and Paul A. Pavlou (2016), "Comparing Open and Sealed Bid Auctions: Evidence from Online Labor Markets," Information Systems Research, 27 (1), 49-69.

Hong, Yili and Benjamin B. M. Shao (2021), "On Factors that Moderate the Effect of BuyerSupplier Experience on E-Procurement Platforms," Production and Operations Management, 30 (4), 1034-1051.

Horton, John J. (2019), "Buyer Uncertainty About Seller Capacity: Causes, Consequences, and a Partial Solution,” Management Science, 65 (8), 3518-3540.

Horton, John J. (2017), "The Effects of Algorithmic Labor Market Recommendations: Evidence from a Field Experiment," Journal of Labor Economics, 35 (2), 345-385.

Hosman, Lawrence A. (2002), "Language and Persuasion," in The Persuasion Handbook: Developments in Theory and Practice, James P. Dillard and Michael Pfau, eds. Thousand Oaks, CA: Sage, 371-390.

Humphreys, Ashlee, Mathew S. Isaac, and Rebecca Jen-Hui Wang (2020), "Construal Matching in Online Search: Applying Text Analysis to Illuminate the Consumer Decision Journey," Journal of Marketing Research, [available at https://doi.org/10.1177/0022243720940693].

Jap, Sandy D. (2007), “The Impact of Online Reverse Auction Design on Buyer-Supplier Relationships," Journal of Marketing, 71 (1), 146-59.

Jones, Quentin, Gilad Ravid, and Sheizaf Rafaeli (2004), "Information Overload and the Message Dynamics of Online Interaction Spaces: A Theoretical Model and Empirical Exploration," Information Systems Research, 15 (2), 194-210.

Joshi, Ashwin W. (2009), “Continuous Supplier Performance Improvement: Effects of Collaborative Communication and Control," Journal of Marketing, 73 (1), 133-50. 
Kanuri, Vamsi K., Yixing Chen, and Shrihari Sridhar (2018), "Scheduling Content on Social Media: Theory, Evidence and Application,” Journal of Marketing, 82(6), 89-108.

Keleman, Mihaela (2000), "Too Much or too Little Ambiguity: The Language of Total Quality Management," Journal of Management Studies, 37, 483-489.

Kokkodis, Marios and Panagiotis G. Ipeirotis (2016), "Reputation Transferability in Online Labor Markets," Management Science, 62 (6), 1687-1706.

Koponen, Jonna Pauliina, and Saara Rytsy (2020), "Social Presence and E-commerce B2B Chat Functions," European Journal of Marketing, 54 (6), 1205-1224.

Khosarvizadeh, Parvaneh and Nikan Sadehvandi (2011), "Some Instances of Violations and Flouting of the Maxim of Quantity by the Main Character (Barry and Tim) in Dinner for Schmucks," IPEDR, 26, Singapore: IACSIT Press.

Krippendorff, Klaus (2013), Content Analysis. An Introduction to Its Methodology, 3rd ed. Thousand Oaks, CA: Sage.

Lanzolla, Gianvito, and Hans T. W. Frankort (2016), "The Online Shadow of Offline Signals: Which Sellers Get Contracted in Online B2B Marketplaces?" Academy of Management Journal, 59 (1), 207-31.

Larrimore, Laura., Li Jiang, Jeff Larrimore, David Markowitz, and Scott Gorski (2011), "Peer to Peer Lending: The Relationship Between Language Features, Trustworthiness, and Persuasion Success," Journal of Applied Communication Research, 39 (1), 19-37.

Lawrence, Justin M., Andrew T. Crecelius, Lisa K. Scheer, and Ashutosh Patil (2019), "Multichannel Strategies for Managing the Profitability of Business-to-Business Customers," Journal of Marketing Research, 56 (3), 479-97.

Liu, Yeyi, Andreas B. Eisingerich, Seigyoung Auh, Omar Merlo, and Hae Eun Helen Chun (2015), "Service Firm Performance Transparency: How, When, and Why Does it Pay Off?” Journal of Service Research, 18 (4), 451-467.

Ludwig, Stephan, Ko de Ruyter, Mike Friedman, Elisabeth C. Brüggen, Martin Wetzels, and Gerard Pfann (2013), "More Than Words: The Influence on Affective Content and Linguistic Style Matches in Online Reviews on Conversion Rates," Journal of Marketing, 77 (1), 87-103.

Luo, Xueming, Siliang Tong, Zhijie Lin, and Cheng Zhang (2021), “The Impact of Platform Protection Insurance on Buyers and Sellers in the Sharing Economy: A Natural Experiment", Journal of Marketing, 85(2), 50-69.

Ma, Xiao, Jeffery T. Hancock, Kenneth Lim Mingjie, and Mor Naaman (2017), "Self-Disclosure and Perceived Trustworthiness of Airbnb Host Profiles," Proceedings of Computer Supported Cooperative Work (ACM), 2397-2409.

Ma, Zhenfeng and Laurette Dubé (2011), "Process and Outcome Interdependency in Frontline Service Encounters," Journal of Marketing, 75 (3), 83-98. 
Manyika, James, Susan Lund, Kelsey Robinson, John Valentino, and Richard Dobbs (2015), A Labor Market that Works: Connecting Talent with Opportunity in the Digital Age. San Francisco, CA: McKinsey Global Institute.

McFarland, Richard G., Goutam N. Challagalla, and Tasadduq A. Shervani (2006), "Influence Tactics for Effective Adaptive Selling,” Journal of Marketing, 70 (4), 103-17.

Mooi, Erik A., and Mrinal Ghosh (2010), "Contract Specificity and its Performance Implications," Journal of Marketing, 74 (2), 105-120.

Moon, Youngme (2000), "Intimate Exchanges: Using Computers to Elicit Self-Disclosure from Consumers," Journal of Consumer Research, 26 (3), 323-339.

Mullins, Ryan, Raj Agnihotri, and Zachary Hall (2020), “The Ambidextrous Sales Force: Aligning Salesperson Polychronicity and Selling Contexts for Sales-Service Behaviors and Customer Value," Journal of Service Research, 23 (1), 33-52.

Packard, Grant and Jonah Berger (2020), "How Concrete Language Shapes Customer Satisfaction," Journal of Consumer Research, 47 (5), 787-806.

Packard, Grant, Sarah G. Moore, and Brent McFerran (2018), "(I'm) Happy to Help (You): The Impact of Personal Pronoun Use in Customer-Firm Interactions," Journal of Marketing Research, 55 (4), 541-555.

Palmatier, Robert W., Rajiv P. Dant, and Dhruv Grewal (2007), “A Comparative Longitudinal Analysis of Theoretical Perspectives of Interorganizational Relationship Performance," Journal of Marketing, 71 (4), 172-94.

Pan, Lingling, Gerry McNamara, Jennifer J. Lee, Jerayr Haleblian, and Cynthia E. Devers (2018), "Give it to us Straight (Most of the Time): Top Managers' Use of Concrete Language and its Effect on Investor Reactions," Strategic Management Journal, 39 (8), 2204-2225.

Park, Sungho and Sachin Gupta (2012), "Handling Endogenous Regressors by Joint Estimation Using Copulas,” Marketing Science, 31 (4), 567-586.

Pennebaker, James W., Ryan L. Boyd, Kayla Jordan, and Kate Blackburn (2015), “The Development and Psychometric Properties of LIWC2015," retrieved from https://repositories.lib.utexas.edu/bitstream/handle/2152/31333/LIWC2015 LanguageManual.pdf

Pennebaker, James W., and Lori D. Stone. (2003), "Words of Wisdom: Language Use Over the Life Span,” Journal of Personality and Social Psychology, 85 (2), 291-301.

Pollock, Patrick, Dirk Lüttgens, and Frank T. Piller (2019), “Attracting Solutions in Crowdsourcing Contests: The Role of Knowledge Distance, Identity Disclosure, and Seeker Status," Research Policy, 48 (1), 98-114.

Putman, Linda and Tricia Jones (1982), "The Role of Communications in Bargaining," Human Communications Research, 8, 262-280. 
Rao, Akshay R., and Kent B. Monroe (1996), "Causes and Consequences of Price Premiums," Journal of Business, 69 (4), 511-535.

Shannon, Claude E. and Warren Weaver (1949), A Mathematical Model of Communication. Urbana: University of Illinois Press.

Singh, Jagdip and Deepak Sirdeshmukh (2000), "Agency and Trust Mechanisms in Consumer Satisfaction and Loyalty Judgments," Journal of the Academy of Marketing Science, 28 (1), 150-67.

Singh, Sunil K., Detelina Marinova, and Jagdip Singh (2020), "Business-to-Business ENegotiations and Influence Tactics,” Journal of Marketing, 84 (2) 47-68.

Snijders, Tom A. and Roel J. Bosker (2011), Multilevel Analysis: An Introduction to Basic and Advanced Multilevel Modeling. London: Sage.

Soliz, Jordan, and Howard Giles (2014), "Relational and Identity Processes in Communication: A Contextual and Meta-Analytical Review of Communication Accommodation Theory," Annals of the International Communication Association, 38 (1), 107-144.

Sridhar Hari and Vikas Mittal (2020), "Busting the Value Trap: How B2B Companies Can Increase Sales," BrandExtract. Available at:

https://www.brandextract.com/Insights/Articles/Busting-the-Value-Trap-How-B2BCompanies-Can-Increase-Sales/

Srivastava, Shirish C., and Shalini Chandra (2018), "Social Presence in Virtual World Collaboration: An Uncertainty Reduction Perspective Using a Mixed Methods Approach," MIS Quarterly, 42 (3), 779-803.

Stone, Philip J., and Earl B. Hunt (1963), “A Computer Approach to Content Analysis: Studies Using the General Inquirer System," in Proceedings of the May 21-23, 1963, Spring Joint Computer Conference, 241-256.

Verbeke, Willem, Bart Dietz, and Ernst Verwaal (2011), "Drivers of Sales Performance: A Contemporary Meta-Analysis. Have Salespeople Become Knowledge Brokers?" Journal of the Academy of Marketing Science, 39 (3), 407-428.

Weiss, Allen M., Nicholas H. Lurie, and Deborah J. MacInnis (2008), "Listening to Strangers: Whose Responses Are Valuable, How Valuable Are They, and Why?" Journal of Marketing Research, 45 (3), 425-436.

Williams, M. Lee (1980), "The Effect of Deliberate Vagueness on Receiver Recall and Agreement," Communication Studies 31 (1), 30-41.

Zheng, Xu, David A. Griffith, Ling Ge, and Uri Benoliel (2020), "Effects of Contract Ambiguity in Interorganizational Governance," Journal of Marketing, 84 (4), 147-167.

Zhou, Qiang (Kris), B.J. Allen, Richard T. Gretz, and Mark B. Houston (2021), "Platform Exploitation: When Service Agents Defect with Customers from Online Service Platforms", Journal of Marketing, forthcoming. 


\section{Table 1. Communication Elements, Links to Uncertainty, and Examples}

\begin{tabular}{|c|c|c|c|}
\hline $\begin{array}{l}\text { Communication } \\
\text { Element }\end{array}$ & Definition & Link to Uncertainty & Example \\
\hline Task information & $\begin{array}{l}\text { A content element of communication; in } \\
\text { service exchanges, it is conveyed through } \\
\text { functional, duty terms (Ma and Dubé } \\
2011 \text { ). The proportion of task terms to the } \\
\text { total number of words in a message } \\
\text { defines the degree of task information. }\end{array}$ & $\begin{array}{l}\text { Greater (lesser) degrees of } \\
\text { task information decrease } \\
\text { (increase) uncertainty }\end{array}$ & 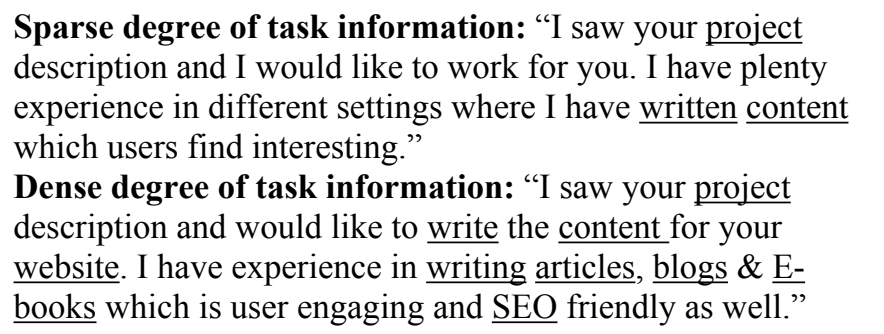 \\
\hline Personal information & $\begin{array}{l}\text { A content element of communication that } \\
\text { is conveyed through self-disclosing terms } \\
\text { (Derlega, Harris, and Chaikin 1973). The } \\
\text { proportion of self-disclosing terms to the } \\
\text { total number of words in a message } \\
\text { defines the degree of personal } \\
\text { information. }\end{array}$ & $\begin{array}{l}\text { Greater (lesser) degrees of } \\
\text { personal information } \\
\text { decrease (increase) } \\
\text { uncertainty }\end{array}$ & $\begin{array}{l}\text { Sparse degree of personal information: "Saw your project } \\
\text { description and would like to write the content for your site. I } \\
\text { have experience in writing articles, blogs \& E-books which is } \\
\text { user engaging and SEO friendly as well." } \\
\text { Dense degree of personal information: "I saw your project } \\
\text { description and I would like to write the content for your site. } \\
\text { I have } 12 \text { years of work experience in copy writing for } \\
\text { articles, blogs \& E-books. I have a Master's in Journalism and } \\
\text { have worked fulltime for companies like Adobe." }\end{array}$ \\
\hline Concreteness & $\begin{array}{l}\text { A manner element of communication, } \\
\text { conveyed by terms that are perceptible, } \\
\text { precise, or specific (Packard and Berger } \\
\text { 2020; Brysbaert, Warriner, and Kuperman } \\
\text { 2014). The proportion of concrete terms } \\
\text { to the total number of words in a message } \\
\text { defines the degree of concreteness. }\end{array}$ & $\begin{array}{l}\text { Greater (lesser) degrees of } \\
\text { concreteness decrease } \\
\text { (increase) uncertainty }\end{array}$ & $\begin{array}{l}\text { Sparse degree of concreteness: "I noticed your project } \\
\text { description and I would like to do work on it. I have plenty of } \\
\text { experience in scripting text, which is engaging, compelling, } \\
\text { and SEO friendly." } \\
\text { Dense degree of concreteness: "I saw your posted project } \\
\text { description on Upwork, and I would like to write the contents } \\
\text { for your website. I have a lot of experience in article and } \\
\text { weblog writing in an SEO friendly fashion." }\end{array}$ \\
\hline Affective intensity & $\begin{array}{l}\text { A manner element of communication that } \\
\text { is conveyed through affective terms } \\
\text { (Hamilton and Hunter 1998). The } \\
\text { proportion of affective terms to the total } \\
\text { number of words in a message defines the } \\
\text { degree of affective intensity. }\end{array}$ & $\begin{array}{l}\text { Greater (lesser) degrees of } \\
\text { intensity decrease (increase) } \\
\text { uncertainty }\end{array}$ & $\begin{array}{l}\text { Sparse degree of affective intensity: "I saw your project } \\
\text { description and I can write the required content for your site. I } \\
\text { have plenty of experience in writing articles, blogs \& E-books } \\
\text { which is user engaging and SEO friendly as well." } \\
\text { Dense degree of affective intensity: "I liked your project } \\
\text { description and would be happy to write the content for your } \\
\text { site. I have great experience in writing articles, blogs \& E- } \\
\text { books which is user engaging and SEO friendly as well." }\end{array}$ \\
\hline
\end{tabular}


Table 2. Predicting the Success of Buyers' Calls for Bids

\begin{tabular}{|c|c|c|c|c|c|c|}
\hline & \multicolumn{3}{|c|}{$\begin{array}{c}\text { Model 1: } \\
\text { Main Effects }\end{array}$} & \multicolumn{3}{|c|}{$\begin{array}{c}\text { Model 2: } \\
\text { Full Model }\end{array}$} \\
\hline & $\beta$ & SE & $95 \% \mathrm{CI}$ & $\beta$ & SE & $95 \% \mathrm{CI}$ \\
\hline \multicolumn{7}{|l|}{ Buyer Communication } \\
\hline Task information & $.123 * *$ & .003 & $.117, .128$ & $.152 * *$ & .003 & $.146, .159$ \\
\hline Personal information & $-.149 * *$ & .004 & $-.157,-.141$ & $-.190 * *$ & .004 & $-.199,-.181$ \\
\hline Concreteness & $.040 * *$ & .003 & $.035, .045$ & $.052 * *$ & .003 & $.046, .057$ \\
\hline Affective intensity & $-.098 * *$ & .007 & $-.112,-.085$ & $-.084 * *$ & .008 & $-.100,-.068$ \\
\hline \multicolumn{7}{|l|}{ Buyer Communication Squared } \\
\hline Task information squared & & & & $-.026 * *$ & .001 & $-.028,-.024$ \\
\hline Personal information squared & & & & $.032 * *$ & .002 & $.029, .035$ \\
\hline Concreteness squared & & & & $-.008 * *$ & .001 & $-.011,-.007$ \\
\hline Affective intensity squared & & & & .001 & .001 & $-.001, .004$ \\
\hline \multicolumn{7}{|l|}{ Controls } \\
\hline Word count & $-.025 * *$ & .003 & $-.031,-.019$ & $-.027 * *$ & .003 & $-.033,-.021$ \\
\hline Buyer experience & $-.033 * *$ & .007 & $-.046,-.020$ & $-.033 * *$ & .007 & $-.046,-.020$ \\
\hline Project payment & $.170 * *$ & .005 & $.159, .181$ & $.168 * *$ & .005 & $.158, .179$ \\
\hline Payment not disclosed & $.073 * *$ & .005 & $.063, .083$ & $.071 * *$ & .005 & $.061, .081$ \\
\hline Project duration & $.116^{* *}$ & .003 & $.110, .122$ & $.117 * *$ & .003 & $.111, .123$ \\
\hline Excess supply of freelancers & $.614^{* *}$ & .004 & $.606, .622$ & $.606 * *$ & .004 & $.598, .613$ \\
\hline \multicolumn{7}{|l|}{ Fixed Effects } \\
\hline Years & \multicolumn{3}{|c|}{ included } & \multicolumn{3}{|c|}{ included } \\
\hline Submarkets & \multicolumn{3}{|c|}{ included } & \multicolumn{3}{|c|}{ included } \\
\hline \multicolumn{7}{|l|}{ Unobserved Heterogeneity } \\
\hline Project characteristics & \multicolumn{3}{|c|}{ included } & \multicolumn{3}{|c|}{ included } \\
\hline \multicolumn{7}{|l|}{ Endogeneity Corrections } \\
\hline Gaussian copulas & \multicolumn{3}{|c|}{ included } & \multicolumn{3}{|c|}{ included } \\
\hline Buyers & \multicolumn{6}{|c|}{49,081} \\
\hline Call for bids & \multicolumn{6}{|c|}{343,796} \\
\hline
\end{tabular}

${ }^{* *} p<.01,{ }^{*} p<.05$. Standardized results. Significance is based on two-tailed tests.

Notes: The dependent variable is the count of all bids received. The sample includes all projects listed by buyers with at least two projects to which at least one freelancer submitted a bid. Effects for years, submarkets, project characteristics, and Gaussian copulas are detailed in Web Appendix Q. 
Table 3. Predicting Freelancers' Bid Success

\begin{tabular}{|c|c|c|c|c|c|c|}
\hline & \multicolumn{3}{|c|}{$\begin{array}{c}\text { Model 3: } \\
\text { Freelancer Communication }\end{array}$} & \multicolumn{3}{|c|}{$\begin{array}{l}\text { Model 4: } \\
\text { Full Model }\end{array}$} \\
\hline & $\beta$ & SE & $95 \% \mathrm{CI}$ & $\beta$ & SE & $95 \% \mathrm{CI}$ \\
\hline & \multicolumn{6}{|c|}{ Freelancer Communication } \\
\hline $\mathrm{y}_{01}$ : Task information & $.014 * *$ & .001 & $.013, .015$ & $.015^{* *}$ & .001 & $.014, .016$ \\
\hline $\mathrm{y}_{02}$ : Personal information & $.018^{* *}$ & .001 & $.016, .019$ & $.017^{* *}$ & .001 & $.016, .017$ \\
\hline $\mathrm{y}_{03}:$ Concreteness & $.030 * *$ & .001 & $.029, .031$ & $.031 * *$ & .001 & $.030, .032$ \\
\hline $\mathrm{y}_{04}$ : Affective intensity & .001 & .001 & $-.001, .003$ & .000 & .001 & $-.002, .001$ \\
\hline \multicolumn{7}{|l|}{ Buyer Communication } \\
\hline $\mathrm{y}_{05}$ : Task information & & & & $-.009^{* *}$ & .000 & $-.009,-.008$ \\
\hline $\mathrm{y}_{06}:$ Personal information & & & & $-.017 * *$ & .000 & $-.018,-.017$ \\
\hline $\mathrm{y}_{07}:$ Concreteness & & & & $-.008^{* *}$ & .000 & $-.009,-.008$ \\
\hline $\mathrm{y}_{08}$ : Affective intensity & & & & $.001 * *$ & .000 & $.001, .002$ \\
\hline \multicolumn{7}{|l|}{ Freelancer Communication Squared } \\
\hline $\mathrm{y}_{09}$ : Task information squared & $-.006^{* *}$ & .000 & $-.006,-.005$ & $-.006^{* *}$ & .000 & $-.007,-.006$ \\
\hline $\mathrm{y}_{10}$ : Personal information squared & $-.005 * *$ & .000 & $-.005,-.004$ & $-.005^{* *}$ & .000 & $-.005,-.004$ \\
\hline $\mathrm{y}_{11}:$ Concreteness squared & $-.006^{* *}$ & .000 & $-.007,-.006$ & $-.007 * *$ & .000 & $-.007,-.007$ \\
\hline $\mathrm{y}_{12}$ : Affective intensity squared & & .000 & $.000, .001$ & $.000 * *$ & .000 & $.000, .001$ \\
\hline \multicolumn{7}{|l|}{ Freelancer-Buyer Interactions } \\
\hline $\mathrm{y}_{13}:$ Task information interaction & & & & $.015^{* *}$ & .000 & $.015, .016$ \\
\hline $\mathrm{y}_{14}$ : Personal information interaction & & & & $-.002 * *$ & .000 & $-.002,-.001$ \\
\hline $\mathrm{y}_{15}:$ Concreteness interaction & & & & $.005^{* *}$ & .000 & $.004, .005$ \\
\hline $\mathrm{y}_{16}:$ Affective intensity interaction & & & & $.020 * *$ & .000 & $.020, .021$ \\
\hline \multicolumn{7}{|l|}{ Buyer Communication Squared } \\
\hline $\mathrm{y}_{17}:$ Task information squared & & & & $.001 * *$ & .000 & $.001, .002$ \\
\hline $\mathrm{y}_{18}$ : Personal information squared & & & & $-.004^{* *}$ & .000 & $-.005,-.004$ \\
\hline $\mathrm{y}_{19}:$ Concreteness squared & & & & $.001 * *$ & .000 & $.001, .001$ \\
\hline $\mathrm{y}_{20}$ : Affective intensity squared & & & & $.000 *$ & .000 & $.000, .000$ \\
\hline \multicolumn{7}{|l|}{ Controls } \\
\hline Word count & $-.022 * *$ & .001 & $-.024,-.021$ & $-.021 * *$ & .001 & $-.022,-.020$ \\
\hline Linguistic style matching & $.051 * *$ & .001 & $.048, .053$ & $.051 * *$ & .001 & $.048, .053$ \\
\hline Freelancer experience & $.002 * *$ & .001 & $.001, .003$ & $.002 * *$ & .001 & $.001, .003$ \\
\hline Freelancer rating & $.010^{* *}$ & .001 & $.009, .010$ & $.010^{* *}$ & .001 & $.009, .010$ \\
\hline Project payment & $-.001 * *$ & .000 & $-.001,-.001$ & $-.001 * *$ & .000 & $-.001,-.001$ \\
\hline Payment not disclosed & $-.028 * *$ & .000 & $-.029,-.028$ & $-.029 * *$ & .000 & $-.030,-.028$ \\
\hline Previous relationship & $.078 * *$ & .001 & $.076, .081$ & $.078 * *$ & .001 & $.075, .080$ \\
\hline Bid price & $-.006 * *$ & .000 & $-.006,-.006$ & $-.006 * *$ & .000 & $-.007,-.006$ \\
\hline Time-to-bid & .001 & .000 & $.000, .001$ & .001 & .000 & $.000, .001$ \\
\hline Late submission & $-.005^{* *}$ & .000 & $-.005,-.004$ & $-.004 * *$ & .000 & $-.005,-.004$ \\
\hline Competition & $-.251^{* *}$ & .007 & $-.265,-.238$ & $-.251^{* *}$ & .007 & $-.264,-.238$ \\
\hline Excess supply of freelancers & $-.044 * *$ & .000 & $-.045,-.043$ & $-.042 * *$ & .000 & $-.043,-.042$ \\
\hline \multicolumn{7}{|l|}{ Fixed Effects } \\
\hline Years & \multirow{2}{*}{\multicolumn{3}{|c|}{$\begin{array}{l}\text { included } \\
\text { included }\end{array}$}} & \multicolumn{3}{|c|}{ included } \\
\hline Submarkets & \multirow{2}{*}{\multicolumn{3}{|c|}{ included }} & \multicolumn{3}{|c|}{ included } \\
\hline \multicolumn{4}{|l|}{ Unobserved Heterogeneity } & & & \\
\hline Project characteristics & \multicolumn{3}{|c|}{ included } & \multicolumn{3}{|c|}{ included } \\
\hline \multicolumn{7}{|l|}{ Endogeneity Corrections } \\
\hline Gaussian copulas & \multicolumn{3}{|c|}{ included } & \multicolumn{3}{|c|}{ included } \\
\hline Freelancers & \multirow{2}{*}{\multicolumn{6}{|c|}{$\begin{array}{c}34,851 \\
2,327,216\end{array}$}} \\
\hline Bids & & & & & & \\
\hline
\end{tabular}

${ }^{* *} p<.01,{ }^{*} p<.05$. Standardized results. Significance is based on two-tailed tests.

Notes: The dependent variable is whether the freelancer is chosen and wins the bidding process. The sample includes all bids by freelancers with at least one winning and at least one losing bid. Effects for years, submarkets, project characteristics, and Gaussian copulas are detailed in Web Appendix Q. 
Table 4. Predicting Freelancers' Price Premium

\begin{tabular}{|c|c|c|c|c|c|c|}
\hline & \multicolumn{3}{|c|}{$\begin{array}{l}\text { Model 5: } \\
\text { Freelancer Communication }\end{array}$} & \multicolumn{3}{|c|}{$\begin{array}{c}\text { Model 6: } \\
\text { Full Model } \\
\end{array}$} \\
\hline & $\boldsymbol{\beta}$ & SE & $95 \% \mathrm{CI}$ & $\beta$ & SE & $95 \% \mathrm{CI}$ \\
\hline & \multicolumn{6}{|c|}{ Freelancer Communication } \\
\hline $\mathrm{y}_{01}:$ Task information & $.023 * *$ & .002 & $.020, .026$ & $.022 * *$ & .002 & $.019, .025$ \\
\hline $\mathrm{y}_{02}:$ Personal information & $.021 * *$ & .002 & $.017, .025$ & $.021 * *$ & .002 & $.017, .026$ \\
\hline $\mathrm{y}_{03}:$ Concreteness & $.006 * *$ & .001 & $.004, .007$ & $.005 * *$ & .001 & $.003, .007$ \\
\hline $\mathrm{y}_{04}:$ Affective intensity & .004 & .003 & $-.002, .010$ & .003 & .003 & $-.003, .009$ \\
\hline \multicolumn{7}{|l|}{ Buyer Communication } \\
\hline $\mathrm{y}_{05}:$ Task information & & & & $.003 *$ & .001 & $.001, .005$ \\
\hline $\mathrm{y}_{06}:$ Personal information & & & & $-.016 * *$ & .002 & $-.019,-.012$ \\
\hline $\mathrm{y}_{07}:$ Concreteness & & & & $-.004 * *$ & .001 & $-.006,-.002$ \\
\hline $\mathrm{y}_{08}:$ Affective intensity & & & & -.001 & .002 & $-.005, .003$ \\
\hline \multicolumn{7}{|l|}{ Freelancer Communication Squared } \\
\hline $\mathrm{y}_{09}$ : Task information squared & -.001 & .001 & $-.002, .000$ & -.001 & .001 & $-.002, .001$ \\
\hline $\mathrm{y}_{10}$ : Personal information squared & $-.004 * *$ & .001 & $-.006,-.002$ & $-.004 * *$ & .001 & $-.006,-.002$ \\
\hline $\mathrm{y}_{11}:$ Concreteness squared & $-.003 * *$ & .001 & $-.004,-.002$ & $-.003 * *$ & .001 & $-.005,-.002$ \\
\hline $\mathrm{y}_{12}$ : Affective intensity squared & .000 & .000 & $-.001, .000$ & .000 & .000 & $-.001, .000$ \\
\hline \multicolumn{7}{|l|}{ Freelancer-Buyer Interactions } \\
\hline $\mathrm{y}_{13}:$ Task information interaction & & & & $.025 * *$ & .003 & $.024, .027$ \\
\hline $\mathrm{y}_{14}$ : Personal information interaction & & & & $-.004 * *$ & .001 & $-.005,-.002$ \\
\hline $\mathrm{y}_{15}:$ Concreteness interaction & & & & $.002 * *$ & .000 & $.001, .002$ \\
\hline $\mathrm{y}_{16}:$ Affective intensity interaction & & & & $.010 * *$ & .003 & $.008, .012$ \\
\hline \multicolumn{7}{|l|}{ Buyer Communication Squared } \\
\hline $\mathrm{y}_{17}:$ Task information squared & & & & $.003 * *$ & .001 & $.001, .004$ \\
\hline $\mathrm{y}_{18}:$ Personal information squared & & & & $.003 * *$ & .001 & $.002, .005$ \\
\hline $\mathrm{y}_{19}:$ Concreteness squared & & & & $-.002 * *$ & .001 & $-.004,-.001$ \\
\hline $\mathrm{y}_{20}:$ Affective intensity squared & & & & $.002 * *$ & .001 & $.000, .003$ \\
\hline \multicolumn{7}{|l|}{ Controls } \\
\hline Word count & $-.014 * *$ & .002 & $-.018,-.011$ & $-.014 * *$ & .002 & $-.018,-.011$ \\
\hline Linguistic style matching & $.022 * *$ & .004 & $.013, .030$ & $.023 * *$ & .004 & $.015, .032$ \\
\hline Freelancer experience & -.001 & .001 & $-.004, .001$ & -.001 & .001 & $-.004, .001$ \\
\hline Freelancer rating & -.001 & .001 & $-.003, .001$ & -.001 & .001 & $-.003, .001$ \\
\hline Project payment & $-.029 * *$ & .010 & $-.049,-.009$ & $-.029 * *$ & .010 & $-.049,-.009$ \\
\hline Previous relationship & $.057 * *$ & .001 & $.054, .059$ & $.056 * *$ & .001 & $.054, .059$ \\
\hline Time-to-bid & $.009 * *$ & .001 & $.007, .012$ & $.009 * *$ & .001 & $.006, .011$ \\
\hline Competition & $-.015 * *$ & .002 & $-.019,-.011$ & $-.015 * *$ & .002 & $-.019,-.011$ \\
\hline Excess supply of freelancers & -.001 & .001 & $-.002, .001$ & -.001 & .001 & $-.002, .001$ \\
\hline \multicolumn{7}{|l|}{ Fixed Effects } \\
\hline Years & \multicolumn{3}{|c|}{ included } & \multicolumn{3}{|c|}{ included } \\
\hline Submarkets & \multicolumn{3}{|c|}{ included } & \multicolumn{3}{|c|}{ included } \\
\hline \multicolumn{7}{|l|}{ Unobserved Heterogeneity } \\
\hline Project characteristics & \multicolumn{3}{|c|}{ included } & \multicolumn{3}{|c|}{ included } \\
\hline \multicolumn{7}{|l|}{ Endogeneity Corrections } \\
\hline Gaussian copulas & \multicolumn{3}{|c|}{ included } & \multicolumn{3}{|c|}{ included } \\
\hline \multicolumn{7}{|l|}{ Sample-Selection Correction } \\
\hline Inverse mills ratio & $-.016 * *$ & .002 & $-.020,-.012$ & $-.016^{* *}$ & .002 & $-.020,-.012$ \\
\hline Freelancers & \multicolumn{6}{|c|}{30,851} \\
\hline Bids & & & 148 &, 158 & & \\
\hline
\end{tabular}

$* * p<.01, * p<.05$. Standardized results. Significance is based on two-tailed tests.

Notes: The dependent variable is price premium for the chosen bid. The sample includes all winning bids for which the payment was disclosed. . Effects for years, submarkets, project characteristics, and Gaussian copulas are detailed in Web Append 


\section{Table 5. Buying and Selling Services in Online Freelance Marketplaces}

\begin{tabular}{|c|c|c|c|}
\hline \multicolumn{4}{|c|}{ How to formulate calls for bids to attract freelancers? } \\
\hline & Bad practice excerpt & Good practice excerpt & Lift in bids \\
\hline $\begin{array}{l}\text { Specify tasks } \\
\text { and skills }\end{array}$ & $\begin{array}{l}\text { "I need a website to showcase the full range of my } \\
\text { fitness workouts." }\end{array}$ & $\begin{array}{l}\text { "I need a website designer who can design a } \\
\text { WordPress website using a WordPress premium } \\
\text { theme." }\end{array}$ & $\begin{array}{l}\text { From } 18 \% \text { to } 29 \% \text { task terms, } \\
\text { resulting in } 5 \% \text { more bids }\end{array}$ \\
\hline $\begin{array}{l}\text { Avoid personal } \\
\text { information }\end{array}$ & $\begin{array}{l}\text { "I have been creating my own classes for almost } 10 \\
\text { years now ... clients tend to especially love my } \\
\text { classes on strength and flexibility. Now I need help } \\
\text { setting up my website." }\end{array}$ & $\begin{array}{l}\text { "I am a Fitness Trainer and need help with building } \\
\text { my website to showcase my mixed services and } \\
\text { home workouts." }\end{array}$ & $\begin{array}{l}\text { From } 9 \% \text { to } 4 \% \text { personal terms, } \\
\text { resulting in } 4 \% \text { more bids }\end{array}$ \\
\hline $\begin{array}{l}\text { Be moderately } \\
\text { concrete }\end{array}$ & $\begin{array}{l}\text { "I require a professional who is savvy in configuring } \\
\text { a stylish website employing a premium theme." }\end{array}$ & $\begin{array}{l}\text { "You should have got very good creative skills but } \\
\text { know how to design for web and also know how to } \\
\text { include calls to actions within a good design." }\end{array}$ & $\begin{array}{l}\text { From } 21 \% \text { to } 26 \% \text { concrete terms, } \\
\text { resulting in } 1 \% \text { more bids }\end{array}$ \\
\hline $\begin{array}{l}\text { Avoid being } \\
\text { affectively } \\
\text { intense }\end{array}$ & $\begin{array}{l}\text { "I have created a fantastic theme but you should be } \\
\text { confident and eager about WordPress and help } \\
\text { optimize." }\end{array}$ & $\begin{array}{l}\text { "The theme and examples will be provided, but you } \\
\text { should also know about WordPress and optimize." }\end{array}$ & $\begin{array}{l}\text { From } 11 \% \text { to } 4 \% \text { affective terms, } \\
\text { resulting in } 4 \% \text { more bids }\end{array}$ \\
\hline \multicolumn{4}{|c|}{ How to formulate successful bids and achieve price premiums? } \\
\hline & Bad practice excerpt & Good practice excerpt & Lift in bid success \\
\hline $\begin{array}{l}\text { Mimic task } \\
\text { description }\end{array}$ & "Dear Sir, would love to work for you..." & $\begin{array}{l}\text { "Hi Gary, I am happy to help you with your fitness } \\
\text { website development and design..." }\end{array}$ & $\begin{array}{l}\text { From } 16 \% \text { to } 25 \% \text { task terms, } \\
\text { resulting in } 7 \% \text { higher bid success } \\
\text { and } 8 \% \text { higher price premium }\end{array}$ \\
\hline $\begin{array}{l}\text { Exceed buyers } \\
\text { who supply } \\
\text { little personal } \\
\text { information }\end{array}$ & $\begin{array}{l}\text { "I am an enthusiastic designer and expert in Web } \\
\text { development..." }\end{array}$ & $\begin{array}{l}\text { "I am a WordPress Freelancer with } 15 \text { years of work } \\
\text { experience..." }\end{array}$ & $\begin{array}{l}\text { From } 6 \% \text { to } 8 \% \text { personal terms, } \\
\text { resulting in } 3 \% \text { higher bid success } \\
\text { and } 4 \% \text { higher price premium }\end{array}$ \\
\hline $\begin{array}{l}\text { Exceed buyers } \\
\text { who are not } \\
\text { concrete }\end{array}$ & $\begin{array}{l}\text { "I have great skills and plenty of fantastic experience } \\
\text { in creating relevant websites..." }\end{array}$ & $\begin{array}{l}\text { "I have worked on several similar projects, designing } \\
\text { websites using a WordPress including premium } \\
\text { themes and I can deliver to a tight schedule..." }\end{array}$ & $\begin{array}{l}\text { From } 24 \% \text { to } 30 \% \text { concrete terms, } \\
\text { resulting in } 7 \% \text { higher bid success } \\
\text { (but no effect on price premium) }\end{array}$ \\
\hline $\begin{array}{l}\text { Mimic the } \\
\text { buyer's } \\
\text { affective } \\
\text { intensity }\end{array}$ & $\begin{array}{l}\text { "The content will be creative and fun, attractive, and } \\
\text { thoughtful..." }\end{array}$ & $\begin{array}{l}\text { "Website content that I produce will be creative and } \\
\text { include original designs..." }\end{array}$ & $\begin{array}{l}\text { From } 18 \% \text { to } 6 \% \text { affective terms } \\
\text { resulting in } 11 \% \text { higher bid success } \\
\text { and } 7 \% \text { higher price premium }\end{array}$ \\
\hline
\end{tabular}

Notes: Web Appendix S provides the full call for bids and bids examples which we used for calculating the degrees of each communicative principle and the corresponding expected lift success. We used the "good practice" call for bids example to devise the bad and good examples for the corresponding freelance bid. 
Figure 1. Bidding Process and Conceptual Framework

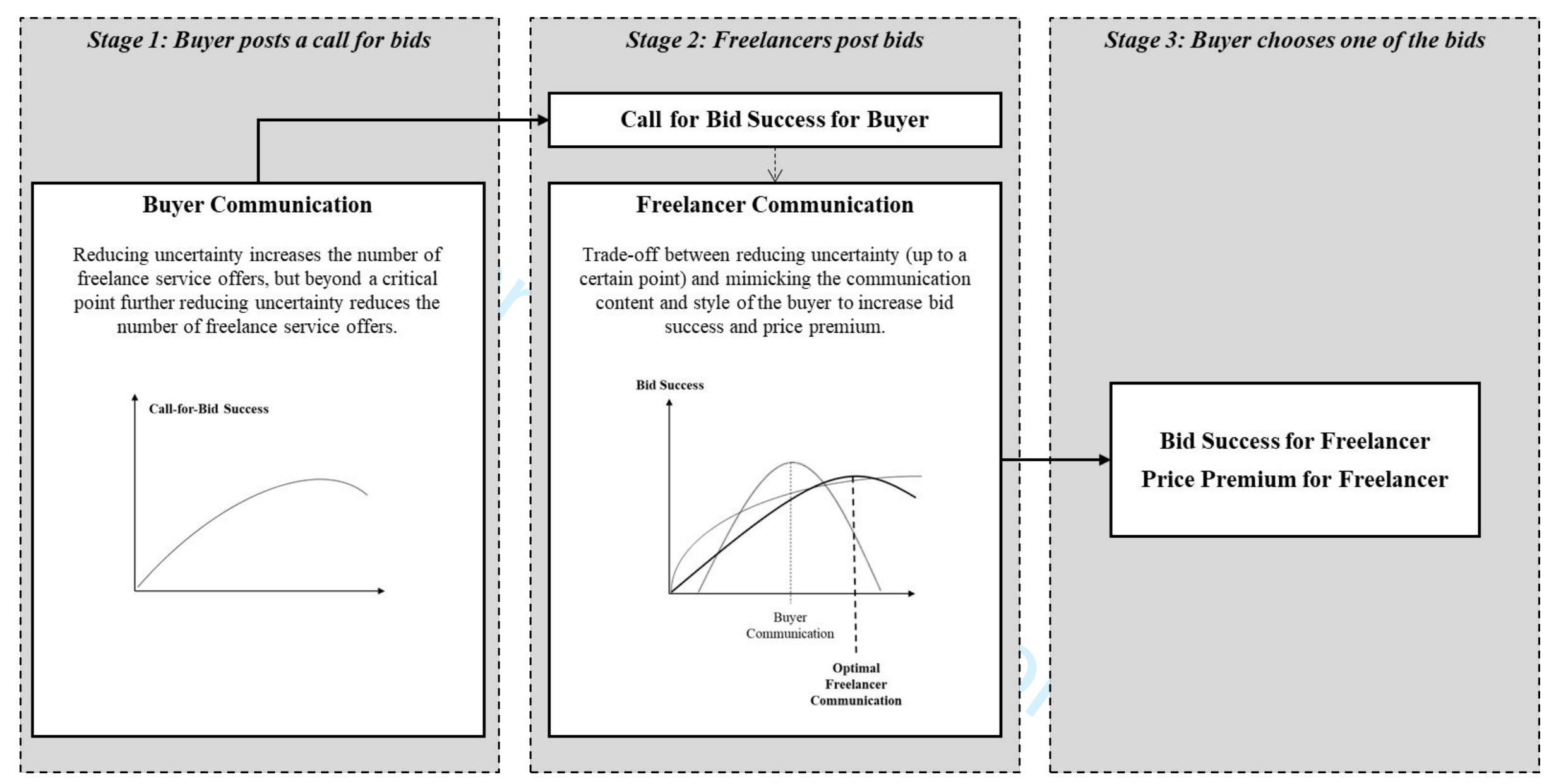




\section{Figure 2. Effect of Buyers' Communication on Calls for Bids Success}

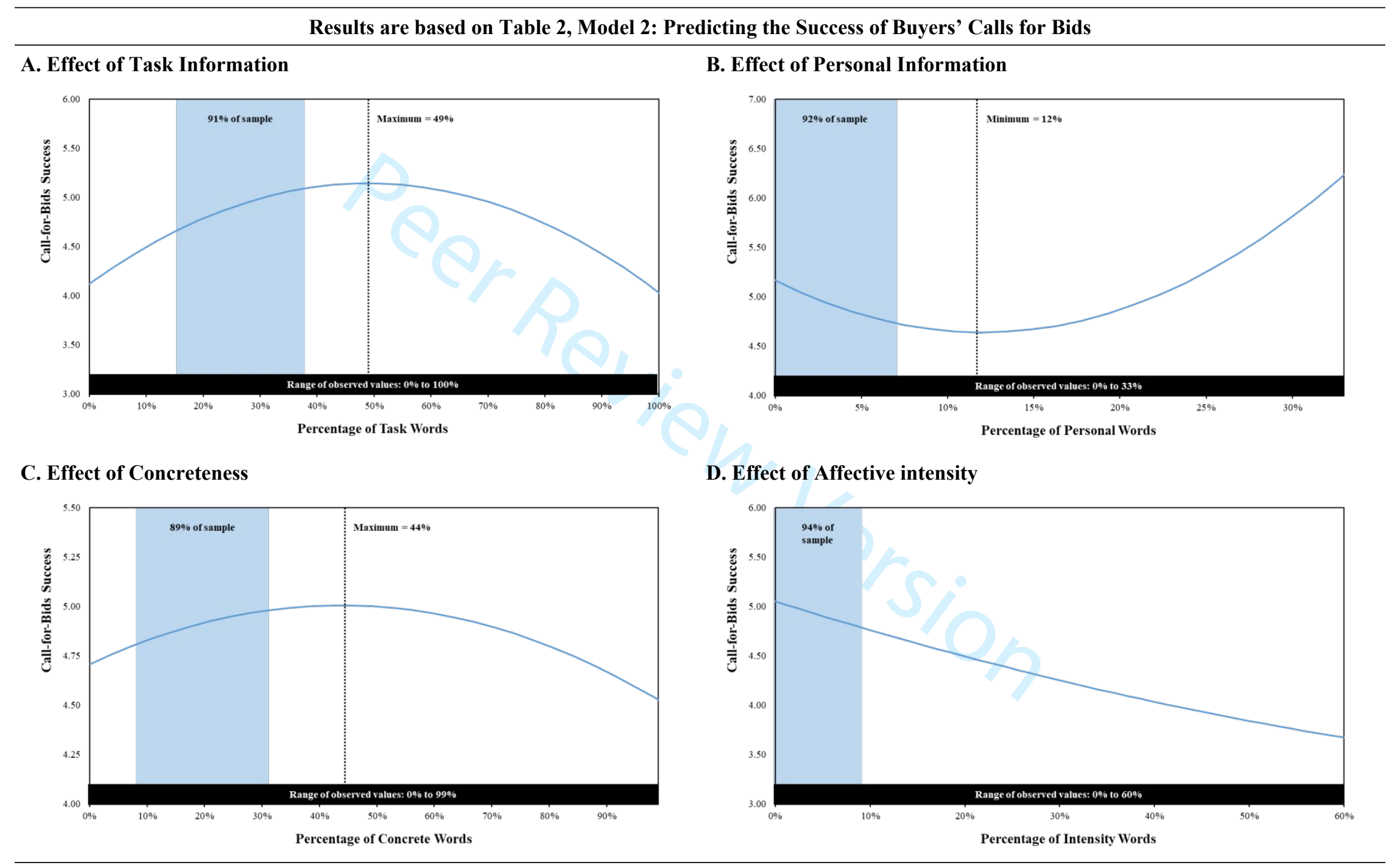

Note: The blue area includes all values within $\pm 1.5 \mathrm{SD}$ from the mean. 


\section{Figure 3. Response Surfaces for Bid Success and Price Premium}

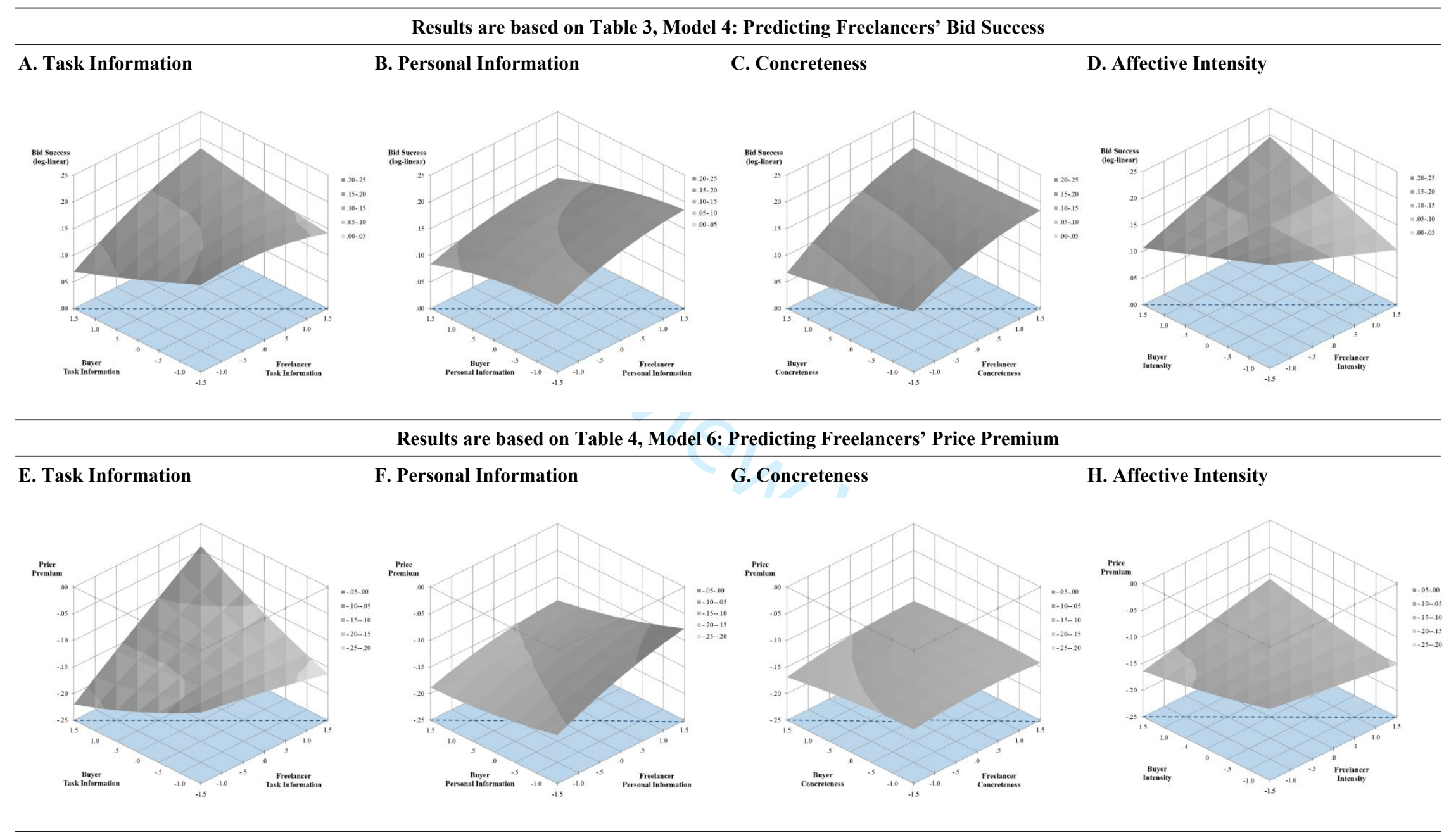

Notes: We detail the response surfaces in the Web Appendix. Web Appendix L displays similarity and dissimilarity effects for bid success, Web Appendix M displays simple slope analyses of low vs. high levels of buyers' communication for bid success, Web Appendix O displays similarity and dissimilarity effects for price premium, Web Appendix P displays simple slope analyses of low vs. high levels of buyers' communication for price premium. 


\section{WEB APPENDIX \\ Communication in the Gig Economy: Buying and Selling in Online Freelance Marketplaces}

Stephan Ludwig (stephan.ludwig@unimelb.edu.au), Dennis Herhausen, Dhruv Grewal, Liliana Bove, Sabine Benoit, Ko de Ruyter, Peter Urwin.

"These materials have been supplied by the authors to aid in the understanding of their paper. The AMA is sharing these materials at the request of the authors."

WA\#A: Main Empirical Marketing Studies on B2B Communication Aspects ......................1

WA\#B: Main Studies Using Automated Text-Analysis to Investigate Communication ...........3

WA\#C: Definitions, Representative Articles, and Operationalizations of All Measures...........5

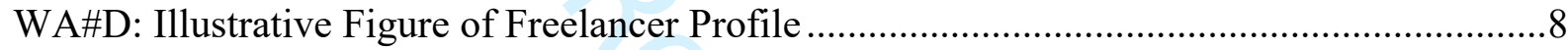

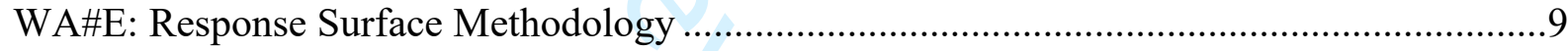

WA\#F: Manual Validity Checks of Text Analysis Approach ............................................12

WA\#G: Experimental Evidence of Uncertainty Reduction...............................................15

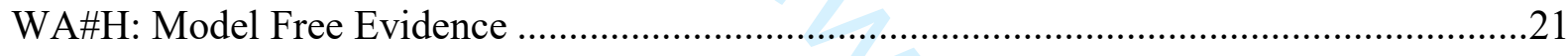

WA\#I: Latent Dirichlet Allocation to Account for Project Characteristics...........................23

WA\#J: Descriptive Statistics and Correlations..................................................................25

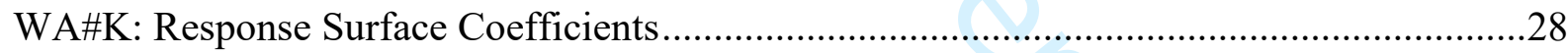

WA\#L: Effect of Matching the Buyers' Communication on Bid Success ............................29

WA\#M: Low vs. High Levels of Buyers' Communication and Bid Success..........................30

WA\#N: Results for the Selection Model .................................................................. 31

WA\#O: Effect of Matching the Buyers' Communication on Price Premium .........................32

WA\#P: Low vs. High Levels of Buyers' Communication and Price Premium ......................33

WA\#Q: Additional Effects for All Analyses ......................................................................

WA\#R: Robustness Test: Predicting Freelancers’ Bid Success .........................................37

WA\#S: Illustrative Examples of Bad and Good Practice Calls for Bids and Bids..................38

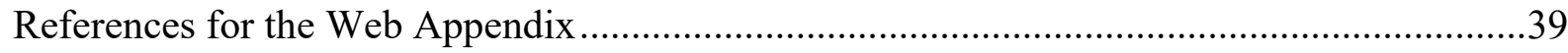




\section{WA\#A: Main Empirical Marketing Studies on B2B Communication Aspects}

\begin{tabular}{|c|c|c|c|c|c|}
\hline Authors & Context & Communication & Dependent Variables & Communication Aspects & Data Source \\
\hline $\begin{array}{l}\text { Agnihotri, Rapp, and Trainor } \\
\text { (2009) }\end{array}$ & Offline & Seller $\rightarrow$ Buyer & Buyers' satisfaction $(\mathrm{P})$ & Timeliness and relevance of communication $(\mathrm{P})$ & Survey \\
\hline $\begin{array}{l}\text { Ahearne, Jelinek, and Jones } \\
\text { (2007) }\end{array}$ & Offline & Seller $\rightarrow$ Buyer & Buyers' satisfaction $(\mathrm{P})$ & Efficacy of communication $(\mathrm{P})$ & Survey \\
\hline Anderson and Narus (1990) & Offline & $\begin{array}{l}\text { Buyer } \rightarrow \text { Seller } \\
\text { Seller } \rightarrow \text { Buyer }\end{array}$ & $\begin{array}{l}\text { Sellers' cooperation }(\mathrm{P}) \\
\text { Buyers' cooperation and trust } \\
\text { (P) }\end{array}$ & Efficacy of communication (P) & Survey \\
\hline $\begin{array}{l}\text { Anderson, Lodish, and Weitz } \\
\text { (1987) }\end{array}$ & Offline & Buyer $\rightarrow$ Seller & $\begin{array}{l}\text { Sellers' time allocated to buyer } \\
\text { (B) }\end{array}$ & $\begin{array}{l}\text { Frequency of positive feedback, formality and detail in } \\
\text { communication }(\mathrm{P})\end{array}$ & Survey \\
\hline $\begin{array}{l}\text { Bialaszewski and Giallourakis } \\
(1985)\end{array}$ & Offline & Buyer $\rightarrow$ Seller & Sellers' trust in buyer $(\mathrm{P})$ & Efficacy of communication $(\mathrm{P})$ & Survey \\
\hline Cannon and Homburg (2001) & Offline & Seller $\rightarrow$ Buyer & Buyers' transaction costs $(\mathrm{P})$ & Frequency and amount of communication $(\mathrm{P})$ & Survey \\
\hline Comstock and Higgins (1997) & Offline & Seller $\rightarrow$ Buyer & Buyer's satisfaction $(\mathrm{P})$ & $\begin{array}{l}\text { Cooperativeness, apprehensiveness, socialness and } \\
\text { competitiveness in communication }(\mathrm{P})\end{array}$ & Survey \\
\hline Dion and Notarantonio (1992) & Offline & Seller $\rightarrow$ Buyer & Sellers' performance (B) & $\begin{array}{l}\text { Contentious, open, dramatic, precise, relaxed, friendly, } \\
\text { dominant, attentive, animated and impressionistic } \\
\text { communication }(\mathrm{P})\end{array}$ & $\begin{array}{l}\text { Survey and } \\
\text { experiment }\end{array}$ \\
\hline $\begin{array}{l}\text { Guiltnan, Rejab, and Rodgers } \\
\text { (1980) }\end{array}$ & Offline & Seller $\rightarrow$ Buyer & Buyers' coordination $(\mathrm{P})$ & Efficacy of communication (P) & Survey \\
\hline Homburg et al. (2002) & Offline & Seller $\rightarrow$ Buyer & Buyers' satisfaction $(\mathrm{P})$ & Frequency of information sharing $(\mathrm{P})$ & Survey \\
\hline $\begin{array}{l}\text { Homburg, Giering, and } \\
\text { Menon (2003) }\end{array}$ & Offline & Seller $\rightarrow$ Buyer & $\begin{array}{l}\text { Buyers' satisfaction }(\mathrm{P}) \text { and } \\
\text { loyalty }(\mathrm{P})\end{array}$ & Frequency of communication $(\mathrm{P})$ & Survey \\
\hline $\begin{array}{l}\text { Homburg, Muller, and } \\
\text { Klarmann (2011) }\end{array}$ & Offline & Seller $\rightarrow$ Buyer & Buyers' loyalty $(\mathrm{P})$ & Task and interaction orientation in communication $(\mathrm{P})$ & Survey \\
\hline Hossain and Chonko (2018) & Offline & Seller $\rightarrow$ Buyer & $\begin{array}{l}\text { Buyers' loyalty }(\mathrm{P}) \text { and } \\
\text { performance }(\mathrm{P})\end{array}$ & Frequency and formality of communication $(\mathrm{P})$ & Survey \\
\hline Hung and Lin (2013) & Offline & Seller $\rightarrow$ Buyer & Buyers' satisfaction $(\mathrm{P})$ & $\begin{array}{l}\text { Regularity, timeliness and quality of communication } \\
\text { (P) }\end{array}$ & Survey \\
\hline Jaramillo and Grisaffe (2009) & Offline & Seller $\rightarrow$ Buyer & Sellers' sales performance (B) & Seller's customer orientation and adaptive selling $(\mathrm{P})$ & $\begin{array}{l}\text { Survey and } \\
\text { objective data }\end{array}$ \\
\hline Joshi (2009) & Offline & Buyer $\rightarrow$ Seller & $\begin{array}{l}\text { Sellers' knowledge }(\mathrm{P}) \text {, } \\
\text { commitment }(\mathrm{P}) \text {, and } \\
\text { performance }(\mathrm{P})\end{array}$ & $\begin{array}{l}\text { Frequency, formality, reciprocity, rationality in } \\
\text { communication }(\mathrm{P})\end{array}$ & Survey \\
\hline Kozlenkova et al. (2017) & Online & Seller $\rightarrow$ Buyer & $\begin{array}{l}\text { Buyer's relationship formation } \\
\text { (B) }\end{array}$ & $\begin{array}{l}\text { Bilateral communication (B) } \\
\text { Number of interactions (B) }\end{array}$ & Objective data \\
\hline
\end{tabular}


WA p. 2

\begin{tabular}{|c|c|c|c|c|c|}
\hline $\begin{array}{l}\text { Kumar and Venkatesan } \\
(2005)\end{array}$ & $\begin{array}{l}\text { Online \& } \\
\text { Offline }\end{array}$ & $\begin{array}{l}\text { Buyer } \rightarrow \text { Seller } \\
\text { Seller } \rightarrow \text { Buyer }\end{array}$ & $\begin{array}{l}\text { Revenue, Share of Wallet, Past } \\
\text { Customer Value, Likelihood of } \\
\text { Staying Active (B) }\end{array}$ & $\begin{array}{l}\text { Number of times the customer contacted the supplier } \\
\text { via the internet vs. offline (B) }\end{array}$ & Objective data \\
\hline Lawrence et al. (2019) & $\begin{array}{l}\text { Online \& } \\
\text { Offline }\end{array}$ & Seller $\rightarrow$ Buyer & Sales revenue $(\mathrm{B})$ & $\begin{array}{l}\text { Number of interpersonal contact between customer and } \\
\text { salesperson (B) }\end{array}$ & $\begin{array}{l}\text { Survey and } \\
\text { objective data }\end{array}$ \\
\hline $\begin{array}{l}\text { McFarland, Challagalla, and } \\
\text { Shervani (2006) }\end{array}$ & Offline & Seller $\rightarrow$ Buyer & Sellers' performance $(\mathrm{P})$ & $\begin{array}{l}\text { Task, self and interaction orientation in communication } \\
\text { (P) }\end{array}$ & Survey \\
\hline Mohr and Sohi 1995 & Offline & Seller $\rightarrow$ Buyer & Buyers' satisfaction $(\mathrm{P})$ & $\begin{array}{l}\text { Amount, frequency, adequate, timely, accurate, } \\
\text { complete and credible communication }(\mathrm{P})\end{array}$ & Survey \\
\hline Mohr, Fisher, and Nevin 1996 & Offline & Seller $\rightarrow$ Buyer & $\begin{array}{l}\text { Buyers' satisfaction and } \\
\text { commitment }(\mathrm{P})\end{array}$ & $\begin{array}{l}\text { Frequency, bidirectionality, formality and noncoercive } \\
\text { of communication }(\mathrm{P})\end{array}$ & Survey \\
\hline Authors & Context & Communication & Dependent Variables & Communication Aspects & Data Source \\
\hline Morgan and Hunt (1994) & Offline & Seller $\rightarrow$ Buyer & $\begin{array}{l}\text { Buyers' trust, commitment, } \\
\text { uncertainty, cooperation }(\mathrm{P})\end{array}$ & Efficacy and timeliness of communication $(\mathrm{P})$ & Survey \\
\hline Murphy and Sashi (2018) & Offline & Seller $\rightarrow$ Buyer & $\begin{array}{l}\text { Buyers' satisfaction with seller } \\
\text { (P) }\end{array}$ & $\begin{array}{l}\text { Frequency, rationality and reciprocity in } \\
\text { communication }(\mathrm{P})\end{array}$ & Survey \\
\hline $\begin{array}{l}\text { Palmatier, Dant, and Grewal } \\
\text { (2007) }\end{array}$ & Offline & $\begin{array}{l}\text { Buyer } \rightarrow \text { Seller } \\
\text { Seller } \rightarrow \text { Buyer }\end{array}$ & $\begin{array}{l}\text { Buyers' commitment, trust, } \\
\text { interdependence, opportunism, } \\
\text { investments, norms (P) }\end{array}$ & $\begin{array}{l}\text { Timeliness, completeness and accuracy in } \\
\text { communication }(\mathrm{P})\end{array}$ & Survey \\
\hline Palmatier et al. (2006) & Offline & Seller $\rightarrow$ Buyer & $\begin{array}{l}\text { Buyers' commitment, trust, } \\
\text { satisfaction, relational quality } \\
\text { (P) }\end{array}$ & $\begin{array}{l}\text { Amount, frequency and the quality of communication } \\
\text { (P) }\end{array}$ & Meta-analysis \\
\hline Román and Martín (2008) & Offline & Seller $\rightarrow$ Buyer & $\begin{array}{l}\text { Sales volume, perceived service } \\
\text { quality and buyer satisfaction } \\
\text { (P) }\end{array}$ & $\begin{array}{l}\text { Call frequency in the supplier-customer relationship (B) } \\
\text { Call frequency (B) }\end{array}$ & $\begin{array}{l}\text { Survey and } \\
\text { objective data }\end{array}$ \\
\hline Schmitz et al. (2020) & $\begin{array}{l}\text { Online \& } \\
\text { Offline }\end{array}$ & Seller $\rightarrow$ Buyer & Sales (B) & Personal communication vs. phone communication (B) & Objective data \\
\hline $\begin{array}{l}\text { Singh, Marinova and Singh } \\
(2020)\end{array}$ & Online & Seller $\rightarrow$ Buyer & $\begin{array}{l}\text { Buyer attention }(\mathrm{P}) \text { and sales } \\
\text { (B) }\end{array}$ & $\begin{array}{l}\text { Recommendations, promises, assertiveness, info } \\
\text { sharing via emails (B) }\end{array}$ & Objective data \\
\hline $\begin{array}{l}\text { Zhang, Netzer, and Ansari } \\
\text { (2014) }\end{array}$ & $\begin{array}{l}\text { Online \& } \\
\text { Offline }\end{array}$ & Buyer $\rightarrow$ Seller & $\begin{array}{l}\text { Bid probability (B) and Accept } \\
\text { probability (B) }\end{array}$ & Direct order vs. quote request (B) & Objective data \\
\hline This study & Online & $\begin{array}{l}\text { Buyer } \rightarrow \text { Seller } \\
\text { Seller } \rightarrow \text { Buyer }\end{array}$ & $\begin{array}{l}\text { Call for bid success and bid } \\
\text { success }(B), \text { uncertainty } \\
\text { reduction }(P)\end{array}$ & $\begin{array}{l}\text { Degree of task information, personal information, } \\
\text { concreteness, affective intensity, and mimicry in } \\
\text { communication }\end{array}$ & $\begin{array}{l}\text { Objective data } \\
\text { and experiment }\end{array}$ \\
\hline
\end{tabular}

Note: Measures are classified into perceptions (P), intentions (I), and behaviors (B). Objective data comprises behavioral and communication data as naturally observed, surveys can be both cross-sectional and longitudinal. 
WA\#B: Main Studies Using Automated Text-Analysis to Investigate Communication

\begin{tabular}{|c|c|c|c|c|c|}
\hline \multirow[b]{2}{*}{ Authors } & \multirow[b]{2}{*}{$\begin{array}{l}\text { Context: } \\
\text { Text Type }\end{array}$} & \multirow{2}{*}{$\begin{array}{c}\text { Type of Flow } \\
\text { C = Consumer } \\
\text { B = Business }\end{array}$} & \multirow{2}{*}{$\begin{array}{c}\text { DVs } \\
\text { Perception (P) } \\
\text { Intentions (I) } \\
\text { Behavior (B) }\end{array}$} & \multicolumn{2}{|c|}{ Independent and Moderating Variables } \\
\hline & & & & $\begin{array}{c}\text { Main } \\
\text { Communication } \\
\text { Aspects } \\
\end{array}$ & $\begin{array}{c}\text { Uncertainty } \\
\text { Reduction } \\
\text { Aspects }\end{array}$ \\
\hline $\begin{array}{l}\text { Barasch and } \\
\text { Berger (2014) }\end{array}$ & $\begin{array}{l}\text { Informational: } \\
\text { customer } \\
\text { reviews, WOM }\end{array}$ & $\mathrm{C} \rightarrow \mathrm{C}$ & $\begin{array}{l}\text { Self-presentation in } \\
\text { language }(B)\end{array}$ & $\begin{array}{l}\text { Self- versus other- } \\
\text { orientation in } \\
\text { communication }\end{array}$ & no \\
\hline $\begin{array}{l}\text { Herhausen et } \\
\text { al. (2019) }\end{array}$ & $\begin{array}{l}\text { Informational: } \\
\text { WOM }\end{array}$ & $\mathrm{C} \rightarrow \mathrm{C}$ & $\begin{array}{l}\text { Virality consumer } \\
\text { posts }(\mathrm{B})\end{array}$ & $\begin{array}{l}\text { Emotions and emotional } \\
\text { arousal in communication }\end{array}$ & no \\
\hline $\begin{array}{l}\text { Homburg, } \\
\text { Ehm and Artz } \\
(2015)\end{array}$ & $\begin{array}{l}\text { Informational: } \\
\text { WOM and } \\
\text { company } \\
\text { reaction }\end{array}$ & $\begin{array}{l}\mathrm{C} \rightarrow \mathrm{C} \\
\mathrm{B} \rightarrow \mathrm{C}\end{array}$ & $\begin{array}{l}\text { Consumer sentiment } \\
\text { (P) }\end{array}$ & $\begin{array}{l}\text { Relative firm engagement in } \\
\text { consumer communication }\end{array}$ & no \\
\hline
\end{tabular}

Kim and

Transactional: $\mathrm{B} \rightarrow \mathrm{C}$

Kumar (2018) direct marketing

Kronrod and

Danziger

(2013)

Informational: $\mathrm{C} \rightarrow \mathrm{C}$ customer $\quad \mathrm{B} \rightarrow \mathrm{C}$ reviews, advertisements

Ludwig et al. Informational: $\mathrm{C} \rightarrow \mathrm{C}$ (2013) customer reviews

Ma, Sun and Informational: $\mathrm{C} \rightarrow \mathrm{C}$

Kekre (2015) WOM $\quad$ B $\rightarrow$ C

Moon and Kamakura (2017) Nguyen and Chaudhuri (2019)

Informational: $\quad \mathrm{C} \rightarrow \mathrm{C}$ customer reviews

Transactional: $\quad \mathrm{C} \rightarrow \mathrm{C}$ product (pre-) $\quad \mathrm{B} \rightarrow \mathrm{C}$ announcements, WOM

Pitt, Mulvey Informational: $\mathrm{C} \rightarrow \mathrm{C}$ and Kietzmann (2018) customer reviews

Rocklage and Informational: $\mathrm{C} \rightarrow \mathrm{C}$ Fazio (2015) customer reviews

Sonnier, Transactional: $\mathrm{C} \rightarrow \mathrm{C}$ McAlister and WOM

Rutz (2011)

Timoshenko and Hauser

Informational: $\mathrm{C} \rightarrow \mathrm{C}$ customer reviews
Customer purchase

behavior (B)

Economic and relational content in communication

Consumer product, review-, Figurative versus literal

no advertisement attitude (P), and product choice (B)

Online retail site Affect in- and linguistic style no conversion rates (B) of communication

Relationship state (P), Complaints versus no voice (B), friends' compliments

influence on communication (B)

Product position (P) Writing style of reviewer no and features $(\mathrm{P})$ on perceptual map

Consumer online Positive sentiment, content engagement (B) and richness, aggregated product sales (B)

Consumer sentiments Emotions in communication no (P)

Consumer intention Emotions and emotional no to share message (I) extremity in communication

Aggregated product Sentiment in communication no sales (B)

Customer needs (P) Informative versus non- no informative content in communication 
WA p. 4

\begin{tabular}{|c|c|c|c|c|c|}
\hline $\begin{array}{l}\text { Van Laer et al. } \\
\text { (2018) }\end{array}$ & $\begin{array}{l}\text { Informational: } \\
\text { customer } \\
\text { reviews }\end{array}$ & $\mathrm{C} \rightarrow \mathrm{C}$ & $\begin{array}{l}\text { Consumer review } \\
\text { helpfulness (B) }\end{array}$ & $\begin{array}{l}\text { Narrativity of } \\
\text { communication }\end{array}$ & no \\
\hline $\begin{array}{l}\text { Villarroel } \\
\text { Ordenes et al. } \\
\text { (2018) }\end{array}$ & $\begin{array}{l}\text { Informational: } \\
\text { WOM }\end{array}$ & $\mathrm{C} \rightarrow \mathrm{C}$ & $\begin{array}{l}\text { Consumer sharing } \\
\text { and liking of message } \\
\text { (B) }\end{array}$ & $\begin{array}{l}\text { Intentions in communication } \\
\text { (i.e., assertive, expressive, or } \\
\text { directive) }\end{array}$ & no \\
\hline $\begin{array}{l}\text { Villarroel } \\
\text { Ordenes et al. } \\
\text { (2017) }\end{array}$ & $\begin{array}{l}\text { Informational: } \\
\text { customer } \\
\text { reviews }\end{array}$ & $\mathrm{C} \rightarrow \mathrm{C}$ & $\begin{array}{l}\text { Consumer sentiment } \\
\text { (P) }\end{array}$ & Sentiment in communication & no \\
\hline $\begin{array}{l}\text { Yin, Bond and } \\
\text { Zhang (2017) }\end{array}$ & $\begin{array}{l}\text { Informational: } \\
\text { customer } \\
\text { reviews }\end{array}$ & $\mathrm{C} \rightarrow \mathrm{C}$ & $\begin{array}{l}\text { Consumer review } \\
\text { helpfulness }(\mathrm{P})\end{array}$ & $\begin{array}{l}\text { Emotions and emotional } \\
\text { arousal in communication }\end{array}$ & 0 \\
\hline $\begin{array}{l}\text { Zhang, Moe } \\
\text { and Schweidel } \\
\text { (2017) }\end{array}$ & $\begin{array}{l}\text { Informational: } \\
\text { WOM }\end{array}$ & $\mathrm{C} \rightarrow \mathrm{C}$ & $\begin{array}{l}\text { Consumer } \\
\text { rebroadcasting } \\
\text { of messages (B) }\end{array}$ & Content of message & 10 \\
\hline
\end{tabular}

\begin{tabular}{|c|c|c|c|c|c|}
\hline \multirow[b]{2}{*}{ Authors } & \multirow[b]{2}{*}{$\begin{array}{c}\text { Context: } \\
\text { Text Type }\end{array}$} & \multirow{2}{*}{$\begin{array}{l}\text { Type of Flow } \\
\begin{array}{l}\text { C = Consumer } \\
\text { B = Business }\end{array}\end{array}$} & \multirow{2}{*}{$\begin{array}{c}\text { DVs } \\
\text { Perception (P) } \\
\text { Intentions (I) } \\
\text { Behavior (B) }\end{array}$} & \multicolumn{2}{|c|}{ Independent and Moderating Variables } \\
\hline & & & & $\begin{array}{c}\text { Main } \\
\text { Communication } \\
\text { Aspects }\end{array}$ & $\begin{array}{c}\text { Uncertainty } \\
\text { Reduction } \\
\text { Aspects }\end{array}$ \\
\hline
\end{tabular}

\begin{tabular}{|c|c|c|c|c|c|}
\hline $\begin{array}{l}\text { Packard and } \\
\text { Berger }(2020)\end{array}$ & $\begin{array}{l}\text { Informational: } \\
\text { customer service } \\
\text { phone calls and } \\
\text { email }\end{array}$ & $\mathrm{B} \rightarrow \mathrm{C}$ & $\begin{array}{l}\text { Satisfaction }(\mathrm{P}) \text {, } \\
\text { Willing to purchase } \\
\text { (I), and } \\
\text { Purchase (B) }\end{array}$ & Concreteness & yes \\
\hline $\begin{array}{l}\text { Packard, More } \\
\text { and McFerran } \\
(2018)\end{array}$ & $\begin{array}{l}\text { Informational: } \\
\text { customer } \\
\text { queries, } \\
\text { company } \\
\text { answers }\end{array}$ & $\begin{array}{l}\mathrm{C} \rightarrow \mathrm{B} \\
\mathrm{B} \rightarrow \mathrm{C}\end{array}$ & $\begin{array}{l}\text { Consumer purchase } \\
\text { (B) }\end{array}$ & $\begin{array}{l}\text { Customer orientation in } \\
\text { communication }\end{array}$ & no \\
\hline $\begin{array}{l}\text { Singh, } \\
\text { Marinova and } \\
\text { Singh (2020) }\end{array}$ & $\begin{array}{l}\text { Transactional: } \\
\text { Email }\end{array}$ & $\mathrm{B} \rightarrow \mathrm{B}$ & $\begin{array}{l}\text { Buyer attention }(\mathrm{P}) \\
\text { and sales }(\mathrm{B})\end{array}$ & $\begin{array}{l}\text { Recommendations, } \\
\text { promises, assertiveness, info } \\
\text { sharing via emails }\end{array}$ & no \\
\hline This study & $\begin{array}{l}\text { Transactional: } \\
\text { Call for bids } \\
\text { and Bids }\end{array}$ & $B \leftrightarrow B$ & $\begin{array}{l}\text { Number of bids }(B), \\
\text { Winning bid }(B), \\
\text { Price Premium (B) }\end{array}$ & $\begin{array}{l}\text { Communication strategies to } \\
\text { manage uncertainty }\end{array}$ & yes \\
\hline
\end{tabular}




\section{WA\#C: Definitions, Representative Articles, and Operationalizations of All Measures}

\begin{tabular}{|c|c|c|c|}
\hline Construct & Definition & $\begin{array}{l}\text { Representative } \\
\text { Articles }\end{array}$ & Operationalization \\
\hline \multicolumn{4}{|c|}{ Dependent Variables } \\
\hline $\begin{array}{l}\text { Call For Bid } \\
\text { Success }\end{array}$ & $\begin{array}{l}\text { The number of } \\
\text { freelancers who submit a } \\
\text { bid application }\end{array}$ & Horton (2019) & $\begin{array}{l}\text { The number of freelancers who submit a bid to the } \\
\text { call for bids. }\end{array}$ \\
\hline Bid Success & $\begin{array}{l}\text { Whether or not the } \\
\text { freelancer's bid is } \\
\text { successful }\end{array}$ & $\begin{array}{l}\text { Hong and } \\
\text { Pavlou (2017) }\end{array}$ & $\begin{array}{l}\text { Whether (1) or not }(0) \text { a freelancer was chosen by } \\
\text { the buyer and thus wins the bidding process. }\end{array}$ \\
\hline Price Premium & $\begin{array}{l}\text { The monetary amount in } \\
\text { excess of the buyer's } \\
\text { original payment offer } \\
\text { for a certain freelance } \\
\text { service project }\end{array}$ & $\begin{array}{l}\text { Singh and } \\
\text { Sirdeshmukh } \\
(2000)\end{array}$ & $\begin{array}{l}\text { The percentage by which the final (accepted) bid } \\
\text { price for the project exceeds (or falls short of) the } \\
\text { buyer's original payment offered (her benchmark } \\
\text { price) }\end{array}$ \\
\hline
\end{tabular}

Communication Content

Task Information

Personal Information
Task information is a content element of communication, that, in the service exchange context, is conveyed through lexical terms on functional service duties (Ma and Dubé 2011)

The proportion of lexical task terms to the total number of words in a message, defines the degree of task information (Bradac, Hopper, and Weimann 1989; Berger et al. 2020).

Personal information is a content element of communication, that is conveyed through lexical self-disclosing terms about the self (Derlega, Harris, and Chaikin 1973)

The proportion of lexical self-terms to the total number of words in a message, defines the degree of personal information (Bradac, Hopper, and Weimann, 1989; Berger et al. 2020).

\section{N.A. \\ Proportion of context specific task descriptor words (using freelancers' service skill tags which list key words freelancers use to describe the service tasks they offer (e.g., "Python Developer", "Designer", "Illustrator")) to total words in the message.}

Pennebaker and Proportion of first-person singular pronouns (e.g., Stone (2001) "I", "me") to total words in the message (using the "I" LIWC dictionary; Tausczik and Pennebaker 2010). 
WA p. 6

Communication Style

Concreteness

Concreteness is a manner element of communication, that is conveyed through lexical terms which are perceptible, precise, or specific (Packard and Berger 2020; Brysbaert, Warriner, and Kuperman 2014)

The proportion of lexical concrete terms to the total number of words in a message, defines the degree of concreteness (Bradac, Hopper, and Weimann, 1989; Berger et al. 2020).

Affective Intensity Affective intensity is a manner element of communication, that is conveyed through lexical terms which are affective (Hamilton and Hunter 1998)

The proportion of lexical emotional terms to the total number of words in a message, defines the degree of intensity (Bradac, Hopper, and Weimann, 1989; Berger et al. 2020).
Brysbaert et al. Proportion of concrete words to total words in the (2014) message (using all the relatively concrete lemmas $(=>3)$ in the dictionary by Brysbaert et al. 2014).
Hamilton and Proportion of affect words (e.g. "problematic", Hunter (1998) "great", "easy") to total words in the message (using the "affect" LIWC dictionary; Tausczik and Pennebaker 2010).

\footnotetext{
Controls for buyers' Call for bids Success

Word Count The extent to which a Herhausen et al. Sum of words in a text. text provides information (2019)

Buyer Experience The number of projects a Hong and The number of projects a buyer had already buyer already had Pavlou (2017) purchased on the purchased on the platform prior to posting the focal call for bids. platform prior to posting the focal project description

Project Payment The buyer's initial Ostrom and payment offered for the Iacobucci service. (1995)

The actual dollar value offered by the buyer in her call for bids, multiplied by an undisclosed index for anonymity purposes.
} 


\begin{tabular}{|c|c|c|c|}
\hline Construct & Definition & $\begin{array}{l}\text { Representative } \\
\text { Articles }\end{array}$ & Operationalization \\
\hline $\begin{array}{l}\text { Payment not } \\
\text { Disclosed }\end{array}$ & $\begin{array}{l}\text { The buyer did not } \\
\text { disclose a payment offer } \\
\text { upfront }\end{array}$ & $\begin{array}{l}\text { Horton and } \\
\text { Johari (2018) }\end{array}$ & $\begin{array}{l}\text { Coded (1) if the buyer indicated a payment offer } \\
\text { upfront along with the call for bids (1), or not }(0) \text {. }\end{array}$ \\
\hline Project Duration & $\begin{array}{l}\text { The buyer's expected } \\
\text { project duration. }\end{array}$ & Horton (2019) & $\begin{array}{l}\text { An indicator for a project's duration that was } \\
\text { specified by the buyer in her project description at } \\
\text { t } 1 \text { to last either more (1) or less than a month }(0) \text {. }\end{array}$ \\
\hline $\begin{array}{l}\text { Excess Supply of } \\
\text { Freelancers }\end{array}$ & $\begin{array}{l}\text { The relative amount of } \\
\text { supply (in freelancers) to } \\
\text { the amount of projects } \\
\text { available in any given } \\
\text { sub-market }\end{array}$ & Horton (2019) & $\begin{array}{l}\text { Number of active freelancers (all freelancers in the } \\
\text { specific submarket, who will submit at least one } \\
\text { bid in the future), divided by the number of buyers } \\
\text { who post call for bids around the same time ( } \pm 31 \\
\text { days) and in the same submarket }\end{array}$ \\
\hline \multicolumn{4}{|c|}{ Additional Controls for Freelancers' Bid Success } \\
\hline $\begin{array}{l}\text { Linguistic style } \\
\text { matching (LSM) }\end{array}$ & $\begin{array}{l}\text { The extent to which two } \\
\text { texts match in function } \\
\text { word use }\end{array}$ & $\begin{array}{l}\text { Ludwig et al. } \\
\text { (2013) }\end{array}$ & $\begin{array}{l}\text { The degree of LSM across each function word } \\
\text { category in a freelancer's bid to a buyer's call for } \\
\text { bids. By aggregating all nine LSM scores with } \\
\text { equal weights, we obtain an LSM score bound } \\
\text { between } 0 \text { and } 1 \text {, and scores closer to } 1 \text { reflect } \\
\text { greater degree of communication style matching } \\
\text { between the freelancer and buyer. }\end{array}$ \\
\hline $\begin{array}{l}\text { Freelancer } \\
\text { Experience }\end{array}$ & $\begin{array}{l}\text { The number of projects } \\
\text { the freelancer already } \\
\text { completed }\end{array}$ & $\begin{array}{l}\text { Hong and } \\
\text { Pavlou (2017) }\end{array}$ & $\begin{array}{l}\text { The number of projects the freelancer already } \\
\text { completed prior to submitting her bid to the focal } \\
\text { call for bids. }\end{array}$ \\
\hline Freelancer Rating & $\begin{array}{l}\text { The average five-point } \\
\text { quality rating the } \\
\text { freelancer received from } \\
\text { all previous projects }\end{array}$ & $\begin{array}{l}\text { Hong and } \\
\text { Pavlou (2017) }\end{array}$ & $\begin{array}{l}\text { The average five-point quality rating the } \\
\text { freelancer received from all previous projects } \\
\text { (with } 5 \text { indicating highest quality). }\end{array}$ \\
\hline $\begin{array}{l}\text { Previous } \\
\text { relationship }\end{array}$ & $\begin{array}{l}\text { Whether the exchange } \\
\text { relation was a repeat- or a } \\
\text { first-time business } \\
\text { interactions }\end{array}$ & $\begin{array}{l}\text { Hong and } \\
\text { Pavlou (2017) }\end{array}$ & $\begin{array}{l}\text { Coded (1) if the freelancer had completed a } \\
\text { project with the specific buyer before and }(0) \text { if } \\
\text { not. }\end{array}$ \\
\hline Bid Price & $\begin{array}{l}\text { The relative asking price } \\
\text { by the freelancer }\end{array}$ & $\begin{array}{l}\text { Hong and } \\
\text { Pavlou (2017) }\end{array}$ & $\begin{array}{l}\text { The percentage by which the actual dollar value } \\
\text { asked for by the freelancer in her bid (multiplied } \\
\text { by an undisclosed index for anonymity purposes) } \\
\text { exceeds (or falls short of) the average asking price } \\
\text { of all competing bids for the same project. }\end{array}$ \\
\hline Time-to-bid & $\begin{array}{l}\text { Duration it took for the } \\
\text { freelancer to submit her } \\
\text { bid }\end{array}$ & $\begin{array}{l}\text { Dalya and Nath } \\
\text { (2005) }\end{array}$ & $\begin{array}{l}\text { Time in days it took the freelancer to submit her } \\
\text { bid (time-to-bid), following the call for bids }\end{array}$ \\
\hline Late submission & $\begin{array}{l}\text { Whether the bid was } \\
\text { submitted late }\end{array}$ & N.A. & $\begin{array}{l}\text { Whether the bid was submitted late (1) or on time } \\
(0) \text {. }\end{array}$ \\
\hline Competition & $\begin{array}{l}\text { How many freelancers } \\
\text { were applying for the } \\
\text { same call for bids }\end{array}$ & Horton (2019) & $\begin{array}{l}\text { The number of freelancers who applied for the } \\
\text { same call for bids. }\end{array}$ \\
\hline
\end{tabular}


WA p. 8

\section{WA\#D: Illustrative Figure of Freelancer Profile}

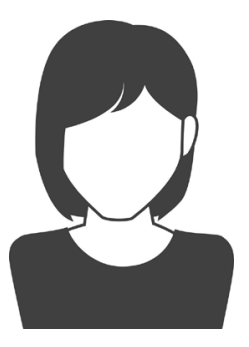

Name: Jennifer S.

Rating: 4.5 out of 5 stars

Number of Projects completed: 17

Skills: Keynote Microsoft PowerPoint Presentation Data Visualization

Infographics Copywriting 


\section{WA\#E: Response Surface Methodology}

Our measures of communication mimicry are based on the constraints placed within the polynomial model using the freelancer's and buyer's communication aspects. Earlier studies have examined communication mimicry using a difference score approach (e.g., Ludwig et al. 2013; Soliz and Giles 2014). However, given the conceptual and methodological problems it creates, Edwards and Parry (1993) recommend the polynomial technique as an effective alternative that can avoid the limitations of the difference score approach. An increasing number of studies have used the polynomial technique to explore such topics as perceptual differences and (mis)fit (e.g., Mullins et al. 2015; Menguc et al. 2016). For instance, by using polynomial regression with response surface analysis we are able to test predictions as to how bid success and service price premium may change when freelancers' of mimic different levels of buyers' task information. One of the benefits of polynomial regression is that the effect of mimicking on an outcome is treated as a three-dimensional surface, simultaneously relating the degree of mimicry as well as the freelancer's and buyer's communication levels to the respective outcomes (i.e., bid success and price premium). These graphs allow us to examine the precise nature of mimicry relationships (e.g., Harris, Anseel, and Lievens 2008) and study at which level of communication mimicry by the freelancer towards the buyer is beneficial or aversive.

In polynomial modeling, the dependent variable is estimated by entering five polynomial terms into the equation. For example, we estimated bid success against a freelancer's task information (FTASK), buyer's task information (BTASK), and the three higher-order effects (i.e., FTASK $^{2}$, FTASK $\times$ BTASK, and BTASK $^{2}$ ) that are created as product terms of FTASK and BTASK in Table 3, Model 4. We standardized all communication variables because means and standard deviations are comparable across freelances and buyers (Shanock et al. 2010). Yet 
the estimated coefficients that relate to the effect of each polynomial term on bid success individually are not directly employed to test any proposition. Rather, the estimated coefficient for each polynomial term is used to compute the slope and curvature along the fit and misfit lines, which is also known as response surface analysis. Using Edwards and Parry’s (1993) formula, we computed the slopes and curvatures along the fit (FTASK $=$ BTASK) and misfit $\left(\right.$ FTASK $=$ - BTASK) lines as fit slope $($ FTASK + BTASK I $)$ and fit curvature $\left(\right.$ FTASK $^{2}+$ FTASK $\times$ BTASK + BTASK $^{2}$ ) and misfit slope (FTASK - BTASK) and misfit curvature $\left(\right.$ FTASK $^{2}-$ FTASK $\times$ BTASK + BTASK $\left.^{2}\right)$. Because of the nested nature of our data (i.e., multiple bids from each freelancer), we took a multilevel, random coefficients approach to the polynomial modeling technique (e.g., Jansen and Kristof-Brown 2005). As a result, we employed multilevel path analysis to estimate the model's proposed relationships simultaneously. Thus, the relationship between freelancer's task information, buyer's task information, and bid success in Table 3, Model 4 can be written as:

$$
\begin{aligned}
\text { BIDSUC }_{k l}= & y_{00}+y_{01} \text { FTASK }_{k l}+y_{05} \text { BTASK }_{k l}+y_{09} F_{T A S K} S Q_{k l} \\
& +y_{13}\left(F_{T A S K_{k l}} \times \text { BTASK }_{k l}\right)+y_{17} \text { BTASK_S } Q_{k l}+\mu_{0 l}+\varepsilon_{k l}
\end{aligned}
$$

where $B I D S U C_{k l}$ is the success of bid $\mathrm{k}$ from freelancer $\mathrm{l}, F T A S K_{k l}$ is freelancer task information, $B T A S K_{k l}$ is buyer task information, $F T A S K_{-} S Q_{k l}$ is freelancer task information squared, $\left(F T A S K_{k l} \times B T A S K_{k l}\right)$ is the interaction term between freelancer and buyer task information, BTASK_S $Q_{k l}$ is buyer task information squared, $\mu_{0 l}$ is the random intercept, and $\varepsilon_{k l}$ is the error term. We stated that mimicking buyers' task information should increase freelancers' bid success. To test whether bid success varies for misfit in task information, we define the polynomial regression with FTASK = - BTASK. Substituting FTASK = - BTASK in equation WA1, the misfit line can be written as: 
(WA2)

$$
\begin{aligned}
\text { BIDSUC }_{k l}= & y_{00}+\left(y_{01}-y_{05}\right) \text { FTASK }_{k l}+\left(y_{09}-y_{13}\right. \\
& \left.+y_{17}\right) \text { FTASK_SQq } q_{k l}+\mu_{0 l}+\varepsilon_{k l},
\end{aligned}
$$

where the misfit line slope $\left(y_{01}-y_{05}\right)$ represents the linear effect of freelancer task information that are greater than buyer task information. When the effect is positive, bid success increases as freelancer task information grows greater than buyer task information, but decreases as freelancer task information decreases further below buyer task information. The misfit line curvature $\left(y_{09}-y_{13}+y_{17}\right)$ represents the non-linear effect of misfit in task information on bid success. When this effect is positive (i.e., u-shaped), bid success will be at a minimum at perfect fit and increase with misfit when freelancer task information either under- or overestimates buyer task information. Conversely, when the effect is negative (i.e., inverted u-shaped), bid success will be maximized at perfect fit, and decrease as freelancer task information either under- or overestimates buyer task information.

We further qualified this effect and proposed that when freelancers mimic buyers' who provide little task information, their chance of bid success decrease. Thus, in this situation it would be beneficial for the freelancer to provide more task information regardless of the buyer. To test this, we inspect the slope of FTASK when BTASK is at -1.5 standard deviations below the mean:

$$
\begin{aligned}
\text { BIDSUC }_{k l}= & y_{00}+y_{01} \text { FTASK }_{k l} \\
& -\left(1.5 S D \times y_{13}\left(F T A S K_{k l} \times \text { BTASK }_{k l}\right)\right)+\mu_{0 l}+\varepsilon_{k l},
\end{aligned}
$$

where a positive effect would indicate that providing more task information is better for the freelancer. Summarizing the explanations above, assessing the response surface allows a novel and quantitative description of the three-dimensional relationships between freelancer's task information, buyer's task information, and bid success (as well as price premium). 
WA p. 12

\section{WA\#F: Manual Validity Checks of Text Analysis Approach}

To ensure the validity of the text analysis, two expert coders were used to classify the texts of a random subsample of 100 call for bids (with a mean of 129 words) and 100 bids (with a subsample mean of 125 words). For each text the coders indicated whether they agreed (coded 1) that "The buyer/freelancer presents a lot of information related to the service task" (adapted from Venkatesh, Kohli, and Zaltman 1995). "The buyer/freelancer writes about her/himself for fairly long period” (Wheeless 1976), “The buyer's call for bids/ freelancer's bid text is extremely concrete” (Krishnan, Biswas, and Netemeyer 2006), “The buyer's call for bids/ freelancer's bid text feels very emotional (Hamilton and Stewart 1993)

After practicing on five example call-for bids and bids, the coders classified the sampled texts, and we compared their classification with the automated text analysis. Between the coders and the automated text analysis, generally substantial agreement levels were achieved $(.71<\mathrm{a}<$ .87 for the call for bids and $.82<\mathrm{a}<.92$, for the bids; Krippendorff 2013). Following our automatic text mining approach, we classified those bids that contained above average degrees of (1) task information, (2) personal information, (3) concreteness and (4) affective intensity as (1) and below average degrees as (0). Averages for call for bids and bids are shown in Web Appendix J. In those cases where the coders agreed, on average, substantial agreement levels were achieved between the agreed coder classification and the classification using the automated text analysis $(.73<\mathrm{a}<.94$ for the call for bids and $.66<\mathrm{a}<.88$, for the bids; Krippendorff 2013).

Following Berger et al. (2020) we then calculated precision, recall, and the F1-Measure (see Table WA E1). Overall our results demonstrate the accuracy of our text mined measures. 
Table WA F1. Krippendorff's Alpha, Precision, Recall, and F-Measure

\begin{tabular}{|c|c|c|c|c|c|}
\hline Text-Mined Measures & $\begin{array}{c}\text { Krippendorff's } \boldsymbol{\alpha} \\
\text { between coders } \\
\text { (bids / calls for bids) }\end{array}$ & $\begin{array}{c}\text { Krippendorff's } \alpha \\
\text { between coders and } \\
\text { automated measurement } \\
\text { (bids / calls for bids) }\end{array}$ & $\begin{array}{c}\text { Precision } \\
\text { (bids / calls for bids) }\end{array}$ & $\begin{array}{l}\text { Recall } \\
\text { (bids / calls for bids) }\end{array}$ & $\begin{array}{c}\text { F-Measure } \\
\text { (bids / calls for bids) }\end{array}$ \\
\hline \multicolumn{6}{|l|}{ Communication Content } \\
\hline Task Information & $.86 / .83$ & $.86 / .85$ & $.89 / .87$ & $.93 / .93$ & $.91 / .90$ \\
\hline Personal Information & $.92 / .87$ & $.88 / .94$ & $1.00 / .91$ & $.89 / 1.00$ & $.95 / .95$ \\
\hline \multicolumn{6}{|l|}{ Communication Style } \\
\hline Concreteness & $.82 / .87$ & $.66 / .73$ & $1.00 / .67$ & $.66 / 1.00$ & $.79 / .80$ \\
\hline Affective Intensity & $.89 / .71$ & $.88 / .88$ & $.96 / 1.00$ & $.89 / .80$ & $.92 / .89$ \\
\hline Mean & $.88 / .82$ & $.82 / .85$ & $.96 / .86$ & $.84 / .93$ & $.89 / .89$ \\
\hline
\end{tabular}

Note. Precision (true positives / (true positives + false positives)) is the count of correct class predictions by the text mining approach that actually belong to the positive class (correct was what the human coders agreed on), recall (true positives / (true positives + false negatives)) quantifies the number of positive class predictions made by the text mining approach out of all positive classifications made by the human coders, and the F1-Measure is the harmonic mean of the levels of recall and precision $(2 *$ Precision * Recall) / (Precision + Recall). 
WA p. 14

Table W F2. Human Coder Correlations for Bids

\begin{tabular}{|c|c|c|c|c|c|c|c|c|c|c|c|c|}
\hline & 1 & 2 & 3 & 4 & 5 & 6 & 7 & 8 & 9 & 10 & 11 & 12 \\
\hline \multicolumn{13}{|l|}{ 1. Task information Coder 1} \\
\hline 2. Task information Coder 2 & .82 & & & & & & & & & & & \\
\hline 3. Task information PC & .82 & .73 & & & & & & & & & & \\
\hline 4. Personal information Coder 1 & -.12 & -.17 & -.10 & & & & & & & & & \\
\hline 5. Personal information Coder 2 & -.13 & -.13 & -.11 & .87 & & & & & & & & \\
\hline 6. Personal information PC & -.05 & -.10 & -.03 & .92 & .84 & & & & & & & \\
\hline 7. Concreteness Coder 1 & .12 & .03 & .06 & -.07 & -.18 & -.10 & & & & & & \\
\hline 8. Concreteness Coder 2 & .14 & .05 & .13 & -.12 & -.19 & -.16 & .87 & & & & & \\
\hline 9. Concreteness PC & .15 & .10 & .12 & -.08 & -.15 & -.07 & .75 & .66 & & & & \\
\hline 10. Affective intensity Coder 1 & -.17 & -.07 & -.16 & .19 & .19 & .20 & -.07 & -.15 & -.02 & & & \\
\hline 11. Affective intensity Coder 2 & -.01 & -.01 & .00 & .25 & .24 & .26 & -.10 & -.17 & -.04 & .72 & & \\
\hline 12. Affective intensity PC & -.17 & -.17 & -.16 & .30 & .29 & .31 & -.07 & -.15 & -.02 & .79 & .72 & \\
\hline
\end{tabular}

Note. $\mathrm{N}=100$. Coder 1 and 2 refers to the two human coders for this validation study and "PC" is the classification by the text mining approach.

Table F3. Human Coder Correlations for Calls for Bids

\begin{tabular}{|c|c|c|c|c|c|c|c|c|c|c|c|c|}
\hline & 1 & 2 & 3 & 4 & 5 & 6 & 7 & 8 & 9 & 10 & 11 & 12 \\
\hline 1. Task information Coder 1 & & & & & & & & & & & & \\
\hline 2. Task information Coder 2 & .86 & & & & & & & & & & & \\
\hline 3. Task information PC & .86 & .77 & & & & & & & & & & \\
\hline 4. Personal information Coder 1 & -.18 & -.13 & -.14 & & & & & & & & & \\
\hline 5. Personal information Coder 2 & -.16 & -.16 & -.17 & .92 & & & & & & & & \\
\hline 6. Personal information PC & -.17 & -.13 & -.13 & .89 & .84 & & & & & & & \\
\hline 7. Concreteness Coder 1 & .10 & .14 & .08 & -.42 & -.45 & -.45 & & & & & & \\
\hline 8. Concreteness Coder 2 & .17 & .22 & .16 & -.48 & -.47 & -.57 & .82 & & & & & \\
\hline 9. Concreteness PC & .14 & .18 & .10 & -.37 & -.37 & -.40 & .64 & .63 & & & & \\
\hline 10. Affective intensity Coder 1 & -.22 & -.18 & -.20 & .10 & .12 & .16 & -.16 & -.16 & -.11 & & & \\
\hline 11. Affective intensity Coder 2 & -.20 & -.20 & -.18 & .14 & .16 & .16 & -.19 & -.18 & -.12 & .90 & & \\
\hline 12. Affective intensity PC & -.24 & -.14 & -.21 & .08 & .09 & .13 & -.13 & -.13 & -.13 & .88 & .82 & \\
\hline
\end{tabular}

Note. $\mathrm{N}=100$. Coder 1 and 2 refers to the two human coders for this validation study and "PC" is the classification by the text mining approach. 


\section{WA\#G: Experimental Evidence of Uncertainty Reduction}

We use single-factor, within-subject designs for each of the four communication aspects. Across the studies, between 50 and 53 U.S. consumers, with a mean age of 37.6 years $(50 \%$ women), were recruited from Amazon Mechanical Turk. Confidentiality was assured, and participants were told to imagine hiring someone to write content for their website on Upwork (a global freelancing website). To qualify to participate, respondents had to be native English speakers and sufficient online freelance marketplace experience (i.e., a minimum of 1,000 submitted task on MTurk). Moreover, on a scale from 1 = "do not agree" to 7 = "fully agree", they scored on average 5.89 regarding the statement "I have experience working as a freelancer on online platforms". An instructional manipulation check excluded two to four participants from each study. Following the introduction, participants were randomly allocated to one of four communication aspects (i.e., task information, personal information, concreteness, and affective intensity), then exposed in random order to two different bids from two different freelancers, using strategies that reflected the greater or lesser degree version of the focal condition, such that it was at least one standard deviation different from the value obtained in the field study (e.g., for example the mean difference of personal information between our high- and low condition is $4.32 \%,(2.50 \%$ vs. $6.82 \%)$ as determined using our text mining approach. We provide an example of the stimuli in Figure G1; the text for all stimuli is in Table G2.

After reading the stimuli, participants indicated their hiring intentions for each bid and chose one of the two bids, using a seven-point semantic differential scale $(1=$ "definitely bid A" to 4 = "indifferent" to 7 = "definitely bid B"), where bid A and bid B feature the greater and lesser use of the respective communication aspect, assigned randomly. Next, we asked participants to rate each bid according to the level of uncertainty related to the freelancer who 
WA p. 16

submitted the bid with a measure from Grewal, Gotlieb, and Marmorstein 1994; "How confident are you that the freelancer will perform well?", "How certain are you that the freelancer will work satisfactory?", "Do you feel that the freelancer will perform as requested?”, $\alpha=.93$ ). We used the questions from the manual validity check reported in Web Appendix F as manipulation checks. Table G3 provides all means and standard deviations.

All the text manipulations were successful, and the simple contrasts and participants' choices are in line with our expectations (see Table G4). They indicated greater hiring intentions for bids that contained more task information $\left(\mathrm{M}_{\text {high }}=5.44, \mathrm{M}_{\mathrm{low}}=4.28 t(51)=3.84, p<.01\right)$, more personal information $\left(\mathrm{M}_{\mathrm{high}}=5.28, \mathrm{M}_{\mathrm{low}}=4.00 ; t(49)=6.96, p<.01\right)$, more concreteness $\left(\mathrm{M}_{\text {high }}=5.23, \mathrm{M}_{\text {low }}=4.06 ; t(52)=4.11, p<.01\right)$, and more affective intensity $\left(\mathrm{M}_{\text {high }}=5.55, \mathrm{M}_{\text {low }}\right.$ $=4.49 ; t(50)=3.58, p<.01)$. We then applied mediation procedures to the within-subjects designs (Montoya and Hayes 2017) and the MEMORE macro to test for the mediating role of uncertainty reduction between the communication strategies and hiring intentions. The greater versus lesser use of each communication aspect in each study predicts uncertainty reduction ( $\beta \mathrm{s}$ between .76 and 1.35, all $p<.01)$. In turn, uncertainty reduction significantly predicts hiring intention ( $\beta$ s between .84 and 1.21, all $p<.01$ ), and 5,000 bootstrap samples reveal indirect effects of greater versus lesser uses of each communication aspect on hiring intentions, through uncertainty reduction ( $\beta$ s between .82 and 1.32 , all $95 \%$ confidence intervals range from .43 to $1.83)$. 
2

Figure WA G1. Sample Stimuli

\section{Study Context}

Imagine you want to hire someone to write content for your website. Thus, you visit Upwork — the largest global freelancing website to hire a freelancer. In the following, you will read two different bids from two different freelancers. We will ask you to rate each bid and to choose one of the two bids.

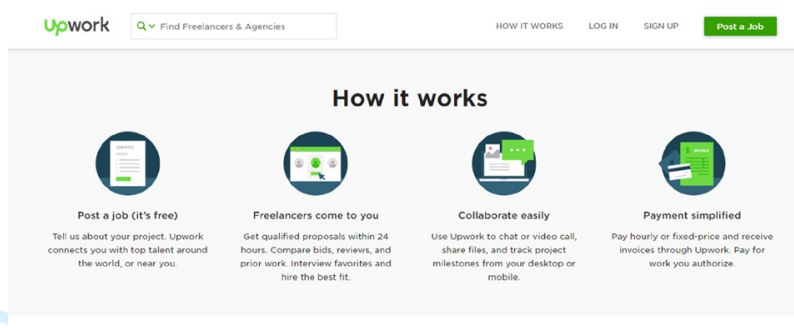

Sign up for free project quotes

\section{Low Task Information Bid}

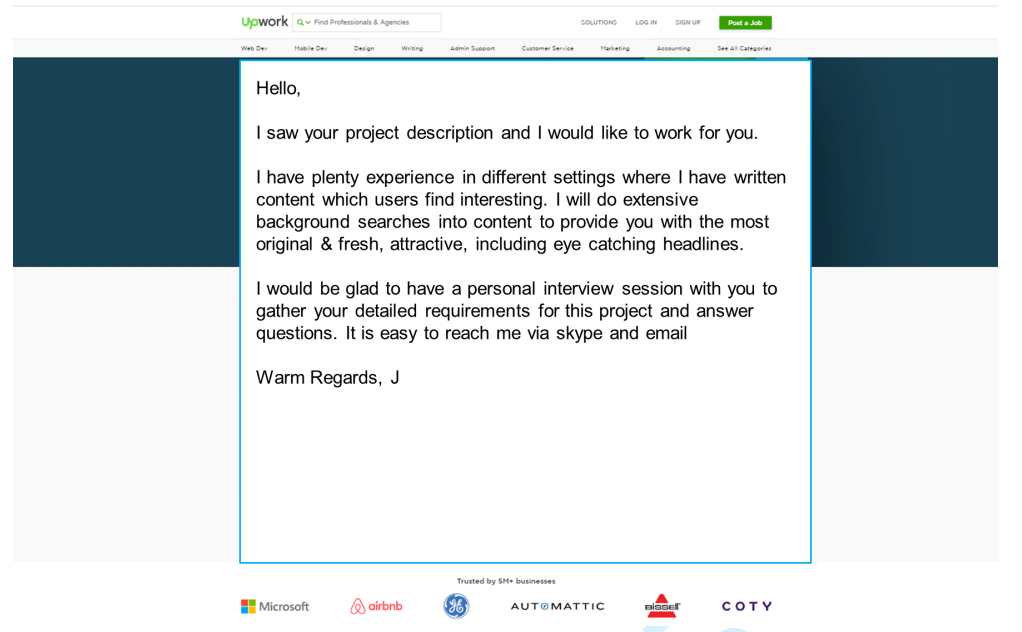

High Task Information Bid

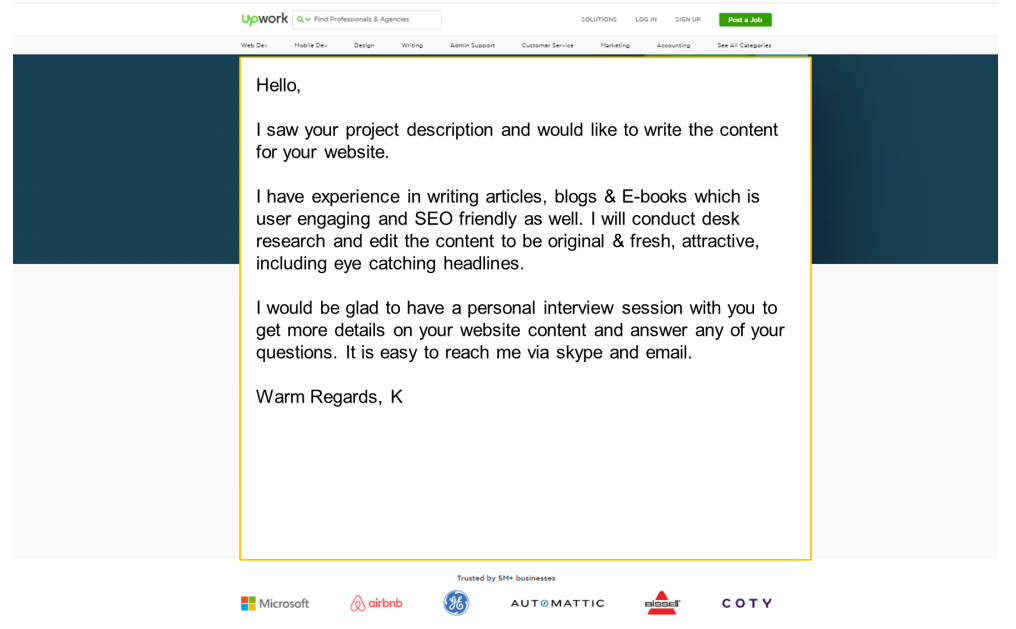

Note: We randomized the order of the bids in all experimental studies. 
Table WA G2. Text for All Stimuli

\begin{tabular}{|c|c|c|c|c|}
\hline & A: Task Information & D: Personal Information & C: Concreteness & D: Affective Intensity \\
\hline $\begin{array}{l}\text { Low Bid } \\
\text { Condition }\end{array}$ & $\begin{array}{l}\text { I saw your project description and I } \\
\text { would like to work for you. I have } \\
\text { plenty experience in different settings } \\
\text { where I have written content which } \\
\text { users find interesting. I will do } \\
\text { extensive background searches into } \\
\text { content to provide you with the most } \\
\text { original \& fresh, attractive, including } \\
\text { eye catching headlines. I would be } \\
\text { glad to have a personal interview } \\
\text { session with you to gather your } \\
\text { detailed requirements for this project } \\
\text { and answer questions. It is easy to } \\
\text { reach me via skype and email }\end{array}$ & $\begin{array}{l}\text { Saw your project description and } \\
\text { would like to write the content for } \\
\text { your site. Have experience in } \\
\text { writing articles, blogs \& E-books } \\
\text { which is user engaging and SEO } \\
\text { friendly as well. Content provided } \\
\text { by me will be original \& fresh, } \\
\text { attractive, including eye catching } \\
\text { headlines, fully researched and } \\
\text { relevant. Would be glad to have a } \\
\text { personal interview session with } \\
\text { you to gather your detailed } \\
\text { requirements and answer any of } \\
\text { your questions. It is easy to reach } \\
\text { me via skype and email. }\end{array}$ & $\begin{array}{l}\text { I noticed your project description } \\
\text { and I would like to do work on it. I } \\
\text { have plenty of experience in } \\
\text { scripting text, which is engaging, } \\
\text { compelling, and SEO friendly. I can } \\
\text { write ideal content and optimize your } \\
\text { existing ones. Content provided by } \\
\text { me will be spiriting, attractive, with } \\
\text { striking headlines, researched and } \\
\text { relevant. I would be glad to have a } \\
\text { personal interview with you to gather } \\
\text { requirements and answer queries. It } \\
\text { is easy to get in touch with me via } \\
\text { various communication channels. }\end{array}$ & $\begin{array}{l}\text { I saw your project description } \\
\text { and I can write the required } \\
\text { content for your site. I have } \\
\text { plenty of experience in writing } \\
\text { articles, blogs \& E-books which } \\
\text { is user engaging and SEO } \\
\text { friendly as well. Content } \\
\text { provided by me will be original, } \\
\text { including eye catching headlines, } \\
\text { fully researched and relevant. Let } \\
\text { us have a personal interview } \\
\text { session to gather your detailed } \\
\text { requirements and answer any } \\
\text { questions. Reach me via skype } \\
\text { and email. }\end{array}$ \\
\hline $\begin{array}{l}\text { High Bid } \\
\text { Condition }\end{array}$ & $\begin{array}{l}\text { I saw your project description and } \\
\text { would like to write the content for } \\
\text { your website. I have experience in } \\
\text { writing articles, blogs \& E-books } \\
\text { which is user engaging and SEO } \\
\text { friendly as well. I will conduct desk } \\
\text { research and edit the content to be } \\
\text { original \& fresh, attractive, including } \\
\text { eye catching headlines. I would be } \\
\text { glad to have a personal interview } \\
\text { session with you to get more details } \\
\text { on your website content and answer } \\
\text { any of your questions. It is easy to } \\
\text { reach me via skype and email. }\end{array}$ & $\begin{array}{l}\text { I saw your project description and } \\
\text { would like to write the content for } \\
\text { your site. I have } 12 \text { years of work } \\
\text { experience in copy writing for } \\
\text { articles, blogs \& E-books. I focus } \\
\text { on SEO friendly content as well. I } \\
\text { have a Master's in Journalism from } \\
\text { the University of Melbourne and } \\
\text { have worked fulltime for } \\
\text { companies like Adobe. I would be } \\
\text { glad to have a call with you to } \\
\text { gather your detailed requirements } \\
\text { and answer any of your questions. } \\
\text { It is easy to reach me via skype and } \\
\text { email. }\end{array}$ & $\begin{array}{l}\text { I saw your posted project description } \\
\text { on Upwork, and I would like to write } \\
\text { the contents for your website. I have } \\
\text { a lot of experience in article and } \\
\text { weblog writing in an SEO friendly } \\
\text { fashion. I can provide a lot of new } \\
\text { content and optimize the all the } \\
\text { current content on your site. The } \\
\text { content I add to your site will invite, } \\
\text { be crisp and flash headlines. If you } \\
\text { like we can have a kick off call to } \\
\text { answer any question you have? It is } \\
\text { easy to reach me via skype and } \\
\text { email. }\end{array}$ & $\begin{array}{l}\text { I liked your project description } \\
\text { and would be happy to write the } \\
\text { content for your site. I have great } \\
\text { experience in writing articles, } \\
\text { blogs \& E-books which is user } \\
\text { engaging and SEO friendly as } \\
\text { well. Content provided by me } \\
\text { will be original \& fresh, } \\
\text { attractive, including eye catching } \\
\text { headlines, fully researched and } \\
\text { relevant. I would be delighted to } \\
\text { have a kick off call and answer } \\
\text { any questions. It is easy to reach } \\
\text { me via skype and email. }\end{array}$ \\
\hline $\begin{array}{l}\text { Text } \\
\text { Mining } \\
\text { Results }\end{array}$ & $\begin{array}{l}\text { Task information: } \mathrm{M}_{\mathrm{low}}=19.28 \% \text { vs. } \\
\mathrm{M}_{\text {high }}=25.29 \%\end{array}$ & $\begin{array}{l}\text { Personal information: } \mathrm{M}_{\mathrm{low}}=2.50 \% \\
\text { vs. } \mathrm{M}_{\text {high }}=6.82 \%\end{array}$ & $\begin{array}{l}\text { Concreteness: } \mathrm{M}_{\mathrm{low}}=22.10 \% \text { vs. } \\
\mathrm{M}_{\mathrm{high}}=43.33 \%\end{array}$ & $\begin{array}{l}\text { Affective intensity: } \mathrm{M}_{\mathrm{low}}=6.94 \% \\
\text { vs. } \mathrm{M}_{\text {high }}=11.84 \%\end{array}$ \\
\hline
\end{tabular}


Table WA G3. Means and Standard Deviations

\begin{tabular}{|c|c|c|c|c|c|}
\hline \multicolumn{6}{|l|}{ A: Task Information } \\
\hline & \multicolumn{2}{|c|}{ Low Task Information } & \multicolumn{2}{|c|}{ High Task Information } & \multirow[b]{2}{*}{ Effect Size } \\
\hline & Mean & $\mathrm{SD}$ & Mean & $\mathrm{SD}$ & \\
\hline MC: Task Information & 4.28 & 1.57 & 5.33 & 1.27 & .52 \\
\hline Mediator: Risk Reduction & 4.59 & 1.47 & 5.43 & 1.28 & .43 \\
\hline DV: Hiring Intention & 4.35 & 1.63 & 5.44 & 1.21 & .54 \\
\hline \multicolumn{6}{|l|}{ B: Personal Information } \\
\hline & \multicolumn{2}{|c|}{ Low Personal Information } & \multicolumn{2}{|c|}{ High Personal Information } & \\
\hline & Mean & $\mathrm{SD}$ & Mean & $\mathrm{SD}$ & Effect Size \\
\hline MC: Personal Information & 4.78 & 1.13 & 5.73 & .95 & .64 \\
\hline Mediator: Risk Reduction & 4.33 & 1.53 & 5.67 & 1.15 & .70 \\
\hline DV: Hiring Intention & 4.00 & 1.46 & 5.82 & 1.26 & .95 \\
\hline \multicolumn{6}{|l|}{ C: Concreteness } \\
\hline & \multicolumn{2}{|c|}{ Low Concreteness } & \multicolumn{2}{|c|}{ High Concreteness } & \\
\hline & Mean & $\mathrm{SD}$ & Mean & $\mathrm{SD}$ & Effect Size \\
\hline MC: Concreteness & 4.50 & 1.30 & 5.50 & 1.28 & .54 \\
\hline Mediator: Risk Reduction & 4.57 & 1.27 & 5.30 & 1.47 & .38 \\
\hline DV: Hiring Intention & 4.06 & 1.51 & 5.23 & 1.58 & .54 \\
\hline \multicolumn{6}{|l|}{ D: Affective Intensity } \\
\hline & \multicolumn{2}{|c|}{ Low Affective Intensity } & \multicolumn{2}{|c|}{ High Affective Intensity } & \\
\hline & Mean & $\mathrm{SD}$ & Mean & SD & Effect Size \\
\hline MC: Affective Intensity & 5.08 & 1.14 & 5.96 & .90 & .61 \\
\hline Mediator: Risk Reduction & 4.74 & 1.26 & 5.50 & 1.17 & .44 \\
\hline DV: Hiring Intention & 4.49 & 1.47 & 5.55 & 1.29 & .54 \\
\hline
\end{tabular}

Note: $\mathrm{MC}=$ Manipulation Check, DV $=$ Dependent Variable. 


\section{Table WA G4. Results in the Pilot Studies}

\begin{tabular}{|c|c|c|c|c|}
\hline & A: Task Information & B: Personal Information & C: Concreteness & D: Affective Intensity \\
\hline Participants & $\begin{array}{l}52 \text { U.S. consumers, mean age } 38.4 \\
\text { years, } 38 \% \text { women (the } \\
\text { instructional manipulation check } \\
\text { excluded four participants) }\end{array}$ & $\begin{array}{l}50 \text { U.S. consumers, mean age } 41.9 \\
\text { years, } 49 \% \text { women (the } \\
\text { instructional manipulation check } \\
\text { excluded two participants) }\end{array}$ & $\begin{array}{l}53 \text { U.S. consumers, mean age } 36.7 \\
\text { years, } 43 \% \text { women (the } \\
\text { instructional manipulation check } \\
\text { excluded three participants) }\end{array}$ & $\begin{array}{l}51 \text { U.S. consumers, mean age } 40.4 \\
\text { years, } 47 \% \text { women (the } \\
\text { instructional manipulation check } \\
\text { excluded four participants) }\end{array}$ \\
\hline $\begin{array}{l}\text { Manipulation } \\
\text { measure }\end{array}$ & $\begin{array}{l}\text { Amount of task information } \\
\text { (Sicilia and Ruiz 2010) }\end{array}$ & $\begin{array}{l}\text { Self-disclosure scale (Wheeless } \\
\text { 1976) }\end{array}$ & $\begin{array}{l}\text { Level of concreteness (Krishnan, } \\
\text { Biswas, and Netemeyer 2006) }\end{array}$ & $\begin{array}{l}\text { Valence of information exchanged } \\
\text { (Adjei, Noble, and Noble 2010) }\end{array}$ \\
\hline $\begin{array}{l}\text { Manipulation } \\
\text { check }\end{array}$ & $\begin{array}{l}\text { Manipulated successfully }\left(\mathrm{M}_{\text {high }}\right. \\
=5.33, \mathrm{M}_{\text {low }}=4.28 ; t(51)=3.84, p \\
<.01)\end{array}$ & $\begin{array}{l}\text { Manipulated successfully }\left(\mathrm{M}_{\mathrm{high}}\right. \\
=5.73, \mathrm{M}_{\mathrm{low}}=4.78 ; t(49)=5.24, p \\
<.01)\end{array}$ & $\begin{array}{l}\text { Manipulated successfully }\left(\mathrm{M}_{\text {high }}\right. \\
=5.50, \mathrm{M}_{\text {low }}=4.50 ; t(52)=4.71, p \\
<.01)\end{array}$ & $\begin{array}{l}\text { Manipulated successfully }\left(\mathrm{M}_{\mathrm{high}}\right. \\
=5.96, \mathrm{M}_{\mathrm{low}}=5.08 ; t(50)=4.54, p \\
<.01)\end{array}$ \\
\hline $\begin{array}{l}\text { Paired sample } \\
\text { results }\end{array}$ & $\begin{array}{l}\text { High vs. low task information } \\
\text { significantly predicts hiring } \\
\text { intention }\left(\mathrm{M}_{\mathrm{high}}=5.44, \mathrm{M}_{\text {low }}=\right. \\
4.35 ; t(51)=4.03, p<.01)\end{array}$ & $\begin{array}{l}\text { High vs. low personal information } \\
\text { significantly predicts hiring } \\
\text { intention }\left(\mathrm{M}_{\text {high }}=5.28, \mathrm{M}_{\text {low }}=\right. \\
4.00 ; t(49)=6.96, p<.01)\end{array}$ & $\begin{array}{l}\text { High vs. low concreteness } \\
\text { significantly predicts hiring } \\
\text { intention }\left(\mathrm{M}_{\mathrm{high}}=5.23, \mathrm{M}_{\text {low }}=\right. \\
4.06 ; t(52)=4.11, p<.01)\end{array}$ & $\begin{array}{l}\text { High vs. low affective intensity } \\
\text { significantly predicts hiring } \\
\text { intention }\left(\mathrm{M}_{\mathrm{high}}=5.55, \mathrm{M}_{\text {low }}=\right. \\
4.49 ; t(50)=3.58, p<.01)\end{array}$ \\
\hline $\begin{array}{l}\text { Open choice } \\
\text { results }\end{array}$ & $\begin{array}{l}81 \% \text { choose the high task } \\
\text { information amount bid }\end{array}$ & $\begin{array}{l}90 \% \text { choose the high personal } \\
\text { information bid }\end{array}$ & $\begin{array}{l}68 \% \text { choose the high concreteness } \\
\text { bid }\end{array}$ & $75 \%$ choose the high intensity bid \\
\hline \multirow[t]{3}{*}{$\begin{array}{l}\text { Mediation } \\
\text { results }\end{array}$} & $\begin{array}{l}\text { - High vs. low task information } \\
\text { significantly predicts risk } \\
\text { reduction }(\beta=1.09, p<.01)\end{array}$ & $\begin{array}{l}\text { - High vs. low personal } \\
\text { information significantly predicts } \\
\text { risk reduction }(\beta=1.35, p<.01)\end{array}$ & $\begin{array}{l}- \text { High vs. low concreteness } \\
\text { significantly predicts risk } \\
\text { reduction }(\beta=.93, p<.01)\end{array}$ & $\begin{array}{l}\text { - High vs. low affective intensity } \\
\text { significantly predicts risk } \\
\text { reduction }(\beta=.76, p<.01)\end{array}$ \\
\hline & $\begin{array}{l}\text { - Risk reduction significantly } \\
\text { predicts hiring intention }(\beta=.84 \text {, } \\
p<.01)\end{array}$ & $\begin{array}{l}\text { - } \text { Risk reduction significantly } \\
\text { predicts hiring intention }(\beta=.98 \\
p<.01)\end{array}$ & $\begin{array}{l}\text { - Risk reduction significantly } \\
\text { predicts hiring intention }(\beta=.92 \\
p<.01)\end{array}$ & $\begin{array}{l}\text { - Risk reduction significantly } \\
\text { predicts hiring intention }(\beta= \\
1.21, p<.01)\end{array}$ \\
\hline & $\begin{array}{l}\text { - There is an indirect effect of high } \\
\text { vs. low task information on } \\
\text { hiring intention through risk } \\
\text { reduction }(\beta=.82,95 \% \text { CI } .43 \text { to } \\
1.25) \text {. }\end{array}$ & $\begin{array}{l}\text { - There is an indirect effect of high } \\
\text { vs. low personal information on } \\
\text { hiring intention through risk } \\
\text { reduction }(\beta=1.32,95 \% \text { CI } .89 \\
\text { to } 1.83) \text {. }\end{array}$ & $\begin{array}{l}- \text { There is an indirect effect of high } \\
\text { vs. low concreteness on hiring } \\
\text { intention through risk reduction } \\
(\beta=.85,95 \% \text { CI } .37 \text { to } 1.52) \text {. }\end{array}$ & $\begin{array}{l}\text { - There is an indirect effect of high } \\
\text { vs. low affective intensity on } \\
\text { hiring intention through risk } \\
\text { reduction }(\beta=.91,95 \% \text { CI } .42 \text { to } \\
1.40) \text {. }\end{array}$ \\
\hline
\end{tabular}

Note: $\mathrm{CI}=$ confidence interval. 


\section{WA\#H: Model Free Evidence}

Table H1. Model Free Evidence for Call for Bids' Success and Use of Communication Elements

\begin{tabular}{|c|c|c|c|c|c|c|c|c|}
\hline \multirow[b]{2}{*}{ Number of Bids } & \multicolumn{2}{|c|}{ Task Information } & \multicolumn{2}{|c|}{ Personal Information } & \multicolumn{2}{|c|}{ Concreteness } & \multicolumn{2}{|c|}{ Affective Intensity } \\
\hline & $\leq 5$ & $>5$ & $\leq 5$ & $>5$ & $\leq 5$ & $>5$ & $\leq 5$ & $>5$ \\
\hline Mean & .256 & .278 & .033 & .028 & .197 & .227 & .046 & .036 \\
\hline SD & .076 & .083 & .029 & .033 & .073 & .062 & .030 & .027 \\
\hline t-test & \multicolumn{2}{|c|}{-108.59} & \multicolumn{2}{|c|}{63.47} & \multicolumn{2}{|c|}{262.50} & \multicolumn{2}{|c|}{134.42} \\
\hline P-value & \multicolumn{2}{|c|}{$\mathrm{p}<.001$} & \multicolumn{2}{|c|}{$\mathrm{p}<.001$} & \multicolumn{2}{|c|}{$\mathrm{p}<.001$} & \multicolumn{2}{|c|}{$\mathrm{p}<.001$} \\
\hline
\end{tabular}

Note: We chose a cut off of 5 bids submitted, which is the mean number of bids submitted to call-for-bids across all 644.397 call for bids ( 403,262 call for bids received 5 bids or less; 241,135 call for bids received more than 5 bids).

\section{Table H2. Model Free Evidence for Bids' Success and Use of Communication Elements}

\begin{tabular}{|c|c|c|c|c|c|c|c|c|}
\hline \multirow[b]{2}{*}{ Bid Outcome } & \multicolumn{2}{|c|}{ Task Information } & \multicolumn{2}{|c|}{ Personal Information } & \multicolumn{2}{|c|}{ Concreteness } & \multicolumn{2}{|c|}{ Affective Intensity } \\
\hline & Lost & Won & Lost & Won & Lost & Won & Lost & Won \\
\hline Mean & .281 & .302 & .050 & .047 & .170 & .184 & .045 & .047 \\
\hline $\mathrm{SD}$ & .202 & .204 & .044 & .056 & .094 & .097 & .051 & .075 \\
\hline t-test & \multicolumn{2}{|c|}{-66.88} & \multicolumn{2}{|c|}{42.75} & \multicolumn{2}{|c|}{-95.61} & \multicolumn{2}{|c|}{-24.08} \\
\hline $\mathrm{P}$-value & \multicolumn{2}{|c|}{$\mathrm{p}<.001$} & \multicolumn{2}{|c|}{$\mathrm{p}<.001$} & \multicolumn{2}{|c|}{$\mathrm{p}<.001$} & \multicolumn{2}{|c|}{$\mathrm{p}<.001$} \\
\hline
\end{tabular}

Note: We split bids between those who won and those that lost across all 5,167,787 bids $(4,712,990$ bids were unsuccessful; 454,797 bids were successful).

Table H3. Model Free Evidence for Bids' Success and Mimicry of Communication Elements

\begin{tabular}{|c|c|c|c|c|c|c|c|c|c|c|c|c|}
\hline \multirow[b]{2}{*}{$\begin{array}{l}\text { Buyer's use of } \\
\text { communication } \\
\text { element }\end{array}$} & \multicolumn{3}{|c|}{ Task Information } & \multicolumn{3}{|c|}{ Personal Information } & \multicolumn{3}{|c|}{ Concreteness } & \multicolumn{3}{|c|}{ Affective Intensity } \\
\hline & $\begin{array}{c}\text { Low } \\
\text { degree }\end{array}$ & $\begin{array}{c}\text { Moderate } \\
\text { degree }\end{array}$ & $\begin{array}{c}\text { High } \\
\text { degree }\end{array}$ & $\begin{array}{c}\text { Low } \\
\text { degree }\end{array}$ & $\begin{array}{c}\text { Moderate } \\
\text { degree }\end{array}$ & $\begin{array}{c}\text { High } \\
\text { degree }\end{array}$ & $\begin{array}{c}\text { Low } \\
\text { degree }\end{array}$ & $\begin{array}{c}\text { Moderate } \\
\text { degree }\end{array}$ & $\begin{array}{c}\text { High } \\
\text { degree }\end{array}$ & $\begin{array}{c}\text { Low } \\
\text { degree }\end{array}$ & $\begin{array}{c}\text { Moderate } \\
\text { degree }\end{array}$ & $\begin{array}{c}\text { High } \\
\text { degree }\end{array}$ \\
\hline $\begin{array}{l}\text { Mean Mimicry } \\
\text { by Freelancer }\end{array}$ & .446 & .759 & .617 & .349 & .443 & .423 & .505 & .798 & .724 & .443 & .446 & .438 \\
\hline $\mathrm{SD}$ & .335 & .196 & .247 & .476 & .290 & .383 & .361 & .268 & .227 & .499 & .381 & .380 \\
\hline Relation & & $\cap$ & & & $\cap$ & & & $\cap$ & & & no relation & \\
\hline
\end{tabular}

Note: Here, we only considered bids that won. We split the bids between those which replied to a buyer that used (1) a low degree $(<10 \%$ of range of observed values), $(2)$ moderate degree ( $45 \%-55 \%$ of range of observed values), and (3) high degree ( $>90 \%$ of range of observed values), of the respective communicative element (i.e., task information, 
personal information, concreteness, or affective intensity) across all 5,167,787 bids (4,712,990 bids were unsuccessful; 454,797 bids were successful). We calculated the difference between each bid's (b) use of each respective communication element $(\mathrm{C})$ and the respective call for bids' (cfb) use of the same communication element (C) using the same formula as Ludwig et al. (2013) when they calculated the linguistic style match. Specifically Mimicry of $\mathrm{C}_{b}=1-\left[\mid\left(\mathrm{C}_{b}-\mathrm{C}_{\mathrm{cfb}}\right) /\left(\mathrm{C}_{\mathrm{b}}+\mathrm{C}_{\mathrm{cfb}}+0.0001\right]\right.$. The resulting similarity score is bounded by 0 and 1 for each bid, higher numbers represented greater similarity (or mimicry) by the freelancer towards the buyer's use of the respective communication element. We split the reporting of the average differences for all bids which were submitted in response to (1) call for bids that used the communication element to a less degree, ( 2 ) moderate degree, and (3) great degree.

\section{Table WA H4. Model Free Evidence for Price Premium}

\begin{tabular}{|c|c|c|c|c|c|c|c|c|}
\hline \multirow[b]{2}{*}{ Price Premium } & \multicolumn{2}{|c|}{ Task Information } & \multicolumn{2}{|c|}{ Personal Information } & \multicolumn{2}{|c|}{ Concreteness } & \multicolumn{2}{|c|}{ Affective Intensity } \\
\hline & No & Yes & No & Yes & No & Yes & No & Yes \\
\hline Mean & .224 & .248 & .064 & .069 & .183 & .200 & .048 & .042 \\
\hline SD & .140 & .193 & .051 & .064 & .094 & .077 & .064 & .075 \\
\hline t-test & \multicolumn{2}{|c|}{-12.05} & \multicolumn{2}{|c|}{-7.015} & \multicolumn{2}{|c|}{-13.65} & \multicolumn{2}{|c|}{6.78} \\
\hline P-value & \multicolumn{2}{|c|}{$p<.001$} & \multicolumn{2}{|c|}{$p<.001$} & \multicolumn{2}{|c|}{$p<.001$} & \multicolumn{2}{|c|}{$p<.001$} \\
\hline
\end{tabular}

Note: We split bids between those with a price below the asking price (“discount") and those above the asking price ("premium"; 45,841 bids were below and 6,207 bids were above, the rest matched the asking price).

\section{Table WA H5. Model Free Evidence for Bids’ Price Premium and Mimicry of Communication Elements}

\begin{tabular}{|c|c|c|c|c|c|c|c|c|c|c|c|c|}
\hline \multirow[b]{2}{*}{$\begin{array}{l}\text { Buyer's use of } \\
\text { communication } \\
\text { element }\end{array}$} & \multicolumn{3}{|c|}{ Task Information } & \multicolumn{3}{|c|}{ Personal Information } & \multicolumn{3}{|c|}{ Concreteness } & \multicolumn{3}{|c|}{ Affective Intensity } \\
\hline & $\begin{array}{c}\text { Low } \\
\text { degree }\end{array}$ & $\begin{array}{c}\text { Moderate } \\
\text { degree }\end{array}$ & $\begin{array}{c}\text { High } \\
\text { degree }\end{array}$ & $\begin{array}{c}\text { Low } \\
\text { degree }\end{array}$ & $\begin{array}{c}\text { Moderate } \\
\text { degree }\end{array}$ & $\begin{array}{c}\text { High } \\
\text { degree }\end{array}$ & $\begin{array}{c}\text { Low } \\
\text { degree }\end{array}$ & $\begin{array}{c}\text { Moderate } \\
\text { degree }\end{array}$ & $\begin{array}{c}\text { High } \\
\text { degree }\end{array}$ & $\begin{array}{c}\text { Low } \\
\text { degree }\end{array}$ & $\begin{array}{l}\text { Moderate } \\
\text { degree }\end{array}$ & $\begin{array}{c}\text { High } \\
\text { degree }\end{array}$ \\
\hline $\begin{array}{l}\text { Mean Mimicry } \\
\text { by Freelancer }\end{array}$ & .722 & .812 & .703 & .261 & .398 & .508 & .521 & .745 & .613 & .267 & .591 & .505 \\
\hline $\mathrm{SD}$ & .344 & .201 & .212 & .438 & .299 & .347 & .329 & .327 & .283 & .442 & .351 & .328 \\
\hline Relation & & $\cap$ & & & I & & & $\cap$ & & & $\cap$ & \\
\hline
\end{tabular}

Note: Here, we only considered bids that received a price premium. We split the bids between those which replied to a buyer that used $(1)$ a low degree $(<10 \%$ of range of observed values), (2) moderate degree (45\%-55\% of range of observed values), and (3) high degree( $>90 \%$ of range of observed values), of the respective communicative element (i.e. task information, personal information, concreteness, or affective intensity). 45,841 bids were below and 6,207 bids were above, the rest matched the asking price. We calculated the difference between each bid's (b) use of each respective communication element (C) and the respective call for bids' (cfb) use of the same communication element (C) using the same formula as Ludwig et al. (2013) when they calculated the linguistic style match. Specifically Mimicry of $\mathrm{C}_{b}=1-\left[\mid\left(\mathrm{C}_{b}-\mathrm{C}_{\mathrm{cfb}}\right) / /\left(\mathrm{C}_{\mathrm{b}}+\mathrm{C}_{\mathrm{cfb}}+0.0001\right]\right.$. The resulting similarity score is bounded by 0 and 1 for each bid, higher numbers represented greater similarity (or mimicry) by the freelancer towards the buyer's use of the respective communication element. We split the reporting of the average differences for all bids which were submitted in response to (1) call for bids that used the communication element to a less degree, (2) moderate degree, and (3) great degree. 


\section{WA\#I: Latent Dirichlet Allocation to Account for Project Characteristics}

To account for potential project specifics which may (partly) explain the call-for bids or bids formulations and success, we used latent Dirichlet allocation (LDA; Blei 2012). LDA measures word co-occurrence across texts (e.g., keywords in freelancers' profile service descriptors), identifies latent topics, and the probability of each word appearing in a given topic.

To approximate the kind of project, we therefore used the skill keywords in freelancers service profile descriptors instead (see illustrative figure in Web Appendix D, the skill keywords are listed in Point 4). Specifically, any number of freelancers can apply to the same project. Overall, our reduced data comprises 343,796 unique projects. For each project, we concatenated all service skill tags keywords in from each applying freelancers' service profile who submitted a bid to the specific call for bids. These combined profile descriptor words were then processed using the R-package Quanteda (Benoit et al. 2018) to first remove punctuation, symbols, and English stopwords. Second, we stemmed the words. Third, we detected bigram collocations, such as "graphic design", and treat these as single tokens. We then formed a document-feature matrix from the tokens, and trimmed this to remove any terms that occurred fewer than 10 times, or in less than .001 percent of all documents. Following best practice (Blei 2012), we ran the structural topic model for $K=1$ to 20 topics. Fit measures (i.e., held-out likelihood, semantic coherence, residuals, and lower bound) revealed the best fit at $K=12$, so we fitted the $K=12$ topic model. We then estimated topic proportions per project, resulting in a vector of 12 control variables capturing the proportion of the applying freelancers' keyword service descriptors pertaining to each of the 12 latent topics extracted, see Table I1. We include a control for each of the 12 topic proportions to account for the project type. 
WA p. 24

\section{Table WA I1. Latent Project Characteristics derived from the LDA}

\begin{tabular}{ll}
\hline Topic & Top Word Stem Examples \\
\hline 1 & seo, sale, social media \\
2 & writer, editor, copywrit* \\
3 & consult*, manag*, analyst* \\
4 & translat*, proofread*, content writer \\
5 & artist, 3d, video editor \\
6 & web design, websit*, website design \\
7 & illustr*, programm*, architect* \\
8 & php, wordpress, html \\
9 & web develop*, communic*, ui \\
10 & account, support, project manag* \\
11 & photograph, video, audio \\
12 & data entr*, administr*, office \\
\hline
\end{tabular}




\section{WA\#J: Descriptive Statistics and Correlations}

Table WA J1. Descriptive Statistics and Correlations for Call for Bid Success

\begin{tabular}{|c|c|c|c|c|c|c|c|c|c|c|c|c|}
\hline & & 1 & 2 & 3 & 4 & 5 & 6 & 7 & 8 & 9 & 10 & 11 \\
\hline 1. & Call for bids success & & & & & & & & & & & \\
\hline 2. & Task information & .11 & & & & & & & & & & \\
\hline 3. & Personal information & -.07 & -.08 & & & & & & & & & \\
\hline 4. & Concreteness & .14 & -.07 & -.04 & & & & & & & & \\
\hline 5. & Affective intensity & -.11 & -.14 & .02 & -.13 & & & & & & & \\
\hline 6. & Word count & -.09 & -.23 & -.20 & -.02 & .07 & & & & & & \\
\hline 7. & Buyer experience & -.08 & .01 & -.01 & -.02 & .01 & .02 & & & & & \\
\hline 8. & Project payment & .13 & .02 & -.07 & .03 & -.04 & .06 & -.02 & & & & \\
\hline 9. & Payment not disclosed & .22 & .00 & .02 & .10 & -.06 & -.13 & -.06 & -.10 & & & \\
\hline 10. & Project duration & .47 & .12 & -.06 & .21 & -.16 & -.18 & -.08 & .14 & .37 & & \\
\hline \multirow[t]{3}{*}{10.} & Excess supply of freelancers & .21 & .09 & .05 & .08 & -.13 & -.18 & -.07 & .07 & .12 & .23 & \\
\hline & Mean & 4.92 & .26 & .03 & .20 & .04 & 125.60 & 11.18 & 57.58 & .15 & .33 & 7.25 \\
\hline & SD & 8.37 & .08 & .03 & .07 & .03 & 93.57 & 20.00 & 230.32 & .35 & .47 & 2.27 \\
\hline
\end{tabular}

Note: Observations $=343,796$.

*Please note that there is a non-disclosure agreement is in place for the secondary data restricting the disclosure of confidential information. 


\section{Table WA J2. Descriptive Statistics and Correlations for Bid Success}

WA p. 26

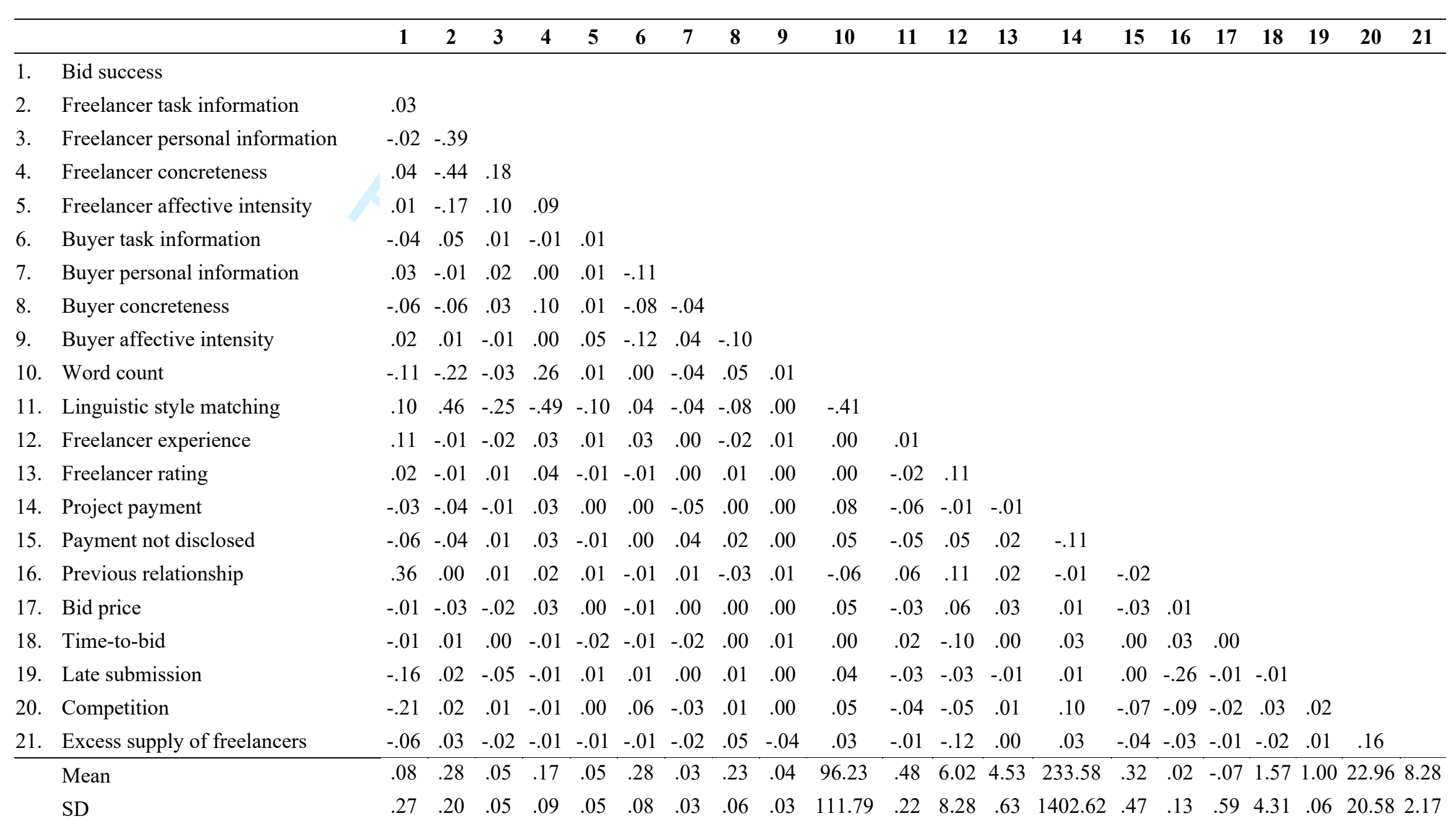

Note: Observations $=2,327,216$.

*Please note that there is a non-disclosure agreement is in place for the secondary data restricting the disclosure of confidential information. 


\section{Table WA J3. Descriptive Statistics and Correlations for Price Premium}

\begin{tabular}{|c|c|c|c|c|c|c|c|c|c|c|c|c|c|c|c|c|c|c|c|c|}
\hline & & 1 & 2 & 3 & 4 & 5 & 6 & 7 & 8 & 9 & 10 & 11 & 12 & 13 & 14 & 15 & 16 & 17 & 18 & 19 \\
\hline 1. & Price premium & & & & & & & & & & & & & & & & & & & \\
\hline 2. & Freelancer task information & .25 & & & & & & & & & & & & & & & & & & \\
\hline 3. & Freelancer personal information & -.20 & -.48 & & & & & & & & & & & & & & & & & \\
\hline 4. & Freelancer concreteness & -.10 & -.21 & .03 & & & & & & & & & & & & & & & & \\
\hline 5. & Freelancer affective intensity & .00 & -.06 & -.07 & -.05 & & & & & & & & & & & & & & & \\
\hline 6. & Buyer task information & .00 & .09 & .02 & -.06 & .01 & & & & & & & & & & & & & & \\
\hline 7. & Buyer personal information & .10 & .08 & -.04 & -.01 & -.02 & -.09 & & & & & & & & & & & & & \\
\hline 8. & Buyer concreteness & -.13 & -.14 & .09 & .32 & .00 & -.10 & -.06 & & & & & & & & & & & & \\
\hline 9. & Buyer affective intensity & .06 & .06 & -.06 & -.04 & .11 & -.10 & .03 & -.12 & & & & & & & & & & & \\
\hline 10. & Word count & -.27 & -.27 & .11 & .18 & -.01 & -.02 & -.09 & .15 & -.04 & & & & & & & & & & \\
\hline 11. & Linguistic style matching & .27 & .42 & -.25 & -.28 & -.01 & -.06 & .01 & -.18 & .09 & -.49 & & & & & & & & & \\
\hline 12. & Freelancer experience & .13 & .09 & -.11 & -.03 & .02 & .00 & .01 & -.06 & .05 & -.11 & .14 & & & & & & & & \\
\hline 13. & Freelancer rating & -.03 & -.05 & .05 & .04 & -.01 & -.01 & -.02 & .04 & -.03 & .04 & -.05 & .10 & & & & & & & \\
\hline 14. & Project payment & -.21 & -.09 & .05 & .05 & .00 & .00 & -.08 & .05 & -.03 & .15 & -.11 & -.03 & .02 & & & & & & \\
\hline 15. & Previous relationship & .05 & -.01 & .02 & -.02 & .02 & .04 & .00 & -.04 & .00 & -.15 & .09 & .13 & .06 & -.01 & & & & & \\
\hline 16. & Time-to-bid & -.08 & -.11 & .18 & .02 & -.04 & .00 & -.04 & .03 & -.01 & .00 & -.01 & -.03 & .02 & .06 & .13 & & & & \\
\hline 17. & Late submission & .00 & .09 & -.15 & .01 & .03 & -.01 & .02 & .00 & .01 & .06 & -.02 & -.03 & -.04 & -.02 & -.23 & -.04 & & & \\
\hline 18. & Competition & -.24 & -.16 & .20 & .05 & -.03 & .04 & -.12 & .12 & -.05 & .22 & -.18 & -.09 & .05 & .13 & -.05 & .17 & -.13 & & \\
\hline 19. & Excess supply of freelancers & -.19 & -.06 & .08 & .05 & .00 & .02 & -.02 & .10 & -.08 & .13 & -.14 & -.16 & .05 & .07 & -.03 & .02 & .01 & .16 & \\
\hline & Mean & -.13 & .32 & .04 & .18 & .05 & .27 & .03 & .21 & .04 & 51.20 & .57 & 9.07 & 4.57 & 96.25 & .18 & 1.14 & .97 & 7.36 & 7.79 \\
\hline & $\mathrm{SD}$ & .26 & .21 & .05 & .10 & .08 & .08 & .03 & .07 & .03 & 86.14 & .23 & 10.50 & .57 & 328.12 & .38 & 3.71 & .18 & 10.72 & 2.23 \\
\hline
\end{tabular}

Note: Observations $=148,158$.

*Please note that there is a non-disclosure agreement is in place for the secondary data restricting the disclosure of confidential information. 


\section{WA\#K: Response Surface Coefficients}

\begin{tabular}{|c|c|c|c|c|c|c|}
\hline & \multicolumn{3}{|c|}{$\begin{array}{c}\text { Model 4: } \\
\text { Bid Success }\end{array}$} & \multicolumn{3}{|c|}{$\begin{array}{c}\text { Model 6: } \\
\text { Price Premium }\end{array}$} \\
\hline & $\beta$ & SE & $95 \% \mathrm{CI}$ & $\beta$ & SE & 95\% CI \\
\hline \multicolumn{7}{|l|}{ Task Information } \\
\hline Fit line slope $\left(\mathrm{y}_{01}+\mathrm{y}_{05}\right)$ & $.006 * *$ & .001 & $.005, .008$ & $.025 * *$ & .002 & $.021, .028$ \\
\hline Fit line curvature $\left(\mathrm{y}_{09}+\mathrm{y}_{13}+\mathrm{y}_{17}\right)$ & $.010 * *$ & .001 & $.009, .011$ & $.027 * *$ & .002 & $.025, .029$ \\
\hline Misfit line slope $\left(\mathrm{y}_{01}-\mathrm{y}_{05}\right)$ & $.023 * *$ & .001 & $.022, .025$ & $.019 * *$ & .002 & $.015, .023$ \\
\hline Misfit line curvature $\left(\mathrm{y}_{09}-\mathrm{y}_{13}+\mathrm{y}_{17}\right)$ & $-.020 * *$ & .000 & $-.021,-.019$ & $-.023 * *$ & .001 & $-.025,-.021$ \\
\hline Slope at low level of buyer's task information $\left(\mathrm{y}_{01}-1.5 \mathrm{SDy}_{13}\right)$ & $-.008 * *$ & .001 & $-.009,-.007$ & $-.016 * *$ & -.003 & $-.017,-.015$ \\
\hline Slope at high level of buyer's task information $\left(\mathrm{y}_{01}+1.5 \mathrm{SDy}_{13}\right)$ & $.038 * *$ & .001 & $.037, .040$ & $.060 * *$ & .007 & $.055, .066$ \\
\hline \multicolumn{7}{|l|}{ Personal Information } \\
\hline Fit line slope $\left(\mathrm{y}_{02}+\mathrm{y}_{06}\right)$ & .000 & .001 & $-.001, .001$ & $.006^{*}$ & .003 & $.003, .009$ \\
\hline Fit line curvature $\left(\mathrm{y}_{10}+\mathrm{y}_{14}+\mathrm{y}_{17}\right)$ & $-.011 * *$ & .000 & $-.012,-.01$ & $-.004 *$ & .002 & $-.007,-.001$ \\
\hline Misfit line slope $\left(\mathrm{y}_{02}-\mathrm{y}_{06}\right)$ & $-.035 * *$ & .001 & $.033, .037$ & .037 & .003 & $.032, .042$ \\
\hline Misfit line curvature $\left(\mathrm{y}_{10}-\mathrm{y}_{14}+\mathrm{y}_{17}\right)$ & $-.007 * *$ & .000 & $-.006,-.008$ & $.003 *$ & .002 & $.008, .014$ \\
\hline Slope at low level of buyer's personal information $\left(\mathrm{y}_{02}-1.5 \mathrm{SDy}_{14}\right)$ & $.020 * *$ & .001 & $.019, .020$ & $.027 * *$ & .001 & $.025, .029$ \\
\hline Slope at high level of buyer's personal information $\left(\mathrm{y}_{02}+1.5 \mathrm{SDy}_{14}\right)$ & $.014 * *$ & .001 & $.013, .016$ & $.015 * *$ & .004 & $.009, .023$ \\
\hline \multicolumn{7}{|l|}{ Concreteness } \\
\hline Fit line slope $\left(\mathrm{y}_{03}+\mathrm{y}_{07}\right)$ & $.023 * *$ & .001 & $.022, .024$ & .001 & .001 & $-.006, .008$ \\
\hline Fit line curvature $\left(\mathrm{y}_{11}+\mathrm{y}_{15}+\mathrm{y}_{19}\right)$ & $-.001 * *$ & .000 & $-.001, .000$ & $-.002 * *$ & .001 & $-.004,-.001$ \\
\hline Misfit line slope $\left(\mathrm{y}_{03}-\mathrm{y}_{07}\right)$ & $.040 * *$ & .001 & $.038, .041$ & $.009 * *$ & .003 & $.007, .011$ \\
\hline Misfit line curvature $\left(\mathrm{y}_{11}-\mathrm{y}_{15}+\mathrm{y}_{19}\right)$ & $-.011 * *$ & .000 & $-.011,-.010$ & $-.007 * *$ & .003 & $-.009,-.005$ \\
\hline Slope at low level of buyer's concreteness $\left(\mathrm{y}_{03}-1.5 \mathrm{SDy}_{15}\right)$ & $.024 * *$ & .001 & $.024, .025$ & .002 & .002 & $-.002, .004$ \\
\hline Slope at high level of buyer's concreteness $\left(\mathrm{y}_{03}+1.5 \mathrm{SDy}_{15}\right)$ & $.039 * *$ & .001 & $.036, .041$ & .008 & .001 & $-.005, .019$ \\
\hline \multicolumn{7}{|l|}{ Affective Intensity } \\
\hline Fit line slope $\left(\mathrm{y}_{04}+\mathrm{y}_{08}\right)$ & .001 & .001 & $-.001, .003$ & .002 & .003 & $-.004, .009$ \\
\hline Fit line curvature $\left(\mathrm{y}_{12}+\mathrm{y}_{16}+\mathrm{y}_{20}\right)$ & $.020 * *$ & .000 & $.020, .021$ & $.012 * *$ & .001 & $.011, .013$ \\
\hline Misfit line slope $\left(\mathrm{y}_{04}-\mathrm{y}_{08}\right)$ & -.002 & .001 & $-.003, .000$ & .004 & .004 & $-.003, .011$ \\
\hline Misfit line curvature $\left(\mathrm{y}_{12}-\mathrm{y}_{16}+\mathrm{y}_{20}\right)$ & $-.020 * *$ & .000 & $-.021,-.020$ & $-.008 * *$ & .001 & $-.01,-.006$ \\
\hline Slope at low level of buyer's intensity $\left(\mathrm{y}_{04}-1.5 \mathrm{SDy}_{16}\right)$ & $-.030 * *$ & .001 & $-.031,-.030$ & $-.012 * *$ & .002 & $-.015,-.009$ \\
\hline Slope at high level of buyer's intensity $\left(\mathrm{y}_{04}+1.5 \mathrm{SDy}_{16}\right)$ & $.030 * *$ & .001 & $.028, .032$ & $.018 * *$ & .005 & $.009, .027$ \\
\hline
\end{tabular}

${ }^{* *} p<.01,{ }^{*} p<.05$. Significance is based on two-tailed tests. 


\section{WA\#L: Effect of Matching the Buyers' Communication on Bid Success}

A. Similarity and Dissimilarity of Task Information

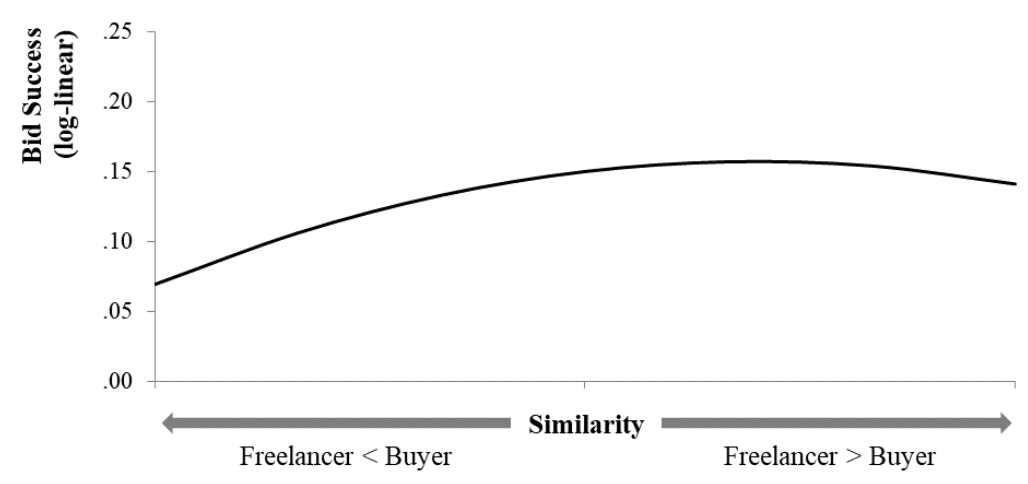

C. Similarity and Dissimilarity of Concreteness

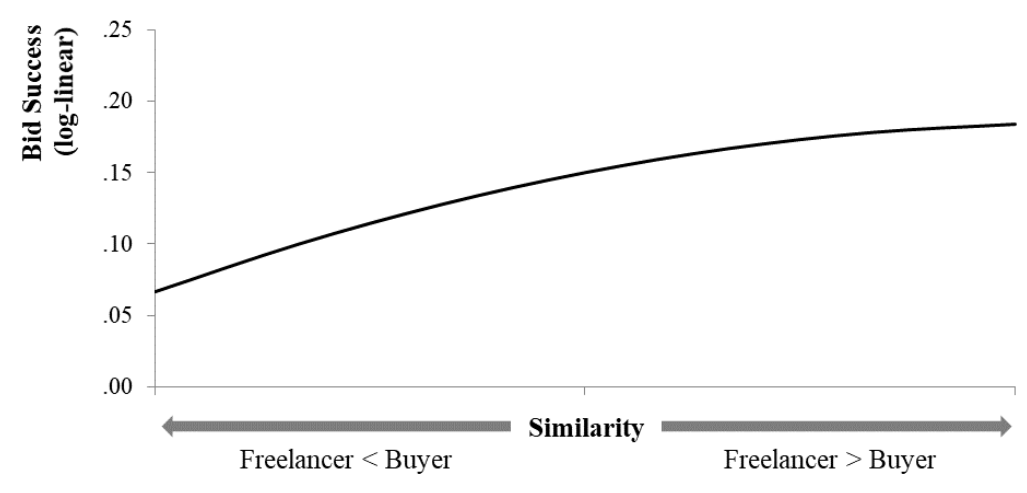

B. Similarity and Dissimilarity of Personal Information

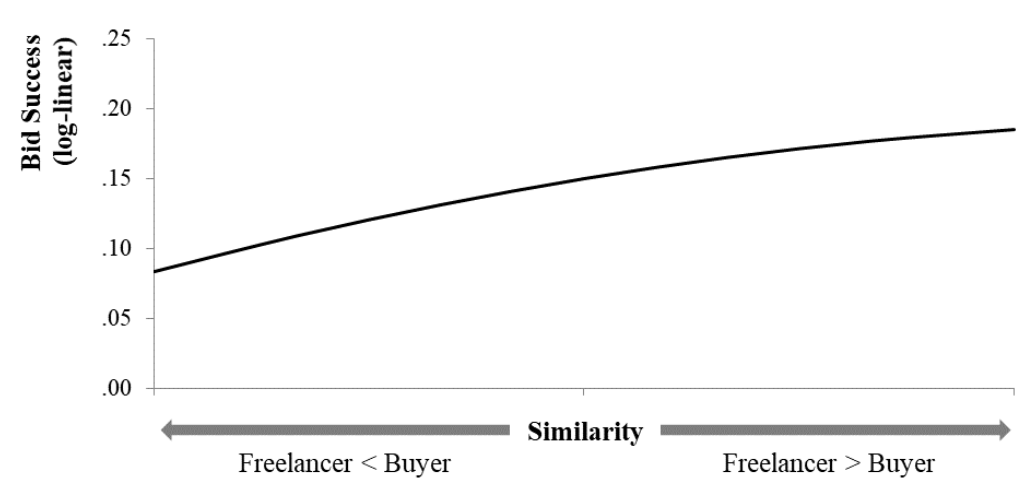

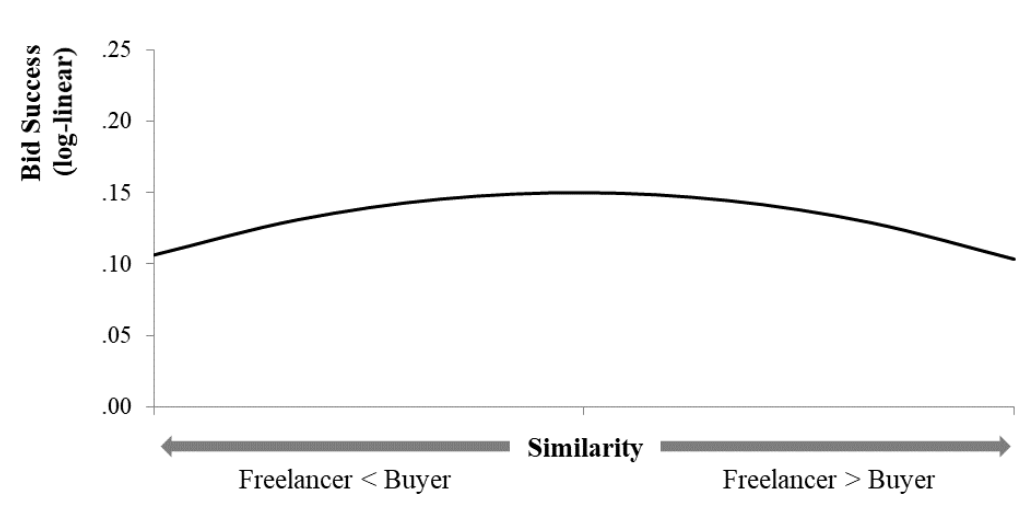




\section{WA\#M: Low vs. High Levels of Buyers' Communication and Bid Success}

A. Low and High Levels of Buyers' Task Information

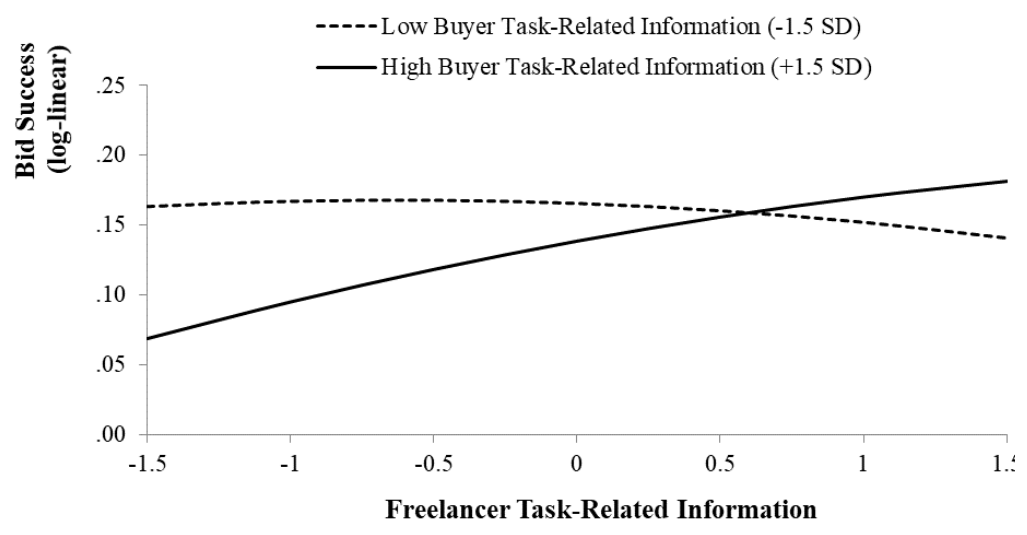

\section{Low and High Levels of Buyers' Concreteness}

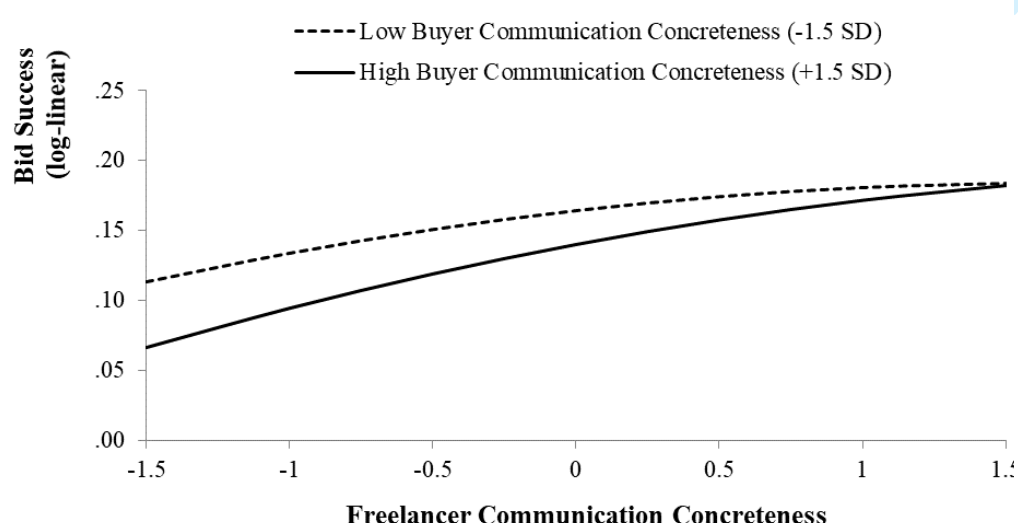

B. Low and High Levels of Buyers' Personal Information

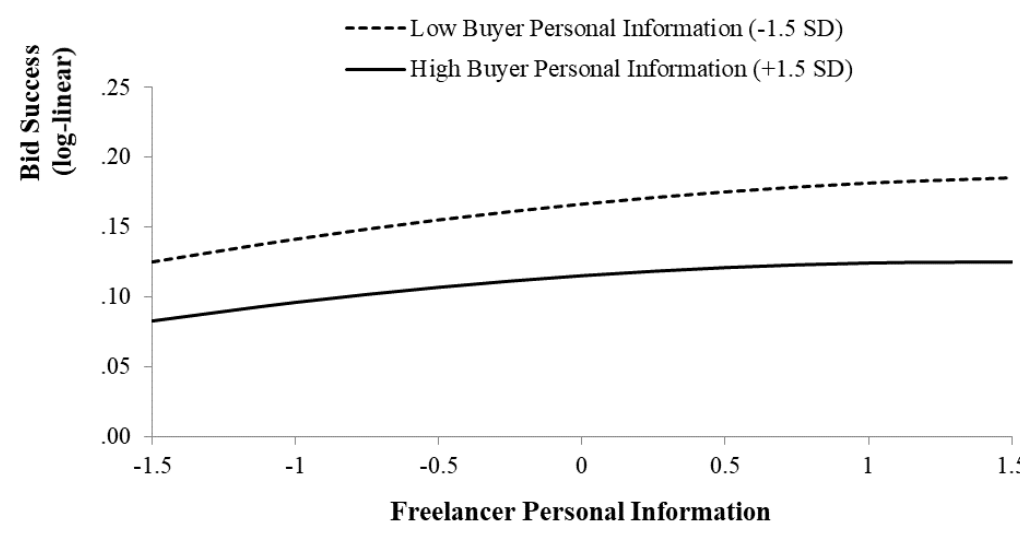

D. Low and High Levels of Buyers' Affective Intensity

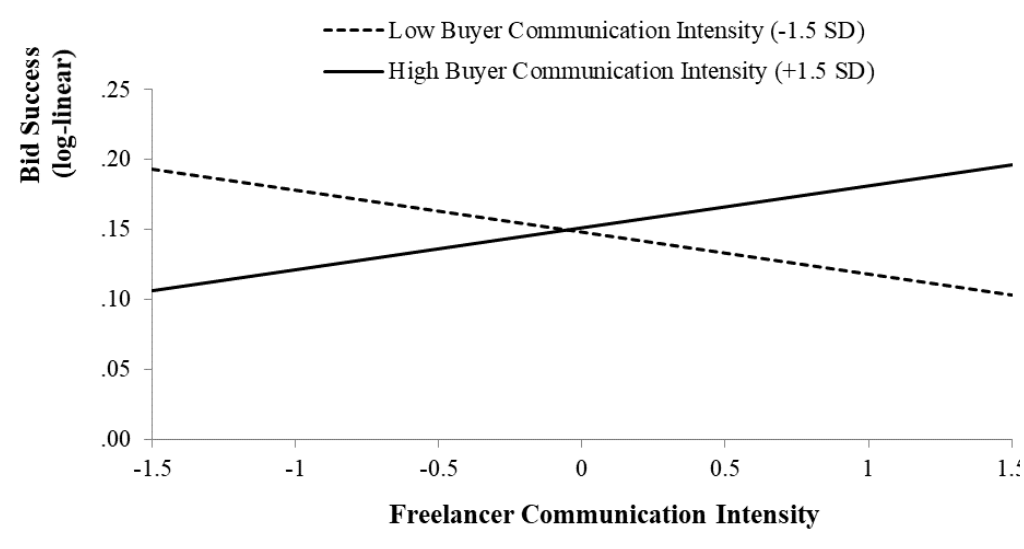


2

\section{WA\#N: Results for the Selection Model}

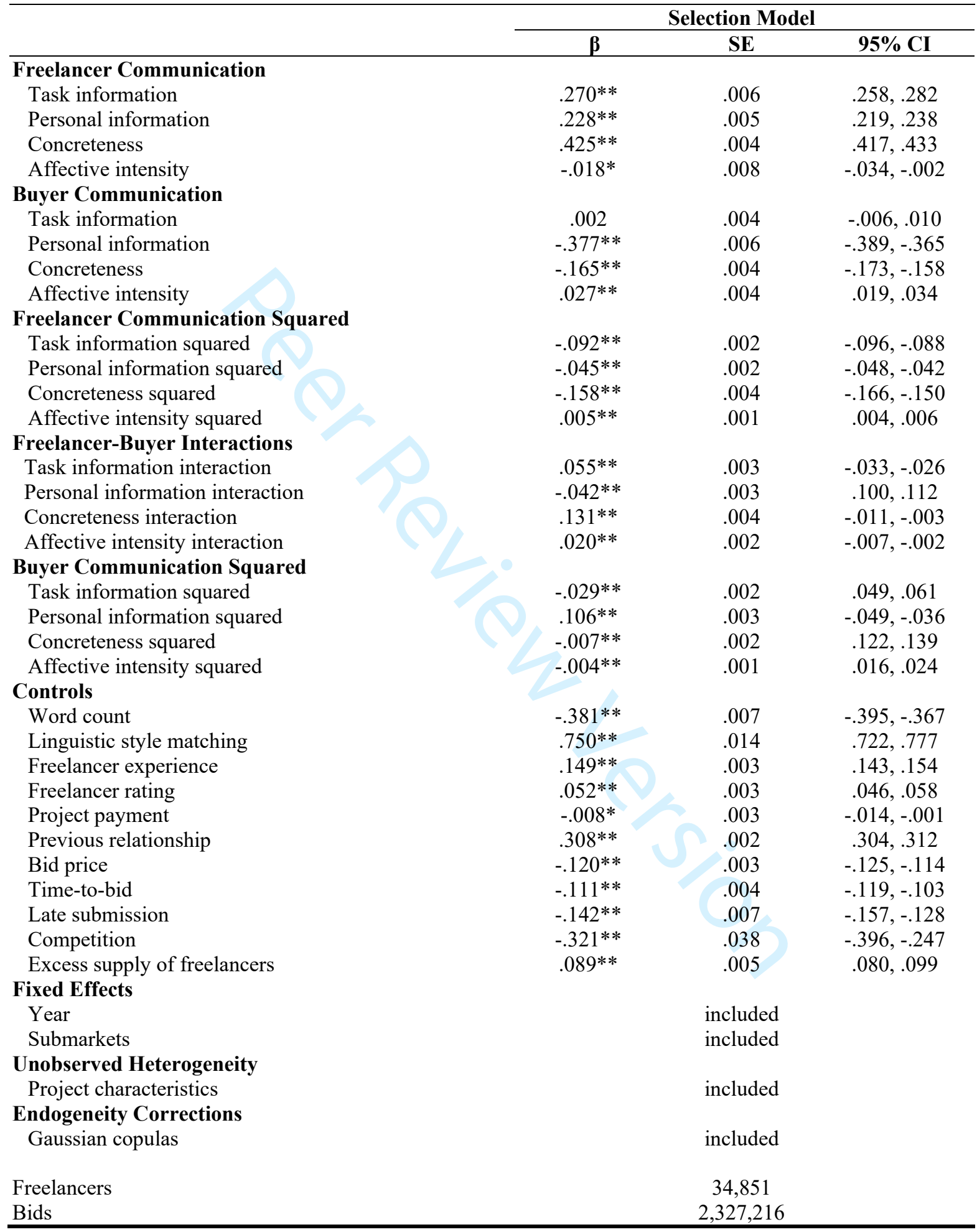

${ }^{* *} p<.01, * p<.05$. Significance is based on two-tailed tests. All variance inflation factors $<3.86$. 


\section{WA\#O: Effect of Matching the Buyers' Communication on Price Premium}

A. Similarity and Dissimilarity of Task Information

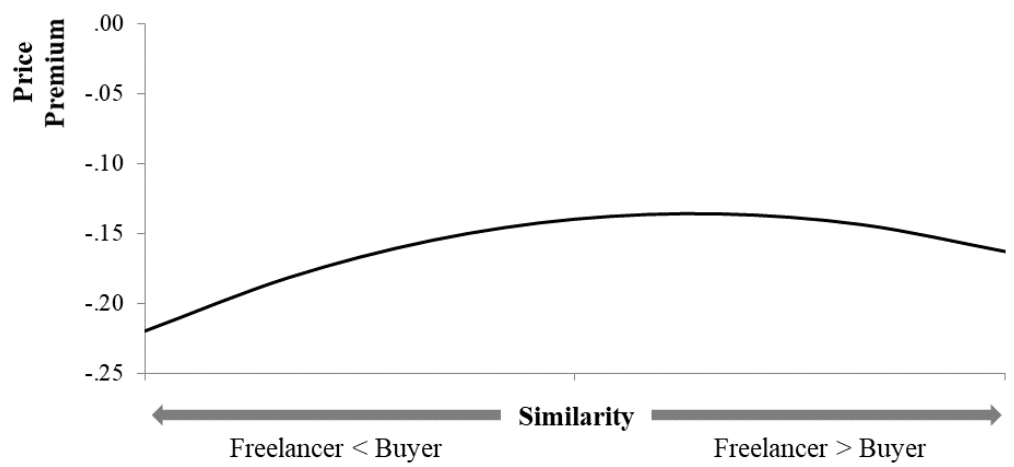

B. Similarity and Dissimilarity of Personal Information

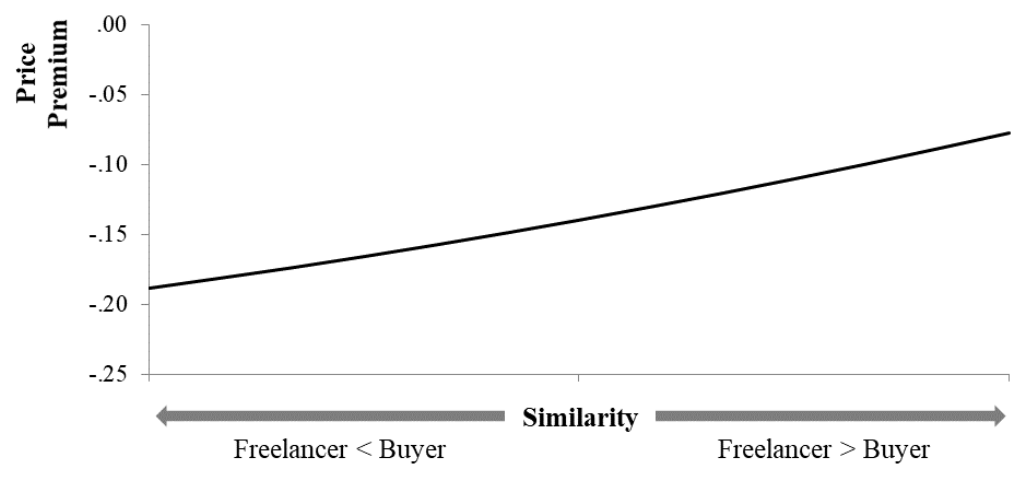

\section{Similarity and Dissimilarity of Concreteness}

这

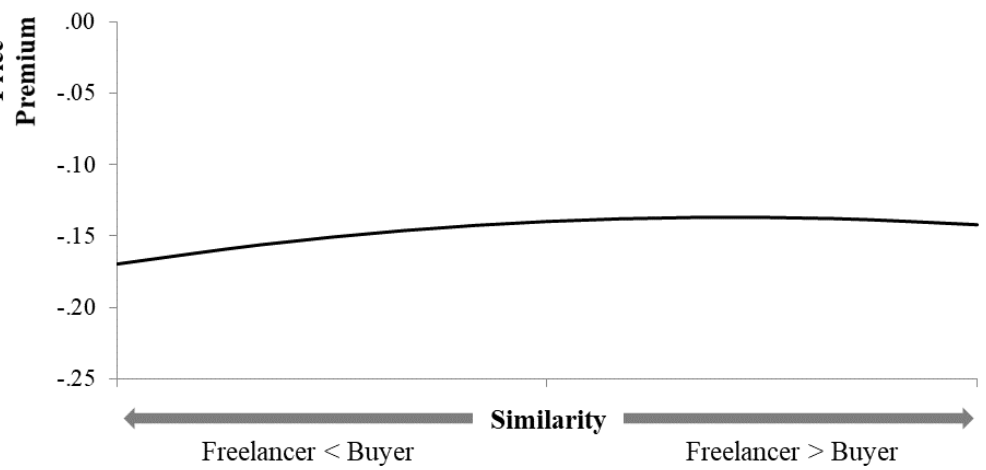

\section{Similarity and Dissimilarity of Affective Intensity}

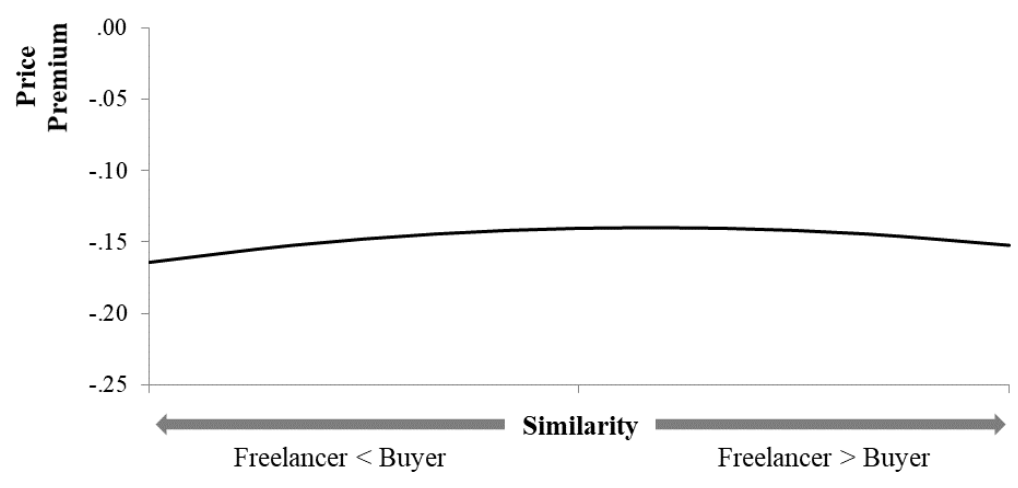




\section{WA\#P: Low vs. High Levels of Buyers' Communication and Price Premium}

A. Low and High Levels of Buyers' Task Information

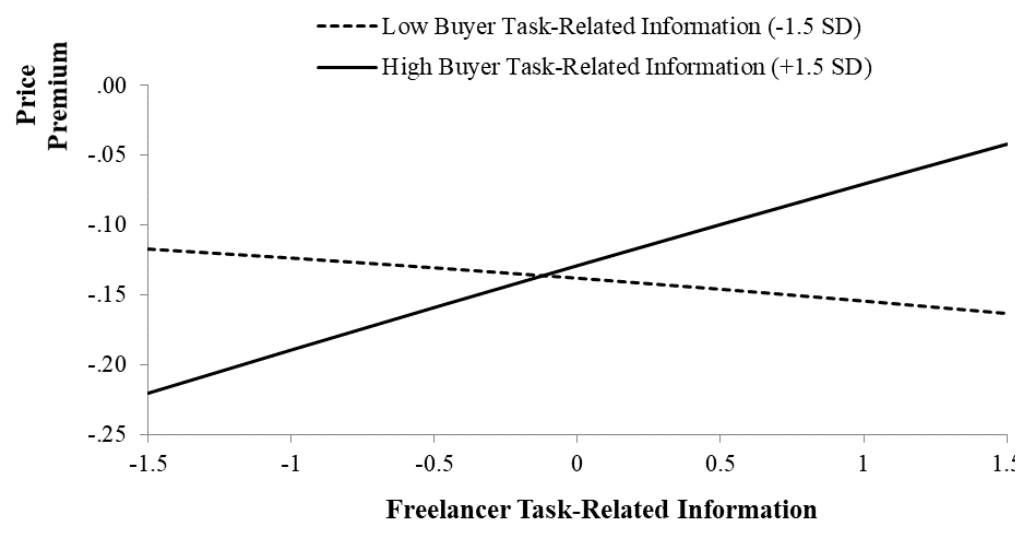

C. Low and High Levels of Buyers' Concreteness

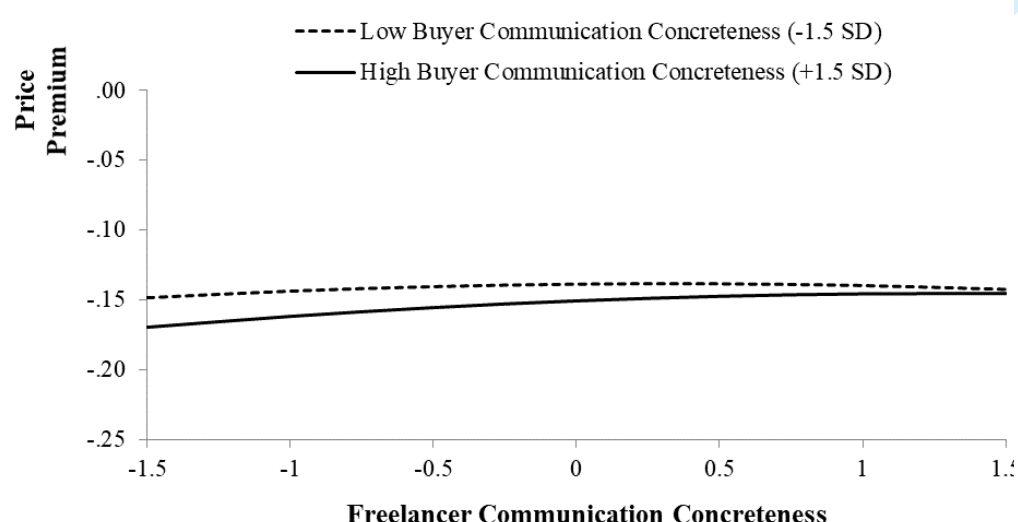

B. Low and High Levels of Buyers' Personal Information

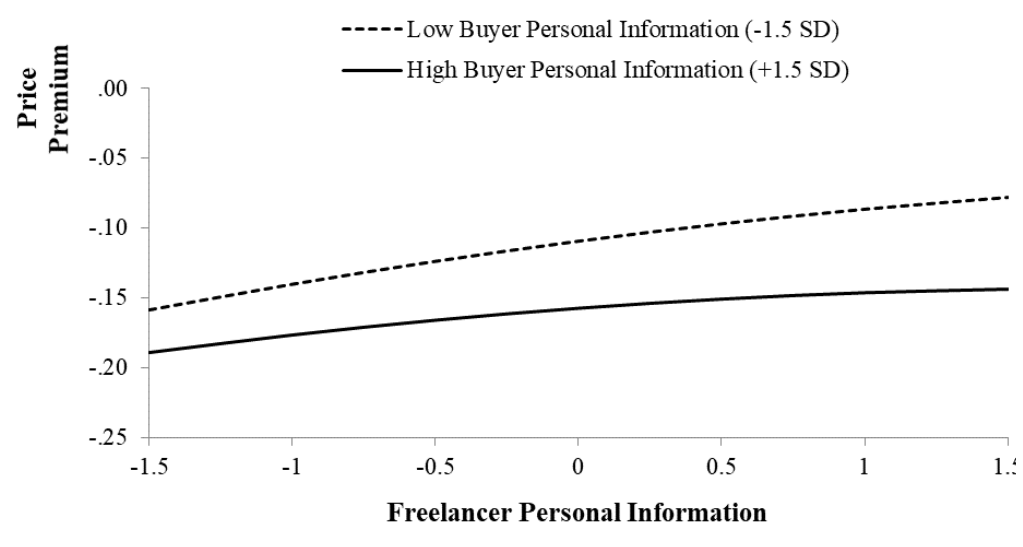

D. Low and High Levels of Buyers' Affective Intensity

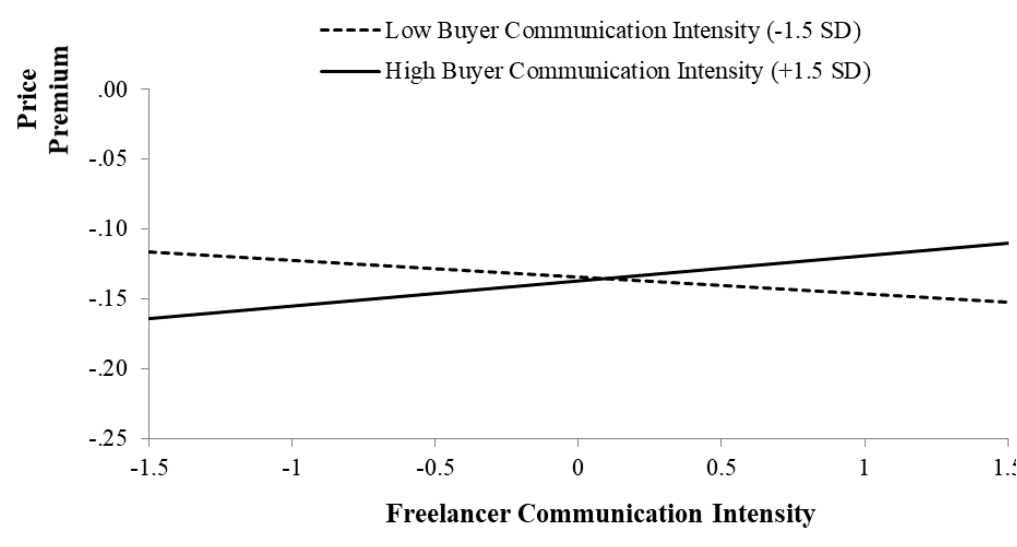




\section{WA\#Q: Additional Effects for All Analyses}

\section{Table WA Q1. Additional Effects for Buyers' Call for bids Success}

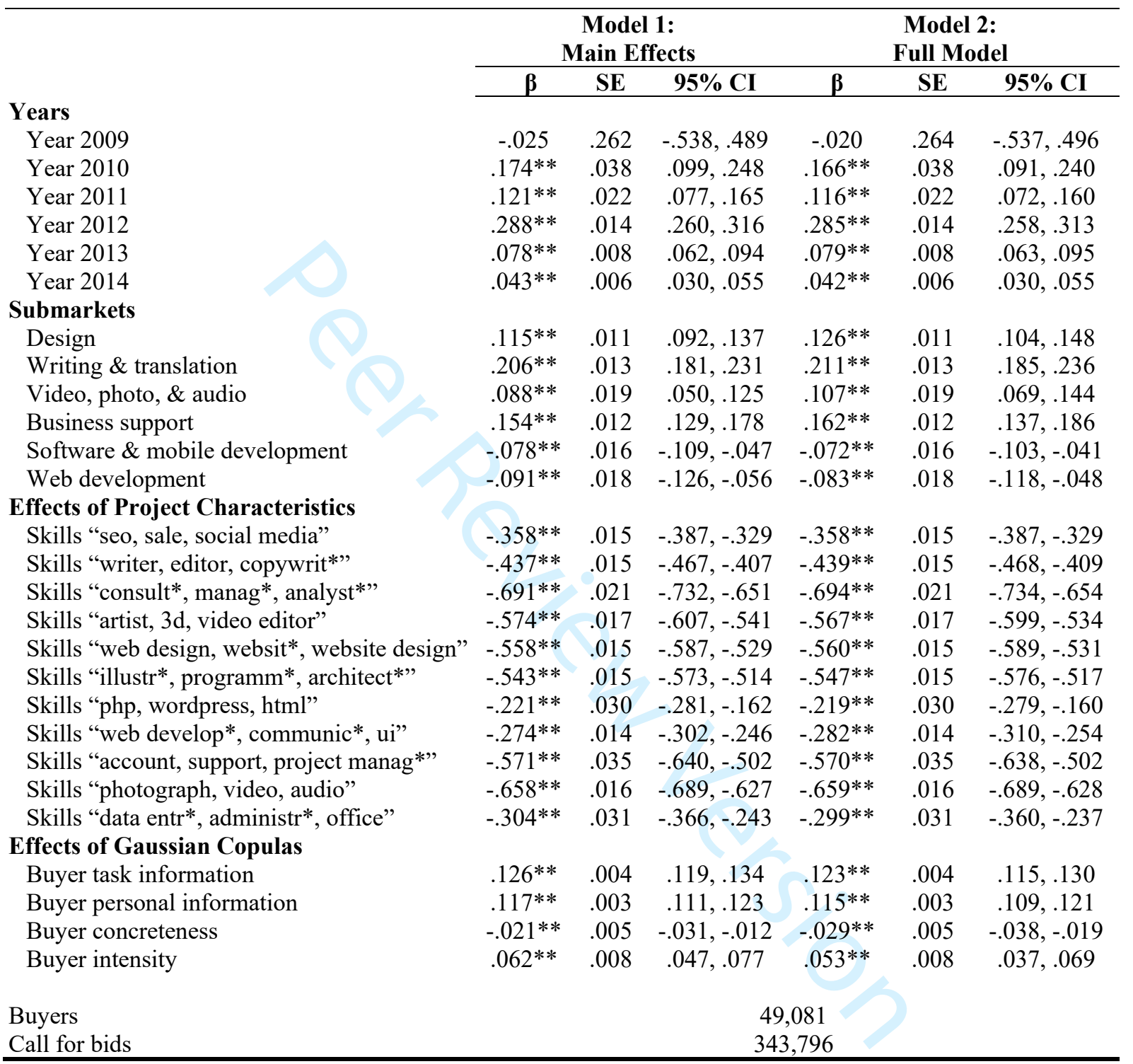

${ }^{* *} p<.01,{ }^{*} p<.05$. Significance is based on two-tailed tests. All variance inflation factors $<2.11$.

Notes: We omitted year $=2008$, submarket $=$ "social media, sales, $\&$ marketing", and project characteristics $=$ "translat*, proofread*, content writer". The dependent variable is the count of all bids received; the sample includes all projects listed by buyers with at least two projects to which at least one freelancer submitted a bid. 
Table WA Q2. Additional Effects for Freelancers' Bid Success

\begin{tabular}{|c|c|c|c|c|c|c|}
\hline & \multicolumn{3}{|c|}{$\begin{array}{c}\text { Model 3: } \\
\text { Freelancer Communication }\end{array}$} & \multicolumn{3}{|c|}{$\begin{array}{l}\text { Model 4: } \\
\text { Full Model }\end{array}$} \\
\hline & $\boldsymbol{\beta}$ & SE & 95\% CI & $\boldsymbol{\beta}$ & SE & $95 \% \mathrm{CI}$ \\
\hline \multicolumn{7}{|l|}{ Years } \\
\hline Year 2009 & $.026^{* *}$ & .000 & $.025, .026$ & $.025^{* *}$ & .000 & $.025, .026$ \\
\hline Year 2010 & .002 & .004 & $-.007, .010$ & -.001 & .004 & $-.010, .007$ \\
\hline Year 2011 & -.003 & .002 & $-.007, .001$ & $-.005^{*}$ & .002 & $-.008,-.001$ \\
\hline Year 2012 & $-.007 * *$ & .002 & $-.010,-.003$ & $-.008 * *$ & .002 & $-.011,-.005$ \\
\hline Year 2013 & $-.015^{* *}$ & .001 & $-.017,-.012$ & $-.016 * *$ & .001 & $-.019,-.014$ \\
\hline Year 2014 & $-.005 * *$ & .001 & $-.007,-.003$ & $-.007 * *$ & .001 & $-.009,-.005$ \\
\hline \multicolumn{7}{|l|}{ Submarkets } \\
\hline Design & $-.006 * *$ & .001 & $-.007,-.004$ & $-.006 * *$ & .001 & $-.007,-.004$ \\
\hline Writing \& translation & $-.050 * *$ & .003 & $-.055,-.045$ & $-.049 * *$ & .003 & $-.054,-.044$ \\
\hline Video, photo, \& audio & $-.042 * *$ & .003 & $-.047,-.037$ & $-.042 * *$ & .003 & $-.047,-.037$ \\
\hline Business support & $-.040 * *$ & .004 & $-.047,-.033$ & $-.041 * *$ & .003 & $-.047,-.034$ \\
\hline Software \& mobile development & $-.031 * *$ & .002 & $-.035,-.027$ & $-.033 * *$ & .002 & $-.037,-.028$ \\
\hline Web development & $-.024 * *$ & .002 & $-.029,-.020$ & $-.024 * *$ & .002 & $-.029,-.020$ \\
\hline \multicolumn{7}{|l|}{ Effects of Project Characteristics } \\
\hline Skills "seo, sale, social media" & $-.022 * *$ & .002 & $-.027,-.017$ & $-.023 * *$ & .002 & $-.028,-.018$ \\
\hline Skills "writer, editor, copywrit*" & $-.016^{* *}$ & .002 & $-.019,-.012$ & $-.016 * *$ & .002 & $-.019,-.012$ \\
\hline Skills "consult*, manag*, analyst*" & -.003 & .002 & $-.006, .001$ & -.002 & .002 & $-.005, .002$ \\
\hline Skills "artist, $3 \mathrm{~d}$, video editor" & $.014 * *$ & .003 & $.009, .020$ & $.015^{* *}$ & .003 & $.010, .020$ \\
\hline Skills "web design, websit*, website design" & $.027 * *$ & .002 & $.023, .032$ & $.026^{* *}$ & .002 & $.022, .031$ \\
\hline Skills "illustr*, programm*, architect*" & $.007 * *$ & .002 & $.003, .011$ & $.008^{* *}$ & .002 & $.004, .011$ \\
\hline Skills "php, wordpress, html" & $.011^{* *}$ & .002 & $.007, .015$ & $.013^{* *}$ & .002 & $.009, .017$ \\
\hline Skills "web develop*, communic*, ui" & $-.007 * *$ & .002 & $-.011,-.003$ & -.006 & .002 & $-.011,-.002$ \\
\hline Skills "account, support, project manag*" & $-.021 * *$ & .002 & $-.025,-.018$ & $-.019 * *$ & .002 & $-.022,-.016$ \\
\hline Skills "photograph, video, audio" & .006 & .003 & $-.001, .012$ & .006 & .003 & $-.001, .012$ \\
\hline Skills "data entr*, administr*, office" & $.023^{* *}$ & .002 & $.018, .027$ & $.023^{* *}$ & .002 & $.019, .028$ \\
\hline \multicolumn{7}{|l|}{ Effects of Gaussian Copulas } \\
\hline Freelancer task information & $-.013^{* *}$ & .003 & $-.019,-.008$ & $-.013 * *$ & .003 & $-.019,-.008$ \\
\hline Freelancer personal information & $-.031 * *$ & .001 & $-.033,-.029$ & $-.029 * *$ & .001 & $-.031,-.027$ \\
\hline Freelancer concreteness & $.008 * *$ & .001 & $.006, .009$ & $.007 * *$ & .001 & $.006, .009$ \\
\hline Freelancer intensity & $.010^{* *}$ & .000 & $.009, .011$ & $.010^{* *}$ & .000 & $.009, .010$ \\
\hline Buyer task information & & & & $-.005 * *$ & .001 & $-.007,-.003$ \\
\hline Buyer personal information & & & & $.005^{* *}$ & .000 & $.004, .005$ \\
\hline Buyer concreteness & & & & $-.007 * *$ & .000 & $-.008,-.007$ \\
\hline Buyer intensity & & & & $-.007 * *$ & .000 & $-.008,-.007$ \\
\hline Freela & & & & & & \\
\hline Bids & & & 2,32 & 7,216 & & \\
\hline
\end{tabular}

${ }^{* *} p<.01,{ }^{*} p<.05$. Significance is based on two-tailed tests. All variance inflation factors $<3.86$.

Notes: We omitted year $=2008$, submarket $=$ "social media, sales, $\&$ marketing", and project characteristics $=$ "translat*, proofread*, content writer". The dependent variable is whether the freelancer is chosen and wins the bidding process; the sample includes all bids by freelancers with at least one winning and at least one losing bid. 
Table WA Q3. Additional Effects for Freelancers' Price Premium

\begin{tabular}{|c|c|c|c|c|c|c|}
\hline & \multicolumn{3}{|c|}{$\begin{array}{c}\text { Model 5: } \\
\text { Freelancer Communication }\end{array}$} & \multicolumn{3}{|c|}{$\begin{array}{l}\text { Model 6: } \\
\text { Full Model }\end{array}$} \\
\hline & $\beta$ & $\mathbf{S E}$ & $95 \%$ CI & $\boldsymbol{\beta}$ & $\mathbf{S E}$ & $95 \%$ CI \\
\hline \multicolumn{7}{|l|}{ Years } \\
\hline Year 2009 & $-.012 * *$ & .002 & $-.016,-.009$ & $-.012 * *$ & .002 & $-.015,-.009$ \\
\hline Year 2010 & $-.027 * *$ & .002 & $-.030,-.023$ & $-.026 * *$ & .002 & $-.029,-.022$ \\
\hline Year 2011 & $-.020 * *$ & .002 & $-.023,-.017$ & $-.020 * *$ & .002 & $-.023,-.017$ \\
\hline Year 2012 & $-.021 * *$ & .001 & $-.024,-.018$ & $-.021 * *$ & .001 & $-.023,-.018$ \\
\hline Year 2013 & $-.007 * *$ & .001 & $-.009,-.004$ & $-.007 * *$ & .001 & $-.009,-.004$ \\
\hline Year 2014 & .000 & .002 & $-.005, .005$ & .000 & .002 & $-.005, .004$ \\
\hline \multicolumn{7}{|l|}{ Submarkets } \\
\hline Design & $.007 * *$ & .002 & $.003, .011$ & $.0073 *$ & .002 & $.004, .011$ \\
\hline Writing \& translation & -.002 & .001 & $-.005, .000$ & -.002 & .001 & $-.005, .000$ \\
\hline Video, photo, \& audio & $.008 * *$ & .002 & $.004, .012$ & $.007 * *$ & .002 & $.004, .011$ \\
\hline Business support & -.004 & .003 & $-.009, .001$ & -.004 & .003 & $-.009, .001$ \\
\hline Software \& mobile development & -.002 & .003 & $-.007, .003$ & -.002 & .003 & $-.007, .003$ \\
\hline Web development & $-.003 *$ & .002 & $-.006, .000$ & $-.003 *$ & .002 & $-.006, .000$ \\
\hline \multicolumn{7}{|l|}{ Effects of Project Characteristics } \\
\hline Skills "seo, sale, social media" & $-.006 * *$ & .002 & $-.009,-.002$ & $-.006^{* *}$ & .002 & $-.009,-.002$ \\
\hline Skills "writer, editor, copywrit*" & $-.003 * *$ & .001 & $-.006,-.001$ & $-.003 * *$ & .001 & $-.006,-.001$ \\
\hline Skills "consult*, manag*, analyst*" & -.003 & .002 & $-.006, .001$ & -.003 & .002 & $-.006, .000$ \\
\hline Skills "artist, $3 \mathrm{~d}$, video editor" & $-.011 * *$ & .002 & $-.015,-.007$ & $-.012 * *$ & .002 & $-.016,-.008$ \\
\hline Skills "web design, websit*, website design" & $-.008 * *$ & .002 & $-.012,-.004$ & $-.008 * *$ & .002 & $-.012,-.005$ \\
\hline Skills "illustr*, programm*, architect*" & $-.003 *$ & .001 & $-.005, .000$ & $-.003 *$ & .001 & $-.005, .000$ \\
\hline Skills "php, wordpress, html" & $-.018 * *$ & .002 & $-.022,-.013$ & $-.018 * *$ & .002 & $-.023,-.014$ \\
\hline Skills "web develop*, communic*, ui & .000 & .001 & $-.003, .002$ & -.001 & .001 & $-.003, .002$ \\
\hline Skills "account, support, project manag*" & $-.004 * *$ & .001 & $-.007,-.001$ & -.004 & .001 & $-.007,-.001$ \\
\hline Skills "photograph, video, audio" & -.002 & .001 & $-.004, .001$ & -.002 & .001 & $-.004, .001$ \\
\hline Skills "data entr*, administr*, office" & -.003 & .004 & $-.011, .006$ & -.004 & .004 & $-.013, .004$ \\
\hline \multicolumn{7}{|l|}{ Effects of Gaussian Copulas } \\
\hline Freelancer task information & $.009 * *$ & .002 & $.005, .012$ & $.009 * *$ & .002 & $.005, .012$ \\
\hline Freelancer personal information & $.003 * *$ & .001 & $.001, .005$ & $.003 * *$ & .001 & $.001, .005$ \\
\hline Freelancer concreteness & $-.015 * *$ & .003 & $-.020,-.010$ & $-.014 * *$ & .003 & $-.019,-.009$ \\
\hline Freelancer intensity & $-.014 * *$ & .001 & $-.016,-.011$ & $-.014 * *$ & .001 & $-.017,-.011$ \\
\hline Buyer task information & & & & -.001 & .002 & $-.004, .003$ \\
\hline Buyer personal information & & & & .002 & .001 & $-.001, .004$ \\
\hline Buyer concreteness & & & & $.005^{* *}$ & .002 & $.002, .008$ \\
\hline Buyer intensity & & & & $-.036^{* *}$ & .003 & $-.042,-.030$ \\
\hline Freela & & & & & & \\
\hline Bids & & & & 158 & & \\
\hline
\end{tabular}

${ }^{* *} p<.01,{ }^{*} p<.05$. Significance is based on two-tailed tests. All variance inflation factors $<2.74$.

Notes: We omitted year $=2008$, submarket $=$ "social media, sales, $\&$ marketing", and project characteristics $=$ "translat*, proofread*, content writer". The dependent variable is price premium for the chosen bid; the sample includes all winning bids where the payment was disclosed. 
2

3

4

5

6

7

8

9

\section{WA\#R: Robustness Test: Predicting Freelancers’ Bid Success}

\begin{tabular}{|c|c|c|c|c|c|c|}
\hline & \multicolumn{3}{|c|}{$\begin{array}{c}\text { Model 7: } \\
\text { Freelancer Communication }\end{array}$} & \multicolumn{3}{|c|}{$\begin{array}{l}\text { Model 8: } \\
\text { Full Model }\end{array}$} \\
\hline & $\beta$ & SE & $95 \% \mathrm{CI}$ & $\beta$ & SE & $95 \% \mathrm{CI}$ \\
\hline \multicolumn{7}{|l|}{ Freelancer Communication } \\
\hline $\mathrm{y}_{01}$ : Task information & $.014 * *$ & .001 & $.013, .015$ & $.016^{* *}$ & .001 & $.015, .017$ \\
\hline $\mathrm{y}_{02}$ : Personal information & $.018^{* *}$ & .001 & $.017, .019$ & $.017 * *$ & .001 & $.016, .018$ \\
\hline $\mathrm{y}_{03}$ : Concreteness & $.028^{* *}$ & .000 & $.028, .028$ & $.029^{* *}$ & .000 & $.029, .029$ \\
\hline $\mathrm{y}_{04}$ : Affective intensity & $.003 * *$ & .001 & $.002, .004$ & .001 & .001 & $.000, .002$ \\
\hline \multicolumn{7}{|l|}{ Buyer Communication } \\
\hline $\mathrm{y}_{05}$ : Task information & & & & $-.009^{* *}$ & .000 & $-.009,-.009$ \\
\hline $\mathrm{y}_{06}$ : Personal information & & & & $-.016^{* *}$ & .000 & $-.016,-.016$ \\
\hline $\mathrm{y}_{07}:$ Concreteness & & & & $-.008 * *$ & .000 & $-.008,-.008$ \\
\hline yos: Affective intensity & & & & $.001 * *$ & .000 & $.001, .001$ \\
\hline \multicolumn{7}{|l|}{ Freelancer Communication Squared } \\
\hline $\mathrm{y}_{09}$ : Task information squared & $-.006^{* *}$ & .000 & $-.006,-.006$ & $-.006^{* *}$ & .000 & $-.006,-.006$ \\
\hline $\mathrm{y}_{10}$ : Personal information squared & $-.004 * *$ & .000 & $-.004,-.004$ & $-.004 * *$ & .000 & $-.004,-.004$ \\
\hline $\mathrm{y}_{11}:$ Concreteness squared & $-.006^{* *}$ & .000 & $-.006,-.006$ & $-.006^{* *}$ & .000 & $-.006,-.006$ \\
\hline $\mathrm{y}_{12}$ : Affective intensity squared & & .000 & $.000,0.00$ & $.000 * *$ & .000 & $.000, .000$ \\
\hline \multicolumn{7}{|l|}{ Freelancer-Buyer Interactions } \\
\hline $\mathrm{y}_{13}$ : Task information interaction & & & & $.002 * *$ & .000 & $.002, .002$ \\
\hline $\mathrm{y}_{14}:$ Personal information interaction & & & & $-.001 * *$ & .000 & $-.001,-.001$ \\
\hline $\mathrm{y}_{15}$ : Concreteness interaction & & & & $.005^{* *}$ & .000 & $.005, .005$ \\
\hline $\mathrm{y}_{16}:$ Intensity interaction & & & & $.002 * *$ & .000 & $.002, .002$ \\
\hline \multicolumn{7}{|l|}{ Buyer Communication Squared } \\
\hline $\mathrm{y}_{17}:$ Task information squared & & & & $.000^{* *}$ & .000 & $.000, .000$ \\
\hline $\mathrm{y}_{18}$ : Personal information squared & & & & $-.004 * *$ & .000 & $-.004,-.004$ \\
\hline $\mathrm{y}_{19}$ : Concreteness squared & & & & $.001 * *$ & .000 & $.001, .001$ \\
\hline $\mathrm{y}_{20}$ : Affective intensity squared & & & & $.000 * *$ & .000 & $.000, .000$ \\
\hline \multicolumn{7}{|l|}{ Controls } \\
\hline Word count & $-.020^{* *}$ & .001 & $-.021,-.019$ & $-.020 * *$ & .001 & $-.021,-.019$ \\
\hline Linguistic style matching & $.022 * *$ & .001 & $.021, .023$ & $.023^{* *}$ & .001 & $.022, .024$ \\
\hline Freelancer experience & $.003 * *$ & .001 & $.002, .004$ & $.003 * *$ & .001 & $.002, .004$ \\
\hline Freelancer rating & $.002 * *$ & .000 & $.002, .002$ & $.002 * *$ & .000 & $.002, .002$ \\
\hline Project payment & $-.001 * *$ & .000 & $-.001,-.001$ & $-.063 * *$ & .001 & $-.064,-.062$ \\
\hline Payment not disclosed & $-.027 * *$ & .000 & $-.027,-.027$ & $-.001 * *$ & .000 & $-.001,-.001$ \\
\hline Previous relationship & $.077 * *$ & .001 & $.076, .078$ & $-.027 * *$ & .000 & $-.027,-.027$ \\
\hline Bid price & $-.006^{* *}$ & .000 & $-.006,-.006$ & $.076^{* *}$ & .001 & $.075, .077$ \\
\hline Time-to-bid & .000 & .000 & $.000, .000$ & $-.006^{* *}$ & .000 & $-.006,-.006$ \\
\hline Late submission & $-.005^{* *}$ & .000 & $-.005,-.005$ & $-.004 * *$ & .000 & $-.004,-.004$ \\
\hline Competition & $-.252 * *$ & .007 & $-.259,-.245$ & $-.252 * *$ & .007 & $-.259,-.245$ \\
\hline Excess supply of freelancers & $-.040^{* *}$ & .000 & $-.04,-.04$ & $-.039 * *$ & .000 & $-.039,-.039$ \\
\hline \multicolumn{7}{|l|}{ Fixed Effects } \\
\hline Years & \multicolumn{3}{|c|}{ included } & \multicolumn{3}{|c|}{ included } \\
\hline Submarkets & \multicolumn{3}{|c|}{ included } & \multicolumn{3}{|c|}{ included } \\
\hline \multicolumn{7}{|l|}{ Unobserved Heterogeneity } \\
\hline Project characteristics & \multicolumn{3}{|c|}{ included } & \multicolumn{3}{|c|}{ included } \\
\hline \multicolumn{7}{|l|}{ Endogeneity Corrections } \\
\hline Gaussian copulas & & incl & & & incluc & \\
\hline
\end{tabular}

Freelancers 


\title{
WA\#S: Illustrative Examples of Bad and Good Practice Calls for Bids and Bids
}

\begin{abstract}
Good practice call for bids
(specific on tasks and skills, avoid personal information, moderately concrete, avoid being affectively intense)

$\mathrm{Hi}$, I am a Fitness Trainer and need help with building my website to showcase my mixed services and home workouts. I need a website designer who can design a WordPress website using a WordPress premium theme. The theme and examples will be provided, but you should also know about WordPress and optimize. You should have got very good creative skills but know how to design for web and also know how to include calls to actions within a good design. The website should be complete within 2 weeks. Please see the suggested payment and state your asking price for the entire project not per hour. Looking forward to hearing from you. Gary
\end{abstract}

\section{Bad practice call for bids}

(not specific on tasks and skills)

$\mathrm{Hi}$, need a website to showcase the full range of my fitness workouts. Job is 14 days, looking forward to your bid.

\section{Bad practice call for bids}

(too much personal information)

Hi, I am a Fitness Trainer with a lot of experience running workouts. I have been creating my own classes for almost 10 years now. Clients tend to especially love my classes on strength and flexibility. Now I need help setting up my website to showcase my services and home workouts. I need a website designer who can design a WordPress website using a WordPress premium theme. The theme and examples will be provided, but you should also know about WordPress and optimize. You should have got very good creative skills but know how to design for web and also know how to include calls to actions within a good design. The website should be complete within 2 weeks. Please see the suggested payment and state your asking price for the entire project not per hour. Looking forward to hearing from you. Gary

\section{Bad practice call for bids}

(not concrete enough)

$\mathrm{Hi}$, I provide certified, all-rounder fitness exercises and I seek help with establishing my interactive website. I require a professional who is savvy in configuring a stylish website employing a premium theme. I will impart the exposition but you should be cognizant about WordPress and reinvigorate. You should have got very good creative skills but know how to design for web and also know how to include calls to actions within a good design. The website should be complete within 2 weeks. Please see the suggested payment and state your asking price for the entire project not per hour. Looking forward to hearing from you. Gary

\section{Bad practice call for bids}

(too affectively intense)

$\mathrm{Hi}$, I am a super enthusiastic Fitness Trainer and need help with building an outstanding website to showcase my excellent services and home workouts. I need an open-minded website designer who is excited about designing a WordPress website using a WordPress premium theme. I have created a fantastic theme but you should be confident and eager about WordPress and help optimize. You should have got very good creative skills but know how to design for web and also know how to include calls to actions within a good design. The website should be complete within 2 weeks. Please see the suggested payment and state your asking price for the entire project not per hour. Looking forward to hearing from you. Gary

\section{Good practice bid ( directed to the good practice call for bids)}

(mimic task description, exceed little provision of personal information, exceed concreteness, mimic affective intensity) Hi Gary, I am happy to help you with your fitness website development and design.

I am a WordPress Freelancer with 15 years of work experience. I have worked on several similar projects, designing websites using a WordPress including premium themes and I can deliver to a tight schedule.

Website content that I produce will be creative and include original designs.

If you choose me for your website project, I would be very happy to discuss this further and get started for you as soon as possible. Thanks! Peter

\section{Bad practice bid ( directed to the good practice call for bids)}

(less specific on tasks and skills, less personal information, less concrete, exceeding affective intensity)

Dear Sir, would love to work for you. I have great skills and plenty of fantastic experience in creating relevant websites. I am an enthusiastic designer and expert in Web development. The content will be creative and fun, attractive, and thoughtful. If you award me the project, I'd be very happy to discuss this further and get started for you as soon as possible. Thanks! Peter 


\section{References for the Web Appendix}

Adjei, Mavis T., Stephanie M. Noble, and Charles H. Noble (2010), "The Influence of C2C Communications in Online Brand Communities on Customer Purchase Behavior," Journal of the Academy of Marketing Science, 38 (5), 634-653.

Agarwal Sanjeev and R. Kenneth Teas (2001), "Perceived Value: Mediating Role of Perceived Risk," Journal of Marketing Theory and Practice, 9 (4), 1-14.

Agnihotri, Raj, Adam Rapp and Kevin Trainor (2009), "Understanding the Role of Information Communication in the Buyer-Seller Exchange Process: Antecedents and Outcomes," Journal of Business \& Industrial Marketing, 24 (7), 474-86.

Ahearne, Michael, Ronald Jelinek and Eli Jones (2007), "Examining the Effect of Salesperson Service Behavior in a Competitive Context," Journal of the Academy of Marketing Science, 35, 603-16.

Anderson, James C. and James A. Narus (1990), "A Model of Distributor Firm and Manufacturer Firm Working Partnerships," Journal of Marketing, 54 (1), 42-58.

Anderson, Erin, Leonard M. Lodish, and Barton A. Weitz (1987), "Resource Allocation Behavior in Conventional Channels," Journal of Marketing Research, 24 (1), 85-97.

Barasch, Alixandra and Jonah Berger (2014), "Broadcasting and Narrowcasting: How Audience Size Affects What People Share," Journal of Marketing Research, 51 (3), 286-299.

Benoit, Kenneth, Paul Nulty, Pablo Barber, Kohei Watanabe, and Benjamin Lauderdale (2018), Quantitative Analysis of Textual Data, https://cran.r-project.org/web/packages/quanteda/.

Berger, Charles R., and Richard J. Calabrese (1975), "Some Explorations in Initial Interaction and Beyond: Toward a Developmental Theory of Interpersonal Communication," Human Communication Research, 1 (2), 99-112.

Bialaszewski, Dennis, and Michael Giallourakis (1985), "Perceived Communication Skills and Resultant Trust Perceptions within the Channel of Distribution," Journal of the Academy of Marketing Science, 13 (2), 206-17.

Brysbaert, Marc, Amy Beth Warriner, and Victor Kuperman (2014), "Concreteness Ratings for 40 Thousand Generally Known English Word Lemmas," Behavior Research Methods, 46 (3), 904-911.

Cannon, Joseph P. and Christian Homburg (2001), "Buyer-Supplier Relationships and Customer Firm Costs," Journal of Marketing, 65 (1), 29-43.

Comstock, Jamie and Gary Higgins (1997), “Appropriate Relational Messages in Direct Selling Interaction: Should Salespeople Adapt to Buyers' Communication Style?” The Journal of Business Communication, 34 (4), 401-18. 
Dalya, Shawn P. and Prithwiraj Nath (2005), "Reverse Auctions for Relationship Marketers," Industrial Marketing Management 34 (2), 157-166.

Dion, Paul A., and Elaine M. Notarantonio (1992), "Salesperson Communication Style: The Neglected Dimension in Sales Performance," Journal of Business Communication, 29 (1), 63-77.

Edwards, Jeffrey R. and Mark E. Parry (1993), “On the Use of Polynomial Regression Equations as an Alternative to Difference Scores in Organizational Research," Academy of Management Journal, 36 (6), 1577-1613.

Fugger, Nicolas, Elena Katok, and Achim Wambach (2019), “Trust in Procurement Interactions," Management Science, 65 (11), 5110-5127.

Grewal, Dhruv, Jerry Gotlieb, and Howard Marmorstein (1994), “The Moderating Effects of Message Framing and Source Credibility on the Price-perceived Risk Relationship," Journal of Consumer Research, 21 (1), 145-153.

Gudykunst, William B and Tsukasa Nishida (2001), “Anxiety, Uncertainty, and Perceived Effectiveness of Communication across Relationships and Cultures," International Journal of Intercultural Relations, 25 (1), 55-71.

Guiltnan, Joseph P., Ismail B. Rejab and William C. Rodgers (1980), "Factors Influencing Coordination in a Franchise Channel," Journal of Retailing, 56 (3), 42-58.

Hamilton, Mark A. and John E. Hunter (1998), "The Effect of Language Intensity on Receiver Evaluations of Message, Source, and Topic," Persuasion: Advances through Metaanalysis, 99-138.

Hamilton, Mark A. and Becky L. Stewart (1993), "Extending an Information Processing Model of Language Intensity Effects," Communication Quarterly, 41(2), 231-246.

Harris, Michael M., Frederik Anseel, and Filip Lievens (2008), "Keeping up with the Joneses: A Field Study of the Relationships among Upward, Lateral, and Downward Comparisons and Pay Level Satisfaction," Journal of Applied Psychology 93 (3), 665-673.

Herhausen, Dennis, Ludwig, Stephan, Grewal, Dhruv, Wulf, Jochen, \& Schögel, Marcus (2019), "Detecting, Preventing, and Mitigating Online Firestorms in Brand Communities," Journal of Marketing, 83 (3), 1-21.

Homburg, Christian, Annette Giering and Ajay Menon (2003), "Relationship Characteristics as Moderators of the Satisfaction-Loyalty Link: Findings in a Business-to-Business Context," Journal of Business to Business Marketing, 10 (3), 35-62.

Homburg, Christian, Laura Ehm, and Martin Artz (2015), "Measuring and Managing Consumer Sentiment in an Online Community Environment," Journal of Marketing Research, 52 (5), 629-641. 
Homburg, Christian, Harley Krohmer, Joseph P. Cannon, and Ingo Kiedaisch (2002), "Customer Satisfaction in Transnational Buyer-Supplier Relationships," Journal of International Marketing, 10 (4), 1-29.

Homburg, Christian, Michael Müller, and Martin Klarmann (2011), “When Does Salespeople's Customer Orientation Lead to Customer Loyalty? The Differential Effects of Relationship and Functional Customer Orientation," Journal of the Academy of Marketing Science, 39, 795-812.

Hong, Yili, and Paul A. Pavlou (2017), “On Buyer Selection of Service Providers in Online Outsourcing Platforms for IT Services,” Information Systems Research, 28 (3), 547-562.

Horton, John J. (2019), "Buyer Uncertainty about Seller Capacity: Causes, Consequences, and a Partial Solution”, Management Science, 65 (8), 3518-3540.

Horton, John J., and Ramesh Johari (2018), "Buyer Signaling Improves Matching: Evidence from a Field Experiment," Working Paper, [available at SSRN 3245704].

Hossain, Mehdi T. and Lawrence B. Chonko (2018), "Relational Communication and Illusionary Loyalty: Moderating Role of Self-Construal," Industrial Marketing Management, 69, 22134.

Hung, Kuang-Peng and Chung-Kuang Lin (2013), "More Communication is Not Always Better? The Interplay Between Effective Communication and Interpersonal Conflict in Influencing Satisfaction," Industrial Marketing Management, 42, 1223-32.

Ireland, Molly E., Richard B. Slatcher,Paul W. Eastwick, Lauren E. Scissors, Eli J. Finkeland James W. Pennebaker (2011), "Language Style Matching Predicts Relationship Initiation and Stability," Psychological Science, 22 (1), 39-44.

Jansen, Karen J. and Amy L. Kristof-Brown (2005), "Marching to the Beat of a Different Drummer: Examining the Impact of Pacing Congruence," Organizational Behavior and Human Decision Processes, 97 (2), 93-105.

Jaramillo, Fernando, Douglas B. Grisaffe, Lawrence B. Chonko, and James A. Roberts (2009), "Examining the Impact of Servant Leadership on Salesperson's Turnover Intention," Journal of Personal Selling \& Sales Management, 29 (4), 351-365.

Joshi, Ashwin W. (2009), “Continuous Supplier Performance Improvement: Effects of Collaborative Communication and Control," Journal of Marketing, 73 (1), 133-50.

Kim, Kihyun H. and V. Kumar (2018), "The Relative Influence of Economic and Relational Direct Marketing Communications on Buying Behavior in Business-to-Business Markets," Journal of Marketing Research, 55 (1), 48-68.

Kokkodis, Marios and Panagiotis, G. Ipeirotis (2016), "Reputation Transferability in Online Labor Markets," Management Science, 62 (6), 1687-1706. 
Kozlenkova, Irina V., Robert W. Palmatier, Eric Fang, Bangming Xiao, and Minxue Huang (2017), “Online Relationship Formation,” Journal of Marketing, 81 (3), 21-40.

Kramer, Michael W., Rebecca J. Meisenbach, and Glenn J. Hansen (2013), "Communication, Uncertainty, and Volunteer Membership." Journal of Applied Communication Research, 41 (1), 18-39.

Krippendorff, Klaus (2013), Content Analysis: An Introduction to Its Methodology, Thousand Oaks, CA: Sage.

Krishnan, Balaji C., Abhijit Biswas, and Richard G. Netemeyer (2006), "Semantic Cues in Reference Price Advertisements: The Moderating Role of Cue Concreteness," Journal of Retailing, 82 (2), 95-104.

Kronrod, Ann and Shai Danziger (2013), "Wii Will Rock You!” The Use and Effect of Figurative Language in Consumer Reviews of Hedonic and Utilitarian Consumption," Journal of Consumer Research, 40 (4), 726-739.

Kumar, V. and Rajkumar Venkatesan (2005), "Who are the Multichannel Shoppers and how do they Perform?: Correlates of Multichannel Shopping Behavior," Journal of Interactive Marketing, 19 (2), 44-62.

Loughran, Tim, and Bill McDonald (2011), "When is a Liability not a Liability? Textual Analysis, Dictionaries, and 10-Ks," Journal of Finance, 66 (1), 35-65.

Ludwig, Stephan, Ko de Ruyter, Mike Friedman, Elisabeth C. Brüggen, Martin Wetzels, and Gerard Pfann (2013), "More Than Words: The Influence on Affective Content and Linguistic Style Matches in Online Reviews on Conversion Rates," Journal of Marketing, 77 (1), 87-103.

Ma, Liye, Baohong Sun and Sunder Kekre (2015), "The Squeaky Wheel Gets the Grease-An Empirical Analysis of Customer Voice and Firm Intervention on Twitter," Marketing Science, 34 (5), 627-645.

McFarland, Richard G., Goutam N. Challagalla, and Tasadduq A. Shervani (2006), "Influence Tactics for Effective Adaptive Selling," Journal of Marketing, 70 (4), 103-17.

Menguc, B., Auh, S., Katsikeas, C. S., and Jung, Y. S. (2016), "When does (mis) fit in Customer Orientation Matter for Frontline Employees' Job satisfaction and Performance?" Journal of Marketing, 80(1), 65-83.

Mohr, Jakki J., Robert J. Fisher and John R. Nevin (1996), “Collaborative Communication in Interfirm Relationships: Moderating Effects of Integration and Control," Journal of Marketing, 60 (3), 103-115.

Mohr, Jakki J., and Ravipreet S. Sohi (1995), "Communication Flows in Distribution Channels: Impact on Assessments of Communication Quality and Satisfaction," Journal of Retailing, $71(4), 393-416$. 
Moon, Sangkil, and Wagner A. Kamakura (2017), "A Picture is Worth a Thousand Words: Translating Product Reviews into a Product Positioning Map," International Journal of Research in Marketing, 34 (1), 265-285.

Morgan, Robert M., and Shelby D. Hunt (1994), "The Commitment-Trust Theory of Relationship Marketing," Journal of Marketing, 58 (3), 20-38.

Montoya, Amanda K., and Andrew F. Hayes (2017), "Two-condition Within-participant Statistical Mediation Analysis: A Path-analytic Framework," Psychological Methods, 22 (1), 6 .

Mullins, R. R., Ahearne, M., Lam, S. K., Hall, Z. R., and Boichuk, J. P. (2014), "Know your Customer: How Salesperson Perceptions of Customer Relationship Quality Form and Influence Account Profitability," Journal of Marketing, 78(6), 38-58.

Murphy, Micah and C.M. Sashi (2018), "Communication, Interactivity, and Satisfaction in B2B Relationships," Industrial Marketing Management, 68, 1-12.

Nguyen, Hang T., and Malika Chaudhuri (2018), "Making New Products Go Viral and Succeed," International Journal of Research in Marketing, 36 (1), 39-62.

Niederhoffer, Kate G., and James W. Pennebaker (2002), "Linguistic Style Matching in Social Interaction," Journal of Language and Social Psychology, 21(4), 337-360.

Ostrom, Amy and Dawn lacobucci (1995), "Consumer Trade-Offs and the Evaluation of Services," Journal of Marketing, 59 (1) 17-28.

Packard, Grant, Sarah G. Moore and Brent McFerran (2018), “(I’m) Happy to Help (You): The Impact of Personal Pronoun Use in Customer-Firm Interactions," Journal of Marketing Research, 55 (4), 541-555.

Palmatier, Robert W., Rajiv P. Dant, and Dhruv Grewal (2007), “A Comparative Longitudinal Analysis of Theoretical Perspectives of Interorganizational Relationship Performance," Journal of Marketing, 71 (4), 172-94.

Palmatier, Robert W., Rajiv P. Dant, Dhruv Grewal, and Kenneth R. Evans (2006), "Factors Influencing the Effectiveness of Relationship Marketing: A Meta-Analysis," Journal of Marketing, 70 (4), 172-94.

Pennebaker, James W., and Lori D. Stone. (2003), "Words of Wisdom: Language Use Over the Life Span," Journal of Personality and Social Psychology, 85 (2), 291-301.

Pitt, Christine, Michael Mulvey, and Jan Kietzmann (2018), Quantitative Insights from Online Qualitative Data: An Example from the Health Care Sector. Psychology \& Marketing, 35 (12), 1010-1017. 
Ravichander, Abhilasha and Alan Black (2018), "An Empirical Study of Self-Disclosure in Spoken Dialogue Systems," Proceedings of the SIGDIAL 2018 Conference, pages 253263, Melbourne, Australia, 12-14 July.

Rindfleisch, Aric and Jan B. Heide (1997), “Transaction Cost Analysis: Past, Present, and Future Applications," Journal of Marketing, 61 (4), 30-54.

Rocklage, Matthew D., and Russell H. Fazio (2015), "The Evaluative Lexicon: Adjective Use as a Means of Assessing and Distinguishing Attitude Valence, Extremity, and Emotionality," Journal of Experimental Social Psychology, 56 (1), 214-27.

Román, Sergio, and Pedro J. Martín (2008), “Changes in Sales Call Frequency: A Longitudinal Examination of the Consequences in the Supplier-Customer Relationship," Industrial Marketing Management, 37 (5), 554-564.

Schmitz, Christian, Maximilian Friess, Sascha Alavi, Johannes Habel (2020), "Understanding the Impact of Relationship Disruptions," Journal of Marketing, 84 (1), 66-87.

Shanock, Linda R., Baran, Benjamin E., Gentry, William A., Pattison, Stacy C., and Heggestad, Eric D. (2010), "Polynomial Regression with Response Surface Analysis: A Powerful Approach for Examining Moderation and Overcoming Limitations of Difference Scores," Journal of Business and Psychology, 25(4), 543-554.

Sicilia, Maria, and Salvador Ruiz (2010), "The Effect of Web-based Information Availability on Consumers' Processing and Attitudes," Journal of Interactive Marketing 24 (1), 31-41.

Singh, Sunil K., Detelina Marinova, and Jagdip Singh (2020), "Business-to-Business ENegotiations and Influence Tactics," Journal of Marketing, 84 (2) 47-68.

Singh, Jagdip and Deepak Sirdeshmukh (2000), “Agency and Trust Mechanisms in Consumer Satisfaction and Loyalty Judgments," Journal of the Academy of Marketing Science, 28 (1), 150-67.

Sonnier, Garrett P., Leigh McAlister and Oliver J. Rutz (2011), “A Dynamic Model of the Effect of Online Communications on Firm Sales,” Marketing Science, 30 (4), 702-716.

Stone, Philip J., and Earl B. Hunt (1963), "A Computer Approach to Content Analysis: Studies Using the General Inquirer System," In Proceedings of the May 21-23, 1963, Spring Joint Computer Conference, 241-256.

Tan, Pang-Ning and Michael Steinbach and Vipin Kuma (2006), "Introduction to Data Mining". Pearson Education, India.

Timoshenko, Artem and John R. Hauser (2019), "Identifying Customer Needs from UserGenerated Content," Marketing Science, 38 (1), 1-20.

Toma, Catalina L., and Jeffrey T. Hancock (2012), "What Lies Beneath: The Linguistic Traces of Deception in Online Dating Profiles," Journal of Communication, 62 (1), 78-97. 
Van Laer, Tom, Jennifer Edson Escalas, Stephan Ludwig, and Ellis A. Van den Hende (2018), "What Happens in Vegas Stays on TripAdvisor? Computerized Analysis of Narrativity in Online Consumer Reviews," Journal of Consumer Research, 46 (2), 267-85.

Venkatesh, R., Ajay K. Kohli, and Gerald Zaltman (1995), "Influence Strategies in Buying Centers," Journal of Marketing, 59 (October), 71-82.

Villarroel Ordenes, Francisco, Stephan Ludwig, Ko de Ruyter, Dhruv Grewal, and Martin Wetzels (2017), "Unveiling What is Written in the Stars: Analyzing Explicit, Implicit, and Discourse Patterns of Sentiment in Social Media," Journal of Consumer Research, 43 (6), 875-94.

Villaroel Ordenes, Francisco, Dhruv Grewal, Stephan Ludwig, Ko De Ruyter, Dominik Mahr, Martin Wetzels, and Praveen Kopalle (2018), "Cutting Through Content Clutter: How Speech and Image Acts Drive Consumer Sharing of Social Media Brand Messages," Journal of Consumer Research, 45 (5) 988-1012.

Wang, Sijun, Sharon E. Beatty, and Jeanny Liu (2012), "Employees' Decision Making in the Face of Customers' Fuzzy Return Requests," Journal of Marketing, 76 (6), 69-86.

Wheeless, Lawrence R (1976), "Self-disclosure and Interpersonal Solidarity: Measurement, Validation, and Relationships," Human Communication Research, 3 (1), 47-61.

Yin, Dezhi, Samuel D. Bond, and Han Zhang (2017), "Keep Your Cool or Let it Out: Nonlinear Effects of Expressed Arousal on Perceptions of Consumer Reviews," Journal of Marketing Research, 54 (3), 447-463.

Zhang, Jonathan, Oded Netzer, and Asim Ansari (2014), "Dynamic Targeted Pricing in B2B Relationships," Marketing Science, 33 (3), 317-37.

Zhang, Yuchi, Wendy W. Moe, and David A. Schweidel (2017), "Modeling the Role of Message Content and Influencers in Social Media Rebroadcasting," International Journal of Research in Marketing, 34 (1), 100-119. 